\title{
WestVirginiaUniversity
}

THE RESEARCH REPOSITORY @ WVU

Graduate Theses, Dissertations, and Problem Reports

2006

\section{Democracy by any other name just isn't the same}

\author{
Clarissa Estep \\ West Virginia University
}

Follow this and additional works at: https://researchrepository.wvu.edu/etd

\section{Recommended Citation}

Estep, Clarissa, "Democracy by any other name just isn't the same" (2006). Graduate Theses,

Dissertations, and Problem Reports. 2407.

https://researchrepository.wvu.edu/etd/2407

This Dissertation is protected by copyright and/or related rights. It has been brought to you by the The Research Repository @ WVU with permission from the rights-holder(s). You are free to use this Dissertation in any way that is permitted by the copyright and related rights legislation that applies to your use. For other uses you must obtain permission from the rights-holder(s) directly, unless additional rights are indicated by a Creative Commons license in the record and/ or on the work itself. This Dissertation has been accepted for inclusion in WVU Graduate Theses, Dissertations, and Problem Reports collection by an authorized administrator of The Research Repository @ WVU.

For more information, please contact researchrepository@mail.wvu.edu. 
Democracy By Any Other Name Just Isn’t the Same

\author{
Clarissa Estep
}

Dissertation submitted to the Eberly College of Arts and Sciences at West Virginia University

in partial fulfillment of the requirements

for the degree

Doctor of Philosophy

in

Political Science

\author{
Jamie Elizabeth Jacobs, Ph.D., Committee Chair Person \\ Joe Hagan, Ph.D. \\ Robert Duval, Ph.D. \\ Scott Crichlow, Ph.D. \\ William Trumbell, Ph.D. (Economics) \\ Department of Political Science \\ Morgantown, West Virginia \\ 2006
}

Key Words: Democratization, Democratic Peace, Democratization and War, Political Institutions

Copyright 2006 Clarissa Estep 


\section{Abstract \\ Democracy By Any Other Name Just Isn’t the Same \\ Clarissa Estep}

Democracy has been one of the fundamental achievements in the post-World War II era. Because evidence of the democratic peace exists, illiberal states are being pressured to form democracies. However, democratic consolidation, on which the democratic peace relies, remains a persistent problem of the Third World. Thus, the paradox remains that democratizing states are prone to violence which undermines peace and security. Considering that the majority of states in the international community are mixed regimes, or anocracies, this poses a problem for reducing interstate and intrastate conflict in these regimes. It is not enough to declare success with the establishment of electoral democracies; rather it is necessary to identify the political institutions that create mature democracies which validate the democratic peace.

This research seeks to explain the relationship between political institutions, the level of democratization, and conflict in anocracies. Using a top-down approach to quantitatively test the years 1974 through 2000, this research examines the role of political institutions, such as constitutional structure, press freedom, free and fair elections, military accountability, as well as the legitimacy of the executive, legislative, and judicial branches. With theoretical grounding in literature on democratizing states (e.g. Snyder, Mansfield and Snyder), the waves of democracy (Diamond), political decay (Huntington), political development, and the democratic peace, this research suggests that there is a threshold effect regarding political institutions which must be established before democracy can be consolidated and the conflict levels can be reduced in democratizing states. 


\section{Acknowledgements}

There are several people that have been instrumental in helping me to finish my dissertation. First, I would like to thank my husband, Paul, for his constant patience, support, and love. He provided the time for me to finish my dissertation. I could not have done this without him. Second, I would like to thank my parents, Hoye and Shirley Carr, and brother, Eli Carr, for their unconditional love, unwavering support, and constant encouragement. This accomplishment is as much theirs as it is mine. Finally, I want to thank Walter and Lady Grey, my four-legged friends, for their feline antics and needed distractions.

I want to thank several faculty members for their assistance throughout the process of writing my dissertation. First, words cannot express my gratitude for Dr. Jamie Jacobs, my dissertation chair. She has provided me with indispensable guidance, encouragement, and friendship throughout the dissertation process and the years of graduate school. I also want to thank the other members of my committee for their advice and council: Dr. Joe Hagan, Dr. Bob Duval, Dr. Scott Crichlow, and Dr. Bill Trumbull. Dr. Bob Duval and Dr. Dave Hauser provided invaluable assistance in the shaping of my quantitative chapters. Also, it is important to thank the faculty, staff, and graduate students of the Department of Political Science for providing a pleasant atmosphere in which to pursue a degree.

Finally, I want to thank Dr. Heather Frederick and Clay Smith for their subtle reminders that my dissertation needed finishing. 


\section{Table of Contents}

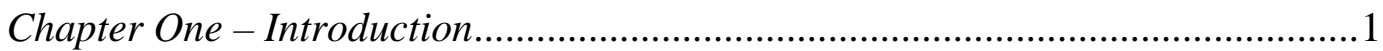

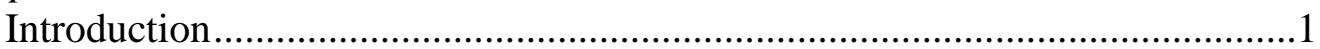

The Outline of this Dissertation ............................................................

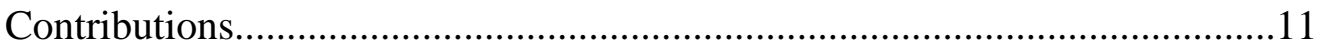

Chapter Two - Optimism versus Pessimism: The Democratic Peace versus Democratization and War ...............................................................................12

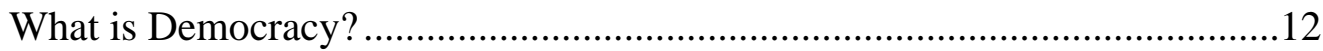

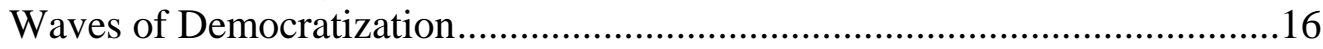

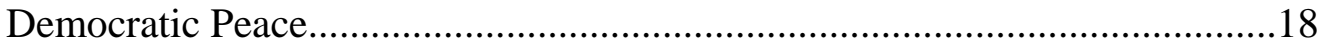

Democratization and Conflict .................................................................21

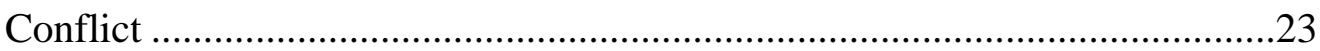

Political Consolidation and Political Decay ...............................................25

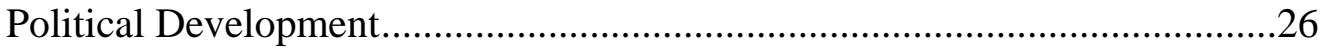

Chapter Three - The Institutional Threshold Theory ..........................................30

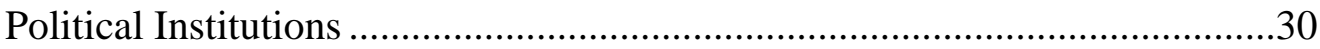

Governmental versus Intermediary Institutions.......................................36

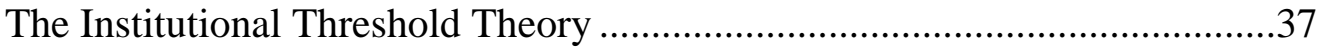

Chapter Four - Research Design ..........................................................41

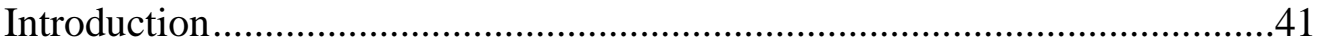

Questions and Hypotheses ......................................................................44

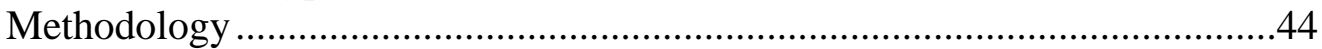

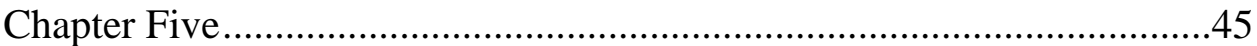

Chapter Six............................................................................4

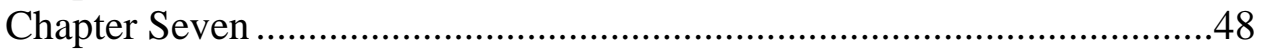

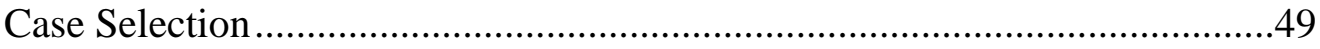

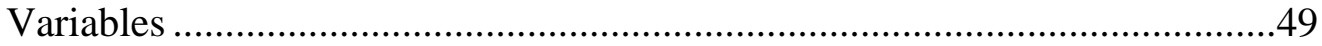

Dependent Variables .....................................................................49

Independent Variables .........................................................................52

Control Variables ............................................................................59

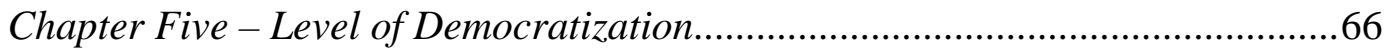

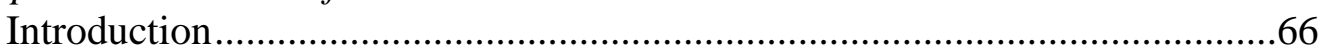

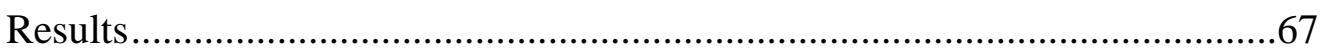

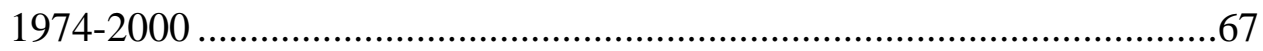

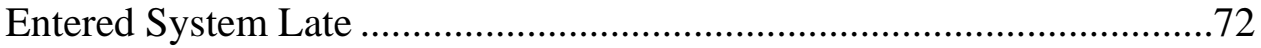

Rule of Law, Bureaucratic Quality ....................................................76

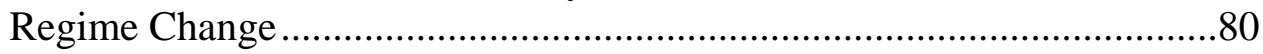

Alternative Models..................................................................................83

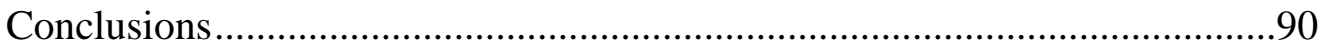


Chapter Six - Militarized Interstate Disputes ......................................................98

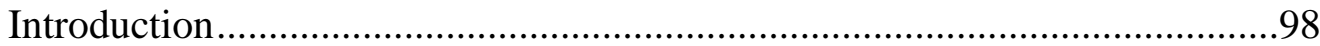

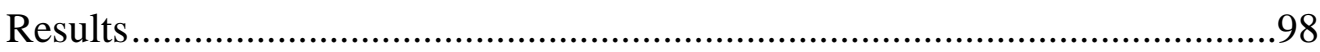

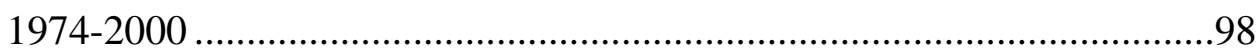

Entered System Late …………………………………….....................103

Rule of Law, Bureaucratic Quality ……………………........................107

Regime Change ...................................................................................112

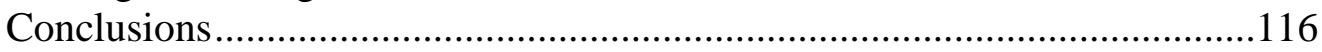

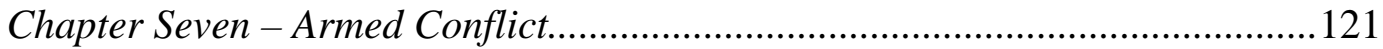

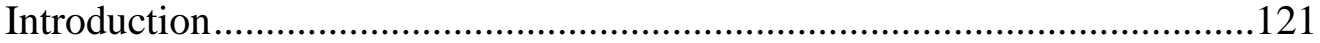

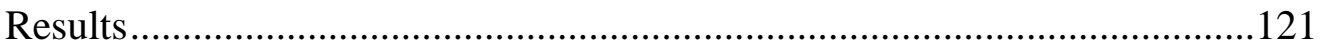

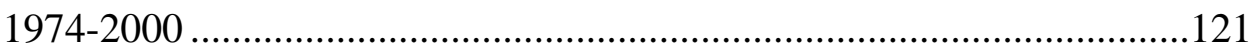

Entered System Late ...........................................................................127

Rule of Law, Bureaucratic Quality .....................................................131

Regime Change ...............................................................................135

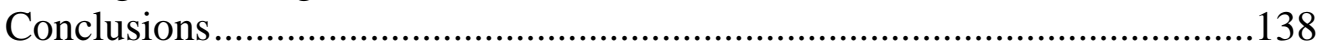

Chapter Eight - Conclusions ..............................................................................144

Examination of Research Questions and Hypotheses......................................144

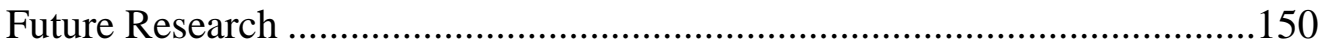

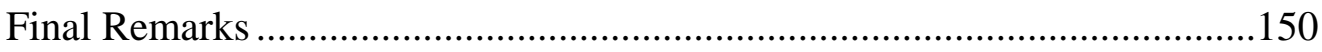

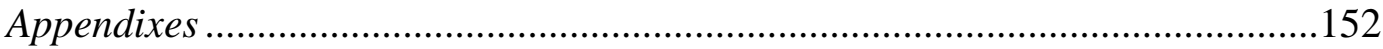

Appendix 1. Classification of Countries Based Upon Their Level of

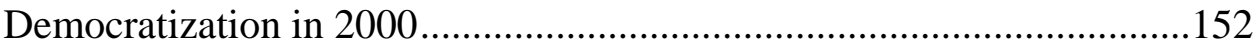

Appendix 2. Countries of Interest................................................................154

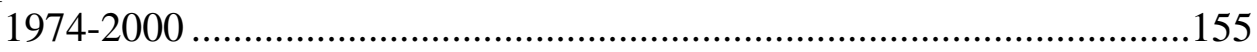

Entered System Late ...........................................................................156

Rule of Law, Bureaucratic Quality …………………….......................157

Regime Change .................................................................................158

Appendix 3. Institutional Index Recoding Scheme ........................................159

Appendix 4. Freedom House Democracy Indicator Outputs............................164

Appendix 5. Change in the Level of Democratization Outputs......................173

Appendix 6. Coding Scheme for the Ordering of the Governmental and Intermediary Institutions .........................................................................182

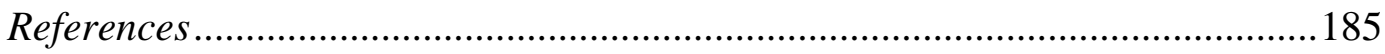




\section{Lists of Maps}

Map 1-1. Countries of Interest, Level of Democratization, 2000 Status .................7 


\section{List of Figures}

Figure 1-1. Level of Democratization in 2000................................................

Figure 1-2. Regional Classification for Countries of Interest..............................9

Figure 3-1. The Institutional Threshold Theory ...............................................40

Figure 4-1. Classification of Governmental and Intermediary Institutions ...........44

Figure 4-2: Formulas for Time Series Panel Regression Models in Chapter 5 .....46

Figure 4-3: Formulas for Time Series Panel Logit Models in Chapter 6 ..............47

Figure 4-4: Formulas for Time Series Panel Regression Models in Chapter 7 .....48

Figure 5-1. Performance of the Institutional Index

Level of Democratization ..........................................................91

Figure 5-2. Performance of the Component Variables of the Institutional Index Level of Democratization ..................................................................93

Figure 5-3. Performance of the Institutional Index

Change in the Level of Democratization .........................................94

Figure 5-4. Performance of the Component Variables of the Institutional Index Change in the Level of Democratization

Figure 5-5. Performance of the Institutional Index

Freedom House Democracy Indicator

Figure 5-6. Performance of the Component Variables of the Institutional Index

Freedom House Democracy Indicator

Figure 6-1. Level of Democratization Indicator

Militarized Interstate Disputes.

Figure 6-2. Performance of the Institutional Index

Militarized Interstate Disputes.

Figure 6-3. Performance of the Component Variables of the Institutional Index

Militarized Interstate Disputes

Figure 7-1. Level of Democratization Indicator

Armed Conflict 
Figure 7-2. Performance of the Institutional Index

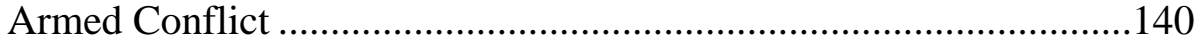

Figure 7-3. Performance of the Component Variables of the Institutional Index

Armed Conflict ..........................................................................142 


\section{Lists of Tables}

Table 5-1. Correlation Matrix between the Level of Democratization and the Institutional Index, 1974 through 2000.

Table 5-2. Time Series Panel Regression for the Level of Democratization 1974 through 2000 Full Model

Table 5-3. Time Series Panel Regression for Level of Democratization 1974 through 2000 Institution Variables

Table 5-4. Correlation Matrix between the Level of Democratization and the Institutional Index, Entered System Late.... .73

Table 5-5. Time Series Panel Regression for Level of Democratization Entered System Late Full Model .74

Table 5-6. Time Series Panel Regression for Level of Democratization Entered System Late Institution Variables .76

Table 5-7. Correlation Matrix between the Level of Democratization and the Institutional Index, Rule of Law / Bureaucratic Quality..... .77

Table 5-8. Time Series Panel Regression for Level of Democratization Rule of Law / Bureaucratic Quality Full Model

Table 5-9. Time Series Panel Regression for Level of Democratization Rule of Law / Bureaucratic Quality Institution Variables .

Table 5-10. Correlation Matrix between the Level of Democratization and the Institutional Index, Regime Change 80

Table 5-11. Time Series Panel Regression for Level of Democratization Regime Change Full Model

Table 5-12. Time Series Panel Regression for Level of Democratization Regime Change Institution Variables

Table 5-13. Time Series Panel Regression (with a 3 year moving average) for the Freedom House Democracy Indicator (Full Models)............85

Table 5-14. Time Series Panel Regression (with a 3 year moving average) for the Freedom House Democracy Indicator (Institution Models)..86

Table 5-15. Time Series Panel Regression for the Change in the Level of Democratization (Full Models). 
Table 5-16. Time Series Panel Regression for the Change in the Level of Democratization (Institution Models).

Table 6-1. Time Series Panel Logit for Militarized Interstate Disputes 1974 through 2000 Full Model

Table 6-2. Predicted Outcomes for Militarized Interstate Disputes 1974 through 2000

Table 6-3. Time Series Panel Logit for Militarized Interstate Disputes 1974 through 2000 Institution Variables

Table 6-4. Time Series Panel Logit for Militarized Interstate Disputes Entered System Late Full Model

Table 6-5. Predicted Outcomes Militarized Interstate Disputes Entered System Late 106

Table 6-6. Time Series Panel Logit for Militarized Interstate Disputes Entered System Late Institution Variables

Table 6-7. Time Series Panel Logit for Militarized Interstate Disputes Rule of Law / Bureaucratic Quality Full Model

Table 6-8. Predicted Outcomes Militarized Interstate Disputes Rule of Law / Bureaucratic Quality..

Table 6-9. Time Series Panel Logit for Militarized Interstate Disputes Rule of Law / Bureaucratic Quality Institution Variables

Table 6-10. Time Series Panel Logit for Militarized Interstate Disputes Regime Change Full Model.

Table 6-11. Predicted Outcomes Militarized Interstate Disputes

Regime Change.

Table 6-12. Time Series Panel Logit for Militarized Interstate Disputes

Regime Change Institution Variables

Table 7-1. Time Series Panel Regression for Armed Conflict 1974 through 2000 Full Model

Table 7-2. Time Series Panel Regression for Armed Conflict 1974 through 2000 Institution Variables 
Table 7-3. Time Series Panel Regression for Armed Conflict

Entered System Late Full Model

Table 7-4. Time Series Panel Regression for Armed Conflict

Entered System Late Institution Variables

Table 7-5. Time Series Panel Regression for Armed Conflict

Rule of Law / Bureaucratic Quality Full Model.

Table 7-6. Time Series Panel Regression for Armed Conflict

Rule of Law / Bureaucratic Quality Institution Variables

Table 7-7. Time Series Panel Regression for Armed Conflict

Regime Change Full Model

Table 7-8. Time Series Panel Regression For Armed Conflict

Regime Change Institution Variables ................................................138

Table 8-1. Rankings of Governmental Institutions...............................................146

Table 8-2. Ranking of Intermediary Institutions..................................................147

Table 8-3. Rankings of Both Governmental and Intermediary Institutions..........147 


\section{List of Acronyms}

MID

COW

CINC

PEC

EUGene

MAR
Militarized Interstate Disputes

Correlates of War

Composite Index of National Capacity

Primary Energy Consumption

Expected Utility Generation and Data Management Program

Minorities at Risk 


\section{Chapter 1}

\section{Introduction}

The promotion of democracy has been a defining characteristic of the post-World War II era. It has been the focal point of American foreign policy, particularly in recent administrations. Even before the term “democratic peace” transcended the academic community, President Ronald Reagan, in a 1982 speech before the British Parliament, proposed a “campaign for democratic development” based upon the belief that “governments founded on a respect for individual liberty exercise 'restraint' and 'peaceful intentions' in their foreign policy” (Doyle 1986, p. 1151). More than a decade later, President Bill Clinton advocated that support for democratization would be a remedy to international war and civil conflict. In his 1994 State of the Union Address, President Clinton said, “(u)ltimately, the best strategy to ensure our security and to build a durable peace is to support the advance of democracy elsewhere” because “(d)emocracies don't attack each other...” President George W. Bush claimed in his Second Inaugural Address that "it is the policy of the United States to seek and support the growth of democratic movements and institutions in every nation...” In a speech before the United Nations General Assembly, President Bush declared,

The work of democracy is larger than holding a fair election; it requires building the institutions that sustain freedom. Democracy takes different forms in different cultures, yet all free societies have certain things in common. Democratic nations uphold the rule of law, impose limits on the power of the state, treat women and minorities as full citizens. Democratic nations protect private property, free speech and religious expression. Democratic nations grow in strength because they reward and respect the creative gifts of their people. And democratic nations contribute to peace and stability because they seek national greatness in the achievements of their citizens, not the conquest of their neighbors. 
The United States is not the only entity advocating democratization. Democracy promotion is also the goal of other Western democracies and international organizations such as the United Nations and European Union as "international dimensions of democratization moved to the center stage" (Grugel 2002, p. 116). "The creation of a global political economy and the emergence of global governance mechanisms generate pressures for democratization” (Grugel 2002, p. 116). With these developments, international organizations have begun to take an active role in the campaign for democracy.

According to Huntington, "the movement toward democracy (has taken) on the character of an almost irresistible global tide moving on from one triumph to the next” (1991, p. 21). This recent pressure for states to democratize is centered in the democratic peace, which is the quantitatively established theory that democracies rarely, if ever, wage war on other democracies. Recently successful elections in Iraq and Afghanistan and promising pro-democracy movements in Lebanon (although this fragile democracy is currently being tested), Egypt, Ukraine, Kyrgyzstan, Serbia, and other states suggest that the United States, other Western democracies, and international organizations are promoting a policy that will ultimately contribute to international peace. However, skeptics to the passivity of the democratic peace, namely Mansfield and Snyder, have provided a third, contradictory assumption to the optimism of the democratic peace. Mansfield and Snyder suggest that while the democratic peace holds for well-established democracies, states that are making the transition to democracy are more war prone, both internally and externally, than either democratic or authoritarian states and they will engage in conflict with either democracies or non-democracies. According to Mansfield 
and Snyder, recent examples of democratizing war are the disintegration process of Yugoslavia, Armenia versus Azerbaijan, Peru versus Ecuador, Ethiopia versus Eritrea, India versus Pakistan, internal conflict in Rwanda concerning the Hutus versus Tutsis, and the secessionist movements in East Timor and Chechnya (2005, pp. 4-6).

Contemporary democratizing states are often described with adjectives:

pseudodemocracy, semi-democracy, illiberal democracy, authoritarian democracy, quasi democracy, electoral democracy, and so on. These states are not mature or liberal democracies and they lack the characteristics that validate the democratic peace, upon which the recent democratization pressure lies. As this dissertation's title suggests, democracy by any other name just isn’t the same. According to Mansfield and Snyder, anocracies, or democratizing states, are more prone to violence, which undermines peace and security. Considering there is a "growing conviction that the expansion of democracy serves international peace and security” (Diamond 1995, p. 52), the international community should make more of an attempt to consolidate democracy as opposed to advancing pseudodemocracy.

The two literatures that dominate this research, the democratic peace and democratization and war, create a paradox for academics and policy-makers alike. Because of the democratic peace, the proliferation of democracy is a constructive force in world politics, yet the democratization process is inherently dangerous which only serves to aggravate the hostilities intrinsic in international relations. The end result is supposed to be cooperation between democracies, but before this can occur democratizing states are more at risk for heightened conflict. A major contribution of this dissertation is the introduction of the institutional threshold theory. The institutional threshold theory is an 
attempt to reconcile the optimism of the democratic peace with the pessimism of the democratization and war literature by discovering the necessary and sufficient political institutions needed to consolidate democracy and thus authenticate the democratic peace. By identifying the critical political institutions, states can focus on strengthening these institutions, thereby reducing the amount of time they spend within the inherently violent democratizing process, and more quickly move towards democratic consolidation and the cooperation associated with the democratic peace.

This research seeks to examine the relationship between political institutions, the level of democratization, and conflict in anocracies, which are democratizing states that exhibit traits of both authoritarian and democratic regimes. A significant body of scholarly research has been conducted concerning democratic consolidation and political institutions (Huntington 1991; Diamond 1999, 1996; Diamond, et. al. 1997; Mansfield and Snyder 2005, 2002, 1995; Linz 1990; Linz and Stepan 1997, 1996; etc.); however, this work does not provide a comprehensive empirical assessment of political institutions for anocracies. Using quantitative research for the time period 1974 through 2000, and introducing a political institutions threshold theory, this research attempts to provide a template concerning the political institutions that facilitate democratic consolidation, and by extension, the international peace and security that exists with the democratic peace.

In an effort to understand the reasons why some states are able to consolidate democracy and then enjoy the passivity that exists among democratic states, several research questions have been developed. Does the proliferation of democracy really contribute to world peace? Is democracy promotion a valuable policy tool to ensure world peace, or are the policy-makers inadvertently advancing conflict as suggested by 
Mansfield and Snyder? Which political institutions are necessary to ensure democratic consolidation and by extension prevent armed conflict through the validation of the democratic peace? Is there a difference between governmental institutions and intermediary institutions in democratic consolidation and the prevention of armed conflict $^{1}$ ? Similar to the threshold that exists for the gross national product and literacy rates, is there an institutional threshold necessary for states to democratize ${ }^{2}$ ?

In addition to the above questions, this dissertation tests three fundamental research questions. First, are states that focus on building strong political institutions more likely to consolidate democracy? Second, are states that focus on building strong political institutions more likely to avoid armed conflict? And finally, is there a difference between governmental and intermediary institutions in the process of democratic consolidation? These questions work in conjunction to identify those political institutions that play a critical role in the process of democratic consolidation, thereby creating mature democracies, which are not subject to armed conflict, and in turn validate the democratic peace. These questions are tested in Chapters Five, Six, and Seven.

Map 1-1 displays the countries of interest to this dissertation research. Based upon the coding rule for anocracies, or democratizing countries, 87 states qualify for inclusion in this research. The institutional, democratic, and conflictual attributes of theses countries will be statistically analyzed during the years 1974, which is the start of the Third Wave of democratization, through 2000. As the map indicates, the states are

\footnotetext{
${ }^{1}$ For a more detailed discussion regarding the differences between governmental and intermediary institutions, see the section titled Governmental versus Intermediary Institutions in Chapter Three and the section titled Research Questions and Hypotheses in Chapter Four.

${ }^{2}$ For a more detailed discussion regarding the gross national product and literacy rate thresholds, see the section titled Political Development in Chapter Two.
} 
located in the Global South or are countries in transition that were once affiliated with the Soviet Union. 


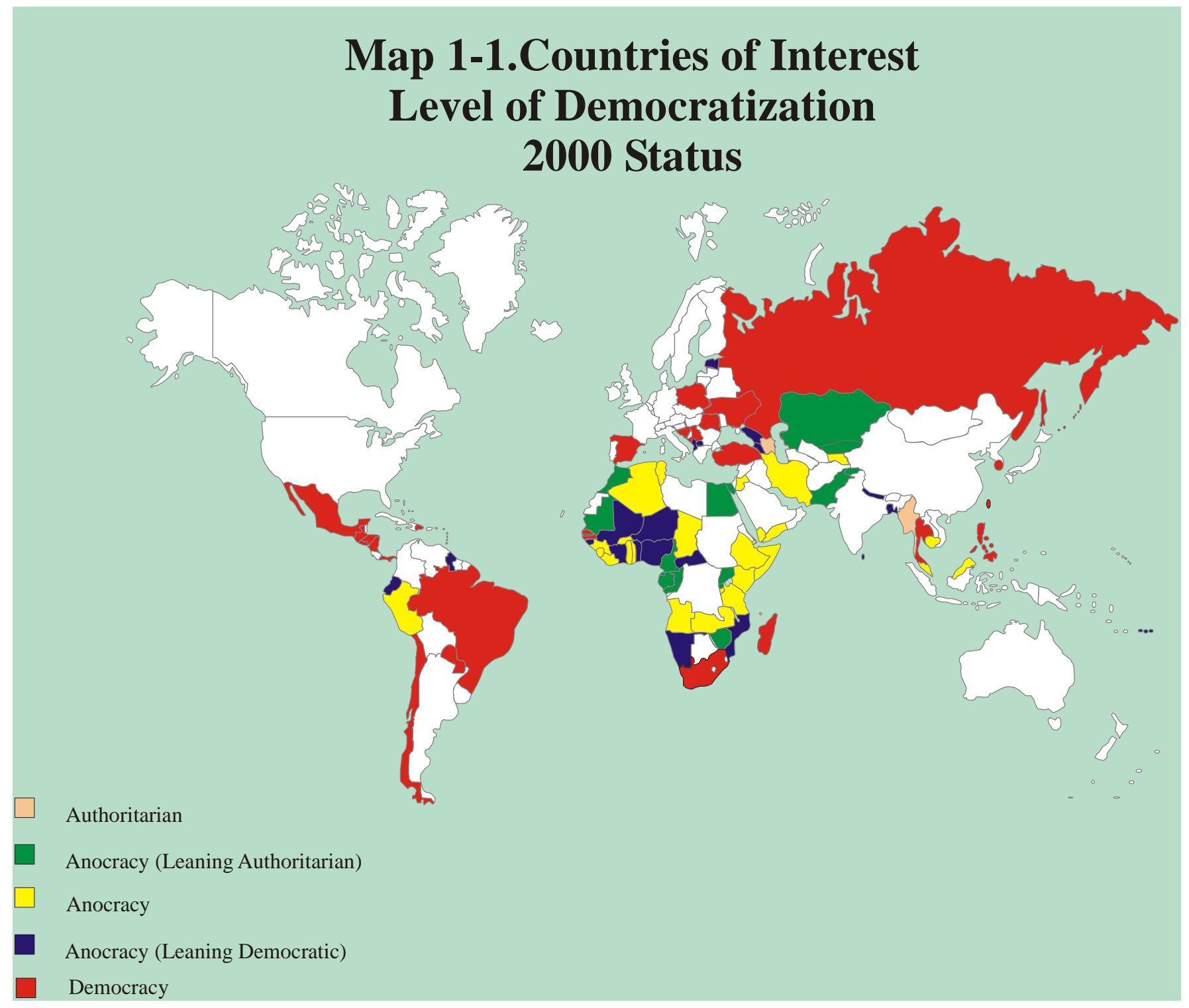


There are some positive and negative observations that can be drawn based upon the state's level of democratization in 2000. Unfortunately, as Figure 1-1 indicates, most states of interest to this research are still classified as anocracies, or states that exhibit characteristics of both authoritarian and democratic regimes, in 2000. This suggests that these countries are entrenched anocracies and are at a heightened risk for conflict through democratizing war. However, there are positive observations as well. The second and third most populous categories are democracy and anocracy leaning democratic. This means that these countries are not becoming entrenched anocracies; rather they are moving towards democratic consolidation. In addition, only $18 \%$ of the countries of interest have predominately authoritarian characteristics.

Figure 1-1. ${ }^{3}$ Level of Democratization in 2000

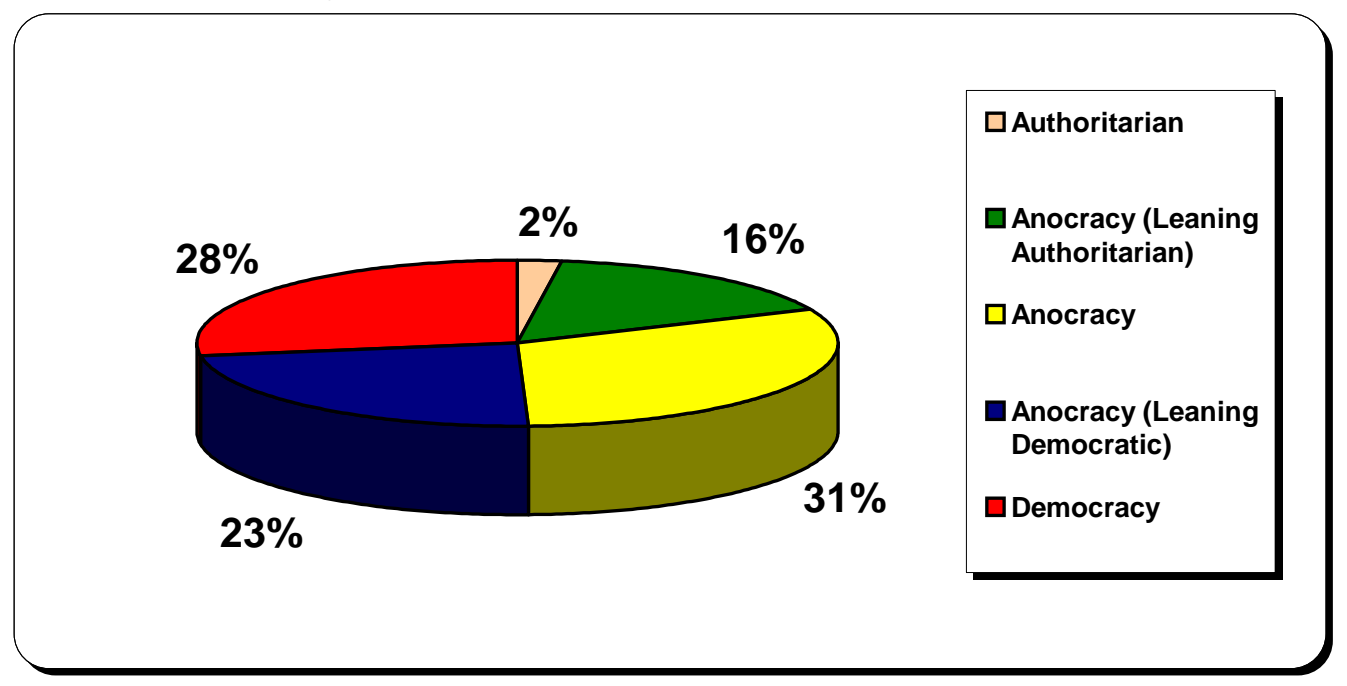

As previously stated, all of the countries of interest to this dissertation research are located in the Global South. Figure 1-2 denotes that nearly half of the 87 countries

\footnotetext{
${ }^{3}$ The state's Polity 2 score in 2000 determines their level of democratization. The Polity 2 score is a 21point scale ranging from -10 to +10 . The breakdown for classification in Map 1-1 and Figure 1-1 occurs as follows:

-10 to $-7=$ Authoritarian, -6 to $-4=$ Anocracy leaning Authoritarian, -3 to $+3=$ Anocracy, 4 to $6=$ Anocracy leaning Democratic, 7 to $10=$ Democracy. Appendix 1 contains a list of countries according to their classification.
} 
are located in Africa, with Asia, the Americas, and Europe making up the remaining percentages, respectively. Only one state from Oceania, Fiji, qualified for inclusion on the research.

Figure 1-2. Regional Classification for Countries of Interest

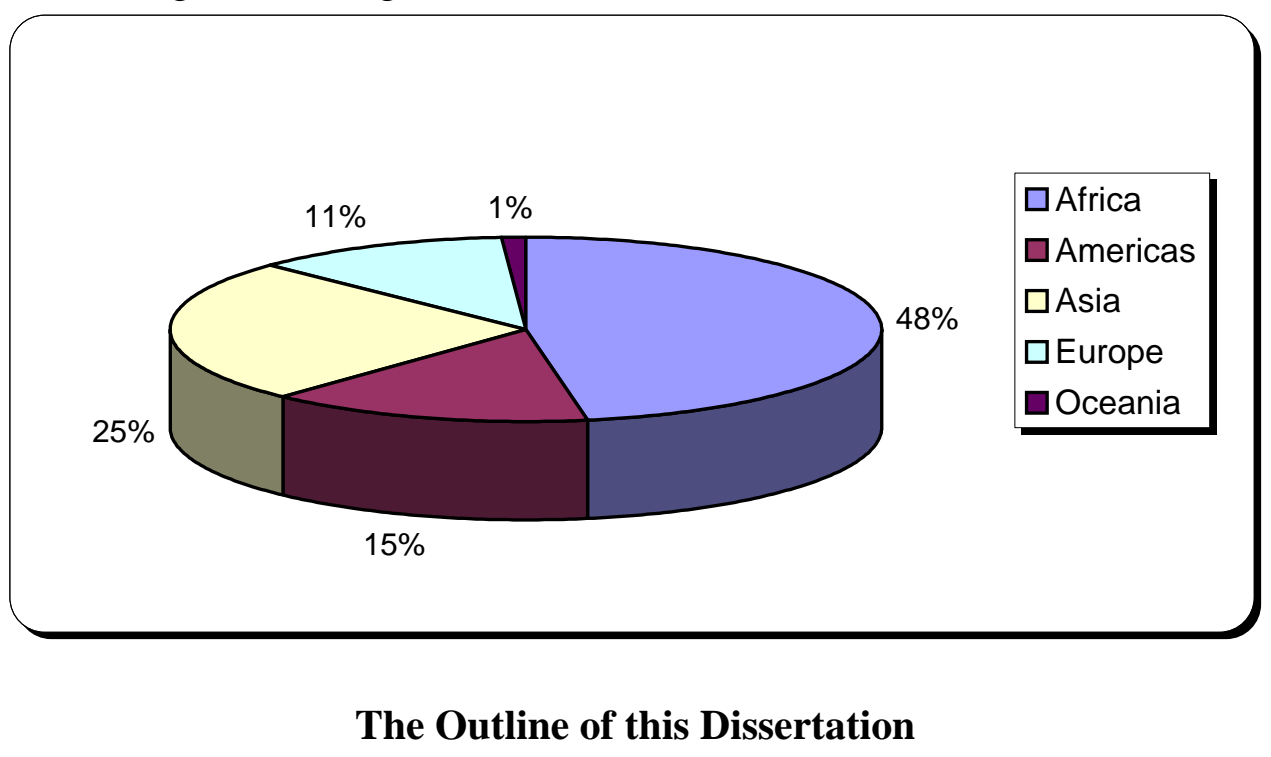

Chapter Two reviews the literature relevant to this dissertation. Although this dissertation is based within numerous different literatures, it is primarily concerned with the democratic peace and the democratization and war literatures. The chapter begins with a discussion of the various definitions of democracy and then explains the working definition of democracy for this dissertation research. This definition gives primacy to political institutions. Next, the chapter discusses the three different waves of democratization. The Third Wave, which began in 1974 (Huntington 1991), provides the theoretical justification regarding the time frame for this dissertation. The chapter continues with an explanation of the democratic peace and then addresses Mansfield and Snyder's negative assertion in the democratization and war literature. Next, the chapter examines the attributes of states that are more likely to cause involvement in armed conflict. Chapter Two continues with a discussion of political consolidation and political 
decay and then concludes with an explanation of the preconditions for democratization as discussed within the political development literature.

Chapter Three explains the theoretical argument of the dissertation. This chapter introduces the institutional threshold theory, which suggests that there are necessary and sufficient political conditions with regard to institutions that must be strengthened before democratic consolidation can occur. The chapter discusses the importance of political institutions to democratic consolidation. Next, the chapter delineates between governmental and intermediary institutions and provides an explanation of the thirteen component variables that make up the institutional index.

The research design of this dissertation is discussed in Chapter Four. The chapter begins by providing the research questions and hypotheses. Then the chapter explains the operationalization of the dependent, independent, and control variables that are necessary to this research, as well as an overview of the statistical methods and models used in the quantitative chapters.

Chapter Five is the first of three quantitative chapters that are necessary to test the research questions, hypotheses, and the institutional threshold theory. This chapter examines the relationship between political institutions and the level of democratization through the use of a time-series panel regression. Remaining consistent with previous literature, Chapter Six utilizes a time-series panel logit to test the statistical relationship between political institutions, the level of democratization, and a state's involvement in a militarized interstate dispute (MID). The final quantitative chapter, Chapter 7, expands upon previous research by using a time-series panel regression to test the association 
between political institutions, the level of democratization, and their combined effect on armed conflict.

Finally, Chapter Eight explains the conclusions of this dissertation research. Drawing conclusions across the three quantitative chapters, this final chapter answers the research questions and addresses the three hypotheses. In addition, areas of future research are outlined.

\section{Contributions}

This dissertation makes several contributions to the studies of international relations and comparative politics. First, the institutional threshold theory is an attempt to reconcile the optimism of the democratic peace with the pessimism of the democratization and war literature. In addition, the institutional threshold theory will attempt to identify the necessary and sufficient institutions which will enable democratic consolidation and by extension the passivity that exists among liberal democracies in the form of the democratic peace.

Second, the dissertation will introduce an institutional index which will allow for a comprehensive quantitative analysis to be performed on political institutions in anocracies. Until now, the literature has focused on qualitative examinations of political institutions or has only examined a limited number of political institutions. This dissertation examines thirteen different political institutions and combines them into an index to allow for quantitative analysis. Third, this dissertation will augment previous quantitative research by expanding the statistical techniques and applying the argument to internal as well as external armed conflict. 


\section{Chapter 2}

\section{Optimism versus Pessimism: The Democratic Peace versus Democratization and War}

\section{What is Democracy?}

The most basic definition of democracy, which can be traced to ancient Greece, is the rule of the people. Beyond this basic definition, there are many variations regarding the usage and employment of the term. Direct democracy, which is also referred to as classical or pure democracy, indicates a political system in which the citizens make the laws themselves rather than choosing representatives to make the laws on their behalf. However, direct democracy, scholars have argued, can only exist in small states. In the first experiment of democracy in Athens in ancient Greece until the $18^{\text {th }}$ century, direct democracy defined the meaning of the term.

Although contemporary theories of democracy tend to emphasize indirect democracy as a practical matter in large modern nation-states, the essence of modern direct democracy is still present in the form of participatory democracy. Participatory democracy seeks to involve the ordinary citizen more fully in the decision-making process. The goal is for the citizens to rule themselves. Participatory democracy involves extensive and active engagement of the citizens in the self-governing process; it means government not just for the people, but also by the people. In fact, participatory democracy grants citizens the authority to decide on policies and politicians are responsible for policy implementation. Participatory theorists, such as John Dewey and Benjamin Barber, believe that "the real benefits of democracy can only be appreciated and sustained by a society that is characterized by relatively high levels of citizen intervention in the tasks of governing” (Terchek and Conte 2001, p. 165). 
Most contemporary theories employ an indirect version of democracy because the modern nation-state is too large to practically use more direct forms of democracy. Representative democracy is delegating authority to chosen representatives who actually do the work of the government. These representatives remain accountable to the citizens through elections. Representative democracy demotes citizens to the role of watchdogs. Thus, democracy comes to mean legitimation of representative officials through periodic elections.

Protective democracy asserts "government is driven by its dual and sometimes competing commitments to liberty, on one hand, and its attentiveness to mass political interest groups on the other” (Terchek and Conte 2001, p. 91). In essence, the principal task of the government is to protect the liberty of its citizens. Advanced by theorists such as Friedrich Hayek (1979) and Milton Friedman (1962), protective democrats believe that the modern democratic state has become intrusive by accepting responsibilities that should remain with the citizens. In other words, the government should provide for minimum political arrangements that in turn will maximize freedom to its citizens.

Pluralist democracy suggests that interest groups form the foundation of democratic politics. Pluralist theory indicates that individuals maintain "distinct interests that need to be given the opportunity to be expressed politically” (Terchek and Conte 2001, p. 123). According to pluralists, a good democracy will allow like-minded individuals to gather and pursue their common interests. Pluralist theorists such as Arthur Bentley (1908) and Robert Dahl (1982) suggest that free people with like-minded interests logically collect together to defend and advocate for their interests, and in politics this means they form interest groups that request to be heard and affect policy. 
Performance democracy notes the shift away from the collective conception of politics to a more individualistic view, "namely that voters reference politics to their own well-being and leaders search not for a common good but a strategy that will get them elected or reelected” (Terchek and Conte 2001, p. 142).

Consociational democracy is a type of representative government in which power sharing is institutionalized. Consociational practices of democracy characteristically have existed in countries that are deeply divided by religious, ethnic, or linguistic cleavages. The intent of consociational democracy is to make certain that all the major segments in society are represented in the government in proportion to their size in the society. Thus, power sharing implies that the government is a coalition of the representatives of the segments.

The procedural theory of democracy, established by Joseph Schumpeter, rejects the two cardinal premises of classical democracy - the belief in the common good and the belief in the will of the people. In its place, Schumpeter offered his own explanation of democracy as a method for arriving at collective decisions through the process of a competitive struggle for people's votes. This definition reduces democracy to its basic essentials - electoral politics. Yet, procedural democracy is a method of reducing conflict through institutions that provide all citizens structured and limited participation in the discussion of issues and the choice of representatives. The goal is to arrive at negotiated solutions that all can accept.

Substantive democracy, on the other hand, is more concerned with cooperation and the idea that coercive institutions will eventually become unnecessary. Substantive democracy implies rule by, and policies, benefiting the masses of the poor. As opposed 
to procedural democracy, which is more focused on the institutionalized process of achieving an outcome, substantive democracy is concerned with those policies that benefit the masses of society, regardless of the decision-making process. According to Dahl, "carried to an extreme, the insistence that substantive results take precedence over processes becomes a flatly antidemocratic justification for guardianship and 'substantive democracy' becomes a deceptive label for what is in fact a dictatorship” (1989, p. 163).

According to a much employed contemporary definition of polyarchy, Dahl's term for the specific kind of democracy he describes, Dahl suggests that democracy has the following mechanisms: control of government decision-making lies with elected officials, elected officials are chosen through free and fair elections, inclusive suffrage, the right to run for office, citizens have a right to freedom of expression, alternative information sources exist, and citizens have the right to form independent associations (1989, 1971).

Although there are many definitions and types of democracy, this research employs a definition of liberal democracy proposed by Diamond (1999) because it is an institutionally richer definition of democracy. Diamond suggests that liberal democracies have the following components:

- Control of the state and its key decisions and allocations lies, in fact as well as constitutional theory, with elected officials (and not democratically unaccountable actors or foreign powers), in particular, the military is subordinate to the authority of elected civilian officials.

- Executive power is constrained, constitutionally and in fact, by the autonomous power of other government institutions (such as an independent judiciary, parliament, and other mechanisms of horizontal accountability).

- Not only are electoral outcomes uncertain, with a significant opposition vote and the presumption of party alterations in government, but no group that adheres to constitutional principles is denied the right to form a party 
and contest elections (even if electoral thresholds and other rules exclude small parties from winning representation in parliament).

- Cultural, ethnic, religious, and other minority groups (as well as historically disadvantaged majorities) are not prohibited (legally or in practice) from expressing their interests in the political process or from speaking their language or practicing their culture.

- Beyond parties and election, citizens have multiple, ongoing channels for expression and representation of their interests and values, including diverse, independent associations and movements, which they have the freedom to form and join.

- There are alternative sources of information (including independent media) to which citizens have (politically) unfettered access.

- Individuals also have substantial freedom of belief, opinion, discussion, speech, publication, assembly, demonstration, and petition.

- Citizens are politically equal under the law even though they are invariably unequal in their political resources.

- Individual and group liberties are effectively protected by and independent, nondiscriminatory judiciary, whose decisions are enforced and respected by other centers of power.

- The rule of law protects citizens from unjustified detention, exile, terror, torture, and undue interference in their personal lives not only by the state but also by organized nonstate or antistate forces (1999, pp. 11-12).

Because the recent pressure from the international community is based on the democratic peace, it is necessary to utilize an institutionally rich definition of democracy, since this type of state authenticates the democratic peace. Diamond present an institutional checklist that explains how liberal democracy is superior to more minimal definitions of democracy, such as those that are described with adjectives.

\section{Waves of Democratization}

According to Huntington, “a wave of democratization is a group of transitions from nondemocratic to democratic regimes that occur within a specified period of time and that significantly outnumber transitions in the opposite direction during that period of time” (1991, p. 15). To date, there have been three waves of democratization. Unfortunately, most waves are followed by reverse waves of democratization. 
The first “'long' wave of democratization began in the 1820's, with the widening of the suffrage to a large proportion of the male population in the United States, and continued for almost a century until 1926, bringing into being some 29 democracies” (Huntington 1996, p. 3). The first reverse wave initiated with Mussolini’s march on Rome in 1922, "and in 1942 there were only twelve democracies left in the world" (Huntington 1991-92, p. 579). According to Huntington,

the dominant political development of the 1920s and the 1930s was the shift away from democracy and either the return to traditional forms of authoritarian rule or the introduction of mass-based, more brutal and pervasive forms of totalitarianism. The reversals occurred largely in those countries that had adopted democratic forms just before or after World War I, where not only democracy was new but also, in many cases, the nation was new (1991, p. 17).

The second "short" wave of democratization began with the victory of the Allied states in World War II and culminated with "36 countries governed democratically, only to be followed by a second reverse wave (1960-75) that brought the number of democracies back down to 30” (Huntington 1996, p. 3).

The Third Wave of democratization began in Portugal in 1974 and since then "democratic regimes replaced authoritarian ones in approximately thirty countries in Europe, Asia, and Latin America” (Huntington 1991, p. 21). According to Huntington (1996, p. 4), several reasons contributed to the timing of the Third Wave such as the performance legitimacy of authoritarian regimes in comparison to democratic states, the unprecedented economic growth of the 1960s which expanded the middle class, and the transitions of earlier Third Wave states which served to stimulate and provide models for subsequent efforts at democratization. To date there is some evidence of a reverse Third Wave and indication that the Third Wave is over (Diamond 1996). The primary objective of the Third Wave states, and the international community, should be to prevent 
a massive third reverse wave. These actors should focus on consolidating the institutions that constitute liberal democracy and thus prevent democratic decay.

\section{Democratic Peace}

Democracy, a regime characteristic, has not typically been the driving force behind theories of international relations. Rather, international relations theories have been consumed with determining states actions and re-actions in an anarchic world. However, with the discovery of the relationship that exists between democracy and peace, this regime characteristic has lead to a dominant theory of international relations. The democratic peace also fuels the debate between realism and liberalism, since the democratic peace is seen as a liberal challenge to the dominant international relations theory of realism.

The democratic peace theory is a strong, empirically supported finding in the subfield of international relations. In fact, "the absence of war between democracies comes as close to anything we have to an empirical law in the study of international relations" (Levy 1989, p. 88). There are two main assumptions of the democratic peace.

Democracies rarely, if ever, go to war with other democracies. However, they are just as war prone as other types of regimes with non-democracies (Doyle 1986; Russett 1993; Russett 1993; Owen 1994). Most scholars do not debate the presence of the democratic peace; rather they differ over whether the normative or institutional explanation is more accurate.

The normative approach suggests that democracies do not engage in conflict because they externalize the norms of behavior that are developed domestically which characterize their political processes and institutions. Therefore, norms of compromise 
and cooperation prevent escalation. Shared values exist among democracies. They view each other as being democratic and therefore non-threatening. Democratic norms exist to settle conflict via compromise, bargaining, and founded upon the rule of law.

This dissertation will focus on testing the institutional explanation for the democratic peace. The institutional approach explains the restraint of the democratic peace as based on institutions, not the values of democracies. Democracies maintain a diffusion of power, usually through a system of checks and balances. Representative institutions can block war through the power of the purse. Leaders are constrained in democracies because the public must bear the cost of war (both economically and socially). International wars require political leaders to mobilize domestic support for their policies. Therefore, public opinion must be supportive of the policy. In addition, democracies generally have a slower decision-making process, whereas authoritarian regimes are less responsive to public opinion and face fewer institutional constraints in their decision-making process.

Despite the strong empirical findings of the democratic peace, not all scholars are convinced that it is possible to generalize from the experience of the Western democracies. Realist scholars in particular remain skeptical. Spiro (1994) suggests that the democratic peace is a statistical artifact, indicating the statistical insignificance of the absence of democratic wars. He suggests that this is simply a Cold War phenomenon and that as the number of democracies grow, the democratic peace will cease to exist. Faber and Gowa (1995) expand upon this style of research by dividing international conflict into multiple time periods. They determine that the democratic peace is only significant for the Cold War era. Both Spiro and Faber and Gowa attribute the peace during the 
Cold War to the fact that democratic states were forced to ally against a common aggressor. Thompson (1996) suggests that democratic peace theorists have the causal direction in reverse (or "putting the cart before the horse") suggesting that it is not democracy that brings about peace. Rather, it is peace that allows for democracies to form. Oren (1995) challenges the democratic peace based upon the variation in the definitions of democracy. He suggests that the peace is simply a creation of limited definitions in order to explain deviant cases. Finally, Herrman and Kegley (1995) attribute the democratic peace phenomenon to political psychology. They suggest that cognitive factors are the true explanations. Democratic leaders identify with other democratic leaders as being similar to themselves. In turn, they project assumptions about morality and behavior onto their adversaries. Democratic states view each other as similar and will not engage in conflict because they are part of the "in-group."

Because of the attractions of the democratic peace, its influence has spread beyond academicians to politicians and policy-makers. Politicians believe that war is not yet obsolete, but it is on its way to becoming so with the growing number of democratic states. More specifically, the optimism of the international community is based on the following logic: "the number of democracies in the world has increased rapidly in recent years and democracies do not fight one another; therefore, we can look forward to a much more peaceful world with international relations characterized by cooperation instead of conflict” (Sorensen 1998, p. 95). However, what the international community has failed to realize is that the majority of states that have recently taken steps to democratize do not meet the strict definition of liberal democracies and therefore may not validate the 
democratic peace. In fact, these newly democratizing states may be more war prone, both internally and externally, than any other type of regime.

\section{Democratization and Conflict}

It can be argued that Snyder and Mansfield have provided a third contradictory assumption to the democratic peace. It is such a compelling finding that it should cause the international community to reevaluate their policies concerning democratization. The international community should be very precise in promoting mature, liberal, consolidated democracy and wary of other forms of democracy, such as pseudodemocracy, authoritarian democracy, electoral democracy, etc., that may deliver the least desired outcomes.

Snyder and Mansfield have conducted research which indicates that states making the transition to democracy, known as anocracies, are more war prone, both internally and externally, than either democratic or authoritarian regimes. Specifically, "democratizing states were, on average, about 60 percent more likely to go to war than states that were not democratizing” (Mansfield and Snyder 1995, p. 13). In addition, they will engage in conflict with either democracies or non-democracies (1995; 1995; 2002; Snyder 2000). Mansfield and Snyder indicate that democratizing states will emphasize diversionary tactics by accentuating foreign threats and highlighting nationalism. However, these rocky transitions surrounding democratizing states can be avoided, according to Snyder, if "leaders are willing to adopt a strategy of institution-building before embarking on democratization. The gradual development of the rule of law, an impartial bureaucracy, civil rights, professional media, followed by free elections,” 
should be able to create a transitional democracy which does not succumb to nationalist fervor and conflict (2000, p. 41).

Critics of the democratization and war literature have reevaluated the research conducted by Mansfield and Snyder. These critics have concluded that the process of democratization is not as inherently dangerous as previously suggested by Mansfield and Snyder. Enterline performs what he calls a more "straightforward research design" to determine that "democratizing states are not more likely, on average, to participate in interstate war than are states not undergoing a political transformation” (1996, p. 191). He indicates that war involvement does not increase with the process of democratization; rather it is more closely affiliated with autocratizing states. Gleditsch and Ward agree with Enterline’s assessment that the "risks of war are reduced by democratization and exacerbated by reversals in the democratization process” (1997, p. 51). Mansfield and Snyder (2002) have responded to these criticisms with further empirical evidence supporting the democratization and war connection. However, they have produced an exception to the argument which suggests that democratic transitions that occur rapidly are less likely to produce war involvement.

Because evidence of the democratic peace exists, international pressure forces states to begin the process of democratization. However, as Snyder and Mansfield have demonstrated, this transition period is concerning. Anocracies, which it can be argued are pseudodemocracies, are unstable and violent, and states often become entrenched in this category. Anocracies undermine the democratic peace and its principles of international peace, security, and cooperation. Therefore, an effort must be made to 
understand what institutions can expedite the process of democratic consolidation and prevent states from becoming entrenched anocracies.

\section{Conflict}

A possible consequence of the democratization process is the heightened chance that democratizing states will become more war prone, both internally and externally. This relatively recent discovery by Mansfield and Snyder adds to an area of international relations literature that has long been trying to identify the characteristics that cause conflict. Most research in this area is conducted using the interstate dyad as the unit of analysis. Although the interstate dyad is not the proper unit of analysis for this dissertation, the predictors of conflict identified within the literature are relevant.

A well-established predictor of conflict between states is the presence of a contiguous relationship. States that share a common border, whether by land or by sea, are more likely to experience a conflict of interest that can lead directly to interstate friction, increase tensions, and enhance the likelihood for war. Contradictory information is present within the conflict literature indicating that alliances can either mitigate or enhance the likelihood of interstate conflict. Conventional wisdom asserts that "allies are more likely to resolve disputes by means other than war and, therefore, are less likely to engage in war with one another” (Bremer 1992, p. 315). However, in more sophisticated empirical analysis, Bremer discovers the "paradoxical proposition that alliances encourage war between members rather than inhibiting it” (1992, p. 328). This finding is based upon the logic that states engage in alliances to combat a temporary problem and are not long-standing, static agreements. 
The presence of power parity is also widely debated in the conflict literature. There is evidence to suggest that possessing the preponderance of power will promote peace because no state will initiate a conflict against a stronger, more powerful state if it cannot win. Alternatively, it is argued that equality in power encourages peace between states. Since neither side can be certain of victory, the war will not be initiated. Bremer finds that possessing a preponderance of the power is a deterrent to conflict in an interstates dyad. It has also been discovered that major powers are more war prone than minor powers. Major powers engage in more active foreign policy because they are interested in keeping their major power status.

Once again there is a contradiction within the conflict literature regarding the role of economic development and war. The first argument indicates that more economically advanced states will conflict with one another as they attempt to gain "markets and resources in a largely zero-sum world" (Bremer 1992, p. 317). The second argument suggests that conflict is more likely to occur between the "haves" and the "have nots" since the "have nots" are being exploited for markets and resources. Bremer discovers that conflicts are more likely to occur between economically disadvantaged groups, or between the "haves" and the "have-nots," rather than between economically advanced states.

Finally, the conflict literature has identified militarization as a predictor of war. Two scenarios are possible. Based upon the logic of deterrence, states that dedicate resources to militarization are less likely to be involved in war. However, increase militarization can be mistaken as aggressive and may therefore result in war. Bremer find little evidence to support either scenario. Overall, the conflict literature is valuable 
to this dissertation research since it has identified predictors or characteristics that may lead to war.

\section{Political Consolidation and Political Decay}

If the first important task for states is to establish democracy, the second, and no less important, task is to sustain democracy. This is the process known as political consolidation. Although the term political consolidation is somewhat ambiguous, the minimal definition is "meant to describe the challenge of making new democracies secure, of extending their life expectancy beyond the short term, of making them immune against the threat of authoritarian regression, and building dams against eventual 'reverse waves”” (Schedler 1998, p. 90). Therefore, “consolidation is the process of achieving broad and deep legitimation, such that all significant political actors, at both the elite and mass levels, believe that the democratic regime is better for their society than any other realistic alternative they can imagine” (Diamond 1996, p. 33). Or, to explain democratic consolidation in the simple term of Linz, democracy must be widely accepted and seen as the “only game in town” (1990, p. 156).

According to Diamond, there are three tasks necessary to consolidate democracy: “democratic deepening, political institutionalization, and regime performance” (1999, p. 74). The process of deepening "makes the formal structures of democracy more liberal, accountable, representative, and accessible - in essence, more democratic” (Diamond 1999, p. 74). Political institutionalization is a move toward routinized, recurrent, and predictable patterns of political behavior” (Diamond 1999, p. 74). It is the process of “strengthening the formal representative and governmental structures of democracy so that they become more coherent, complex, autonomous, and adaptable and thus more 
capable, effective, valued, and binding” (Diamond 1999, p. 75). The final task of political consolidation is regime performance. "Over time and over a succession of specific governments, the democratic regime must produce sufficiently positive policy outputs to build broad political legitimacy or at least to avoid the crystallization of substantial pockets of resistance to the regime’s legitimacy” (Diamond 1999, p. 74).

If the process of political consolidation does not occur, it is likely to be replaced by democratic breakdown or decay. Democratic breakdown is essentially the sudden death of democracy. It is the "dramatic, sudden, and visible relapses to authoritarian rule” (Schedler 1998, p. 97). This democratic breakdown can be caused by a variety of reasons, such as the loss of the legitimacy of a democratic regime, a military coup, revolution, or a disloyal opposition that intends to question or change the regime (Linz 1978).

The process of political decay is less dramatic than democratic breakdown, but it is no less significant. "Many new democracies have to contend with the danger of decay, of less spectacular, more incremental, and less transparent forms of regression” (Schedler 1998, p. 97). According to Schedler, democratic breakdown "provokes a radical discontinuity with democratic politics (leading to open authoritarianism)," while democratic decay "implies a gradual corrosion leading to fuzzy semidemocracy, to a hybrid regime somewhere between liberal democracy and dictatorship” (1998, p. 97).

\section{Political Development}

Scholars have identified several preconditions of democratization that are essential to the formation and consolidation of liberal democracies. These preconditions include: a relatively high level of economic development, a relatively low level of 
socioeconomic inequality, and a majority of the population that is literate. Other scholars also point to having a history as a British colony and having a majority Protestant population.

The first precondition is a relatively high level of economic development. In 1959 Lipset "highlighted the seeming correlation between high levels of economic development and the prevalence of democratic political systems” (Huntington 1984, p. 198; Przeworski 1996; Curtis 1997; Przeworski 2000; Diamond 1996; Seligson 1987). Lipset goes on to suggest that the "more well-to-do a nation, the greater the chance that it will sustain democracy" (Huntington 1984, p. 198). The "evidence is overwhelming that economic development has a strong positive effect on democratization” (Huntington 1997, p. 4). In addition, Seligson (1987) has indicated that an economic threshold effect exists before states can make the successful transition to democracy. Huntington (1997, p. 4) suggests several reasons that explain the correlation between high economic development and the level of democratization. Economic development involves higher levels of urbanization, literacy, and education while producing more resources for distribution among groups in society. Economic growth produces a more complex economy that becomes increasingly difficult for the state to control. In addition, the easing of state control of the economy leads to the creation and growth of independent centers of power. Finally, Huntington acknowledges that in the short term rapid economic growth often exacerbates income inequalities, in the longer term it produces greater equality in income distribution.

In close association to a relatively high level of economic development is the related concept of socioeconomic inequality levels. Although it has been established that 
during the initial stages of rapid economic growth inequalities can be exacerbated, this effect becomes more egalitarian over time. Simon Kuznets (1955) describes in his inverted-U-shaped curve that when an economy is largely agricultural and underdeveloped it has a low level of income inequality, then during industrialization income inequality increases, and finally at some crucial point income inequality starts to decrease over time. Muller (1988) suggests that democracy must be present for at least twenty years before an egalitarian effect starts to occur. This egalitarian effect is necessary because, according to Diamond, Linz, and Lipset, “deep, cumulative social inequalities represent a poor foundation for democracy” (1995, p. 24).

Seligson (1987) suggests that a threshold effect exists regarding the literacy level of a democratizing state. Particularly, fifty-one percent of the population must be literate. Essentially, education is a basic requirement for the establishment of democracy. Rowen indicates that "there are two ways in which education can influence democracy: one is directly, through the effect that an educated citizenry can have on political processes and institutions. The other is indirectly, through education's contribution to higher incomes” (1996, p. 311).

Within the area of cultural theory, two aspects are necessary for democratization. The first is the idea of political learning which is associated with British colonial rule. This colonial legacy suggests, according to Myron Weiner,

every single country in the Third World that emerged from colonial rule since the Second World War with a population of at least one million (and almost all the smaller colonies as well) with a continuous democratic experience is a former British colony. British rule meant not democracy - colonialism is by definition undemocratic - but constitutional liberalism. Britain's legacy of law and administration has proved more beneficial... (Zakaria 1997, p. 29). 
In addition, Przeworski suggests that "democracies are somewhat more likely to survive in countries that were British colonies” (2000, p. 126). Therefore, states that have a history as a British colony should produce a positive effect on the level of democratization.

The second related precondition to cultural theory is the idea that the majority of the population should be Protestant. Weber's idea of the Protestant ethic states that areas that were colonized by Protestant countries had a more likely chance of developing. Beliefs and disciplines associated with Protestantism gave these states an advantage over Catholics, or other religions, trying to develop. Lipset suggests "the emphasis within Protestantism on individual responsibility furthered the emergence of democratic values" (Prezworski 2000, p. 126). Weber also identified the correlation between Protestantism, individualism, and capitalism. States that embrace individualistic and capitalistic attitudes are more likely to develop democracy. According to these theorists, Catholicism, Islam, and Confucianism lack the individual discipline necessary to promote democratization. Therefore, there should be a positive correlation between Protestantism and the level of democratization. 


\section{Chapter 3 - The Institutional Threshold Theory \\ Political Institutions}

According to Mansfield and Snyder, "the happy outcomes of the democratic peace emerge only after a transition to democracy is well consolidated” (2002, p. 300). Mature liberal democracies are dependent upon the successful strengthening of institutions. Political institutions are public bodies "with formally designated structures and functions, intended to regulate certain defined activities which apply to the whole population” (Bealey 1999, p. 166). They are a system through which power is distributed, exercised, and regulated in society. As Soskice explains, institutions "perform a major function for society (which is) to induce stability and consistency in collective life” (1992, p. 548). Thus, institutions “create definite, continuous, and organized patterns of behavior by individuals, imparting predictability and regularity to the basic activities of human society” (Soskice 1992, p. 548).

According to Diamond, Linz, and Lipset there are several reasons as to why political institutionalizations are "strongly related to the persistence and stability of democracy” (1995, p. 33). The first reasons explains that "institutions structure behavior into stable, predictable, and recurrent patterns," therefore “institutional systems are less volatile and more enduring, and so are institutionalized democracies” (1995, p. 33). Secondly, Diamond, Linz, and Lipset explain, “democracies that have more coherent and effective political institutions will be more likely to perform well politically in maintaining not only political order but also a rule of law, thus ensuring civil liberties, checking the abuse of power, and providing meaningful representation, competition, choice, and accountability” (1995, p. 33). The third reason for the importance of 
institutions explains, "well-institutionalized democracies are also more likely to produce workable, sustainable, and effective economic and social policies because they have more effective and stable structures for representing interests and they are more likely to produce working congressional majorities or coalitions that can adopt and sustain policies” (Diamond, Linz, and Lipset 1995, p. 33). Finally, “democracies that have capable, coherent democratic institutions are better able to limit military involvement in politics and assert civilian control over the military” (Diamond, Linz, and Lipset 1995, p. 33).

Therefore, it has been established that political institutions act "as a key factor affecting the viability and stability of democracy" (Diamond, et. al. 1997, p. xxii). The international community will continue to advocate democratization, however policies to foster democratic transitions should be accompanied by efforts to mold strong, centralized institutions that can withstand the intense demands on the state and political elites posed by high-energy mass publics.

According to Diamond, Linz, and Lipset “political leadership has been a notable and oft-neglected factor in the pursuit of democratic consolidation” (1995, p. 17). "Democratically loyal leaders reject the use and rhetoric of violence and illegal or unconstitutional means for the pursuit of power, and they refuse to condone or tolerate antidemocratic actions by other participants” (Diamond, Linz, and Lipset 1995, p. 16). Although political leadership often influences the fate of democratic transitions, it is not the only important factor concerning the executive. Equally important are executives that are constitutionally constrained and accountable to horizontal actors (Diamond 1999). 
Often in new and unconsolidated democracies, legislative and judicial branches are weak or non-existent in relation to an exalted executive. However, "elected legislatures (at all levels of governance) are a crucial institution for the representation of interests and horizontal accountability" (Diamond 1999, p. 98). According to Diamond, "if legislatures are to become meaningful forums for injecting the interests and concerns of their constituencies into the policy process, they must have sufficiently elaborated and resourceful organizational structures so they can engage, challenge, and check executive officials and state bureaucracies” (1999, p. 98). In order for legislatures to serve their intended role as a check on the executive branch and an advocate for their constituents, they must have the "organization, financial resources, equipment, experienced members, and staff to serve as a mature and autonomous” actor (Diamond 1999, p. 98). Not only is the legislative branch often a weak actor in democratizing states, the judicial systems "are feeble and ineffective, crippled by endemic corruption, intimidation, politicization, and lack of resources in training” (Diamond, Linz, and Lipset 1995, p. 41). However, it is important to stress the significance of a strong and independent judiciary in the democratizing process. In order to provide for the rule of law, enforce a democratic constitution, protect individual and collective rights, constrain and hold accountable the elected officials, "the judicial system must have a high degree of institutional coherence, capacity, and autonomy” (Diamond 1999, p. 75).

In order for a state to consolidate democracy, "a usable bureaucracy” is necessary (Linz and Stepan 1997, p. 20). A usable bureaucracy acts as the "administrative capacity to perform the essential functions of government: to maintain order, adjudicate disputes, construct infrastructure, facilitate economic exchange, defend the national borders, and 
collect the necessary taxes to fund these activities” (Diamond, et.al. 1997, p. xxiii). The bureaucracy also serves as deterrence to political corruption. States that employ a professionalized meritocratic bureaucracy, instead of a civil service based on patronage, are more likely to consolidate democracy (Diamond 1999; Diamond, et.al. 1997; Diamond, Linz, and Lipset 1995).

The first step a new democracy must take is establishing a de-jure or de-facto constitution that provides the guidelines for democratic governance. Constitutionalism is “a complicated system of checks and balances designed to prevent the accumulation of power and the abuse of office. This is done not by simply writing up a list of rights but by constructing a system on which government will not violate these rights” (Zakaria 1997, p. 41). Constitutions are "also meant to tame the passions of the public, creating not simply democratic but deliberative government” (Zakaria, p. 1997 41).

A related aspect to the constitutional structure is the decision concerning the electoral system choice of parliamentarism versus presidentialism. Several reasons are provided by Diamond, et. al. (1999), Linz (1990); and Prezworski (1996) to explain why parliamentary democracy is more viable than presidentialism. First, “a presidential system tends to concentrate power in the executive branch and to facilitate claims to plebiscitarian legitimacy” (Diamond, Linz, and Lipset 1995, p. 39). “Second, presidentialism can give rise to a paralyzing deadlock between the executive and the legislature” (Diamond, Linz, and Lipset 1995, p. 39). “The third problem with presidentialism is tied to and exacerbated by its majoritarian nature, which tends to make politics a zero-sum game in which power sharing is difficult and legislative coalitions are much more difficult to form and maintain” (Diamond, Linz, and Lipset 1995, pp. 39-40). 
Finally, "presidentialism, with its fixed terms, rigidifies outcomes, possibly sticking a nation - even for several years - with a government that has utterly lost public confidence and support” (Diamond, Linz, and Lipset 1995, p. 40).

Another concern for new democracies in the consolidation process is the establishment of political parties. According to Diamond, political parties are "an indispensable institutional framework for representation and governance in a democracy" (1999, p. 96). Mainwaring suggests, "in an institutionalized party system, there is stability in who the main parties are and in how they behave” (1998, p. 68). Mainwaring also provides four dimensions of party institutionalization: more institutionalized party systems enjoy considerable stability; more institutionalized systems are ones in which parties have strong roots in society; in more institutionalized systems, the major political actors accord legitimacy to parties; and finally, in more institutionalized systems, party organization matters (1998, pp. 68-69). Without effective political parties that provide a voice for citizens and opposition, and can govern effectively, the successful democratic consolidation becomes less certain.

In addition to legitimizing the above institutions, “democracy cannot be consolidated until the military becomes firmly subordinated to civilian control and solidly committed to the democratic constitutional order” (Diamond, et. al.1997, p. xxvii; Dahl, 1989). "When the military as an institution has a long tradition of political intervention and retains extensive political and economic prerogatives, new democracies face a particularly difficult and dangerous challenge" (Diamond 1999, p. 113). Therefore, "the challenge for democratic consolidation, then, is to gradually roll back these prerogatives 
and refocus the military's mission, training, and expenditures around issues of external security” (Diamond 1999, p. 113).

Press freedom is also a necessary element to democratic consolidation. Van Belle has demonstrated that a "high degree of correlation" exists "between press freedom and democracy” (2000, p. 51). Press freedom is necessary to provide for an arena of political competition. In authoritarian states and pseudodemocracies, the press is restricted and controlled by the government and it is therefore unable to serve as an arena of political competition or debate.

The final institutional area that must be renovated for democratic consolidation concerns the free and fair elections of political officials. As Huntington suggests "selecting rulers through elections is the heart of democracy" (1991, p. 267). However, as this research has tried to demonstrate, it is not enough to declare success with electoral democracies, rather this is a minimalist definition of democracy. With that said, the process of selecting leaders through free and fair elections is fundamental to democratization.

"Freedom entails the right and the opportunity to choose one thing over another" and "fairness means impartiality" (Elklit and Svensson 1997, p. 35). "If a country holds competitive, multiparty elections, we call it democratic. When public participation is increased, for example through the enfranchisement of women, it is seen as more democratic” (Zakaria 1997, p. 25). Therefore, competitive elections are necessary for democratization and universal suffrage is necessary for deepening democracy. 
In "Why Elections Matter," Elizabeth Spiro Clark presents a summary of the Organization of Security and Cooperation in Europe's (OSCE) minimum electoral standards. Suggested by these minimum standards are five criteria:

- elections will be held under universal and equal suffrage at reasonable intervals, as established by law, for, at a minimum, all seats in one chamber of the legislature;

- the executive must be accountable either directly to the electorate or to elected legislators;

- there must be a clear separation between parties and state;

- individuals have the right to stand for office, organize themselves in political parties, obtain information, and access to the media unimpeded by intimidation to administrative obstacles on a basis of equal treatment before the law and by the authorities, and to serve out their terms of office; and

- votes are to be cast by secret ballot, or equivalent, and honestly counted, reported and made public (Clark 2000, p. 30).

\section{Governmental versus Intermediary Institutions}

Political institutions are imperative to democratic societies because they structure behavior in predictable and regular fashions. As a result, they provide for democratic consolidation and long-term stability by making the "government authorities accountable to the average voter” (Mansfield and Snyder 2005, p. 51). This dissertation distinguishes the broad category of political institutions into two smaller categories called governmental and intermediary institutions.

Governmental institutions are the formal institutions that create the government itself. They hold the real decision-making powers of the government. Examples of governmental institutions are the executive, legislative, and judicial branches, the constitution, which explains the divisions of these formal powers, and the military, which acts on behalf of the governmental institutions. 
Alternatively, intermediary institutions serve "to link citizens to their government” (Pharr 2000, p. 14), "aggregate and channel social demands within the political arena” (Roberts 1996, p. 113), and "represent citizens to and in the state" (Jensen and Phillips 1996, p. 118). In other words, intermediary institutions serve as the liaison or conduit between the citizens and the state. These are the mechanisms that allow the government to reach the citizens and allow the citizens to reach the government. Examples of intermediary institutions are political parties, the press, elections, and the bureaucracy.

\section{The Institutional Threshold Theory}

The recent pressure to democratize that has been levied upon states from the international community has its origins in the peace, security, and cooperative implications of the democratic peace. The democratic peace views the proliferation of democracy as a constructive force in world politics, yet the democratization process only serves to aggravate the hostilities intrinsic in international relations. The institutional threshold theory is an attempt to reconcile the optimism of the democratic peace with the pessimistic standpoint of the democratization and war literature by discovering the political institutions that serve as the "lynch pins" of democratic consolidation and by extension the prevention of armed conflict. By reducing the amount of time states spend in the democratizing process, the inherently dangerous and disruptive behavior that accompanies democratization can be mitigated, therefore leading to a reduction in the conflict levels of democratizing states.

The institutional threshold theory suggests that there are necessary and sufficient institutions that must be strengthened before democratic consolidation can occur. States 
must pass through this institutional threshold, which means that the majority of the following institutions must be strengthened: the role of the executive must be constitutionally constrained and political executives must maintain favorable attitudes towards democracy; the legislative branch must act as a check on executive officials and have the ability to advocate for their constituents; the judicial system must act as an independent actor that can guarantee the rule of law; a meritorious bureaucracy must be established; a constitution must be in place that prevents the accumulation of power and abuses of office through a system of checks and balances; opposition political parties must be allowed to form; the military must hold a subordinate role to elected officials; freedom of the press is necessary to provide for an open debate arena; and elected officials must be selected through free and fair elections.

The institutional threshold theory does not act as a prerequisite for democracy “with adjectives” because in most democratizing states a pseudodemocracy, authoritarian democracy, electoral democracy, etc. has already been established. The theory does, however, act as the primary function necessary for democratic consolidation to occur and a mature democracy to develop.

There are two alternative scenarios or paths that countries can travel according to the institutional threshold theory. As Figure 3-1 shows, the first scenario suggests that countries become anocracies, which indicates a hybrid regime consisting of both authoritarian and democratic traits. States then progress towards democratization, indicating that they have become new or transitional democracies, yet they do not possess viable political institutions that authenticate the democratic peace. Those states that actually pass through the institutional threshold, meaning they have strengthened a 
majority of their institutions, will then consolidate democracy and validate the democratic peace and the passivity that exists between liberal institutionalized democracies. In this scenario, the inherent dangers of the democratizing process have been mitigated because political institutions have been strengthened and therefore provide mechanisms that channel and regulate behaviors of the elites and masses alike. Political elites no longer must resort to the promotion of diversionary tactics, emphasize foreign threats, or endorse nationalist rhetoric. Rather, the regime reforms provided by the institutions allow for the accommodation of political opposition groups and social cleavages that exist in all societies.

The alternative scenario applies to those states that do not pass through the institutional threshold. These states have not strengthened a majority of the necessary and sufficient political institutions, are therefore unable to consolidate democracy, and are at risk for becoming an entrenched anocracy. This lack of democratic consolidation suggests that states are still at risk for heightened conflict that exists for democratizing states. Instead of focusing on regime reforms and strengthening their political institutions, these states are still susceptible to diversionary tactics and nationalist fervor that leads to both internal and external conflict because there are not political institutions in place to regulate behavior. 


\section{Figure 3-1. The Institutional Threshold Theory}

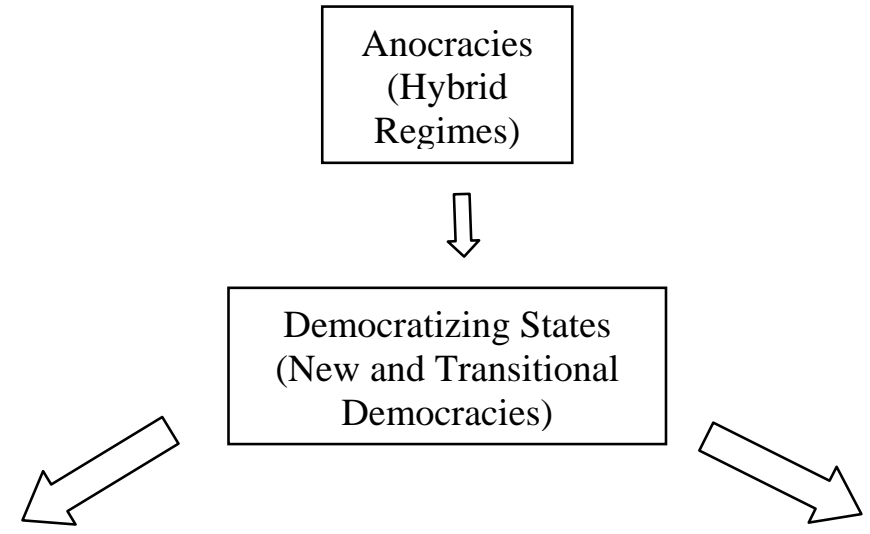

\begin{tabular}{c}
$\begin{array}{c}\text { Strengthening of } \\
\text { Governmental } \\
\text { Institutions }\end{array} \Longleftrightarrow \Delta \begin{array}{c}\text { Strengthening of } \\
\text { Intermediary } \\
\text { Institutions }\end{array}$ \\
\hline
\end{tabular}
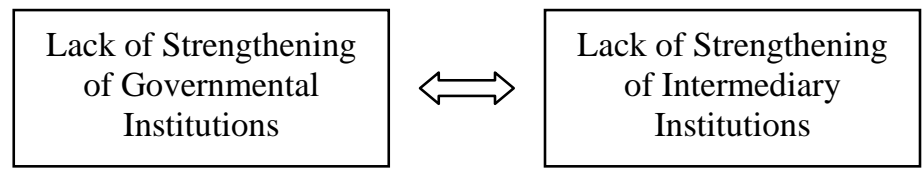

or

Lack of Strengthening of Governmental Institutions

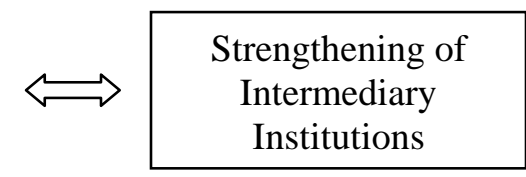

or
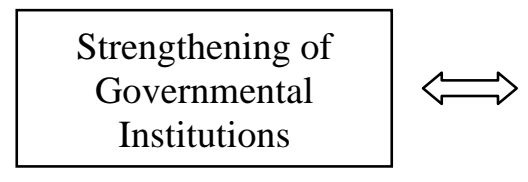

Lack of Strengthening of Intermediary Institutions

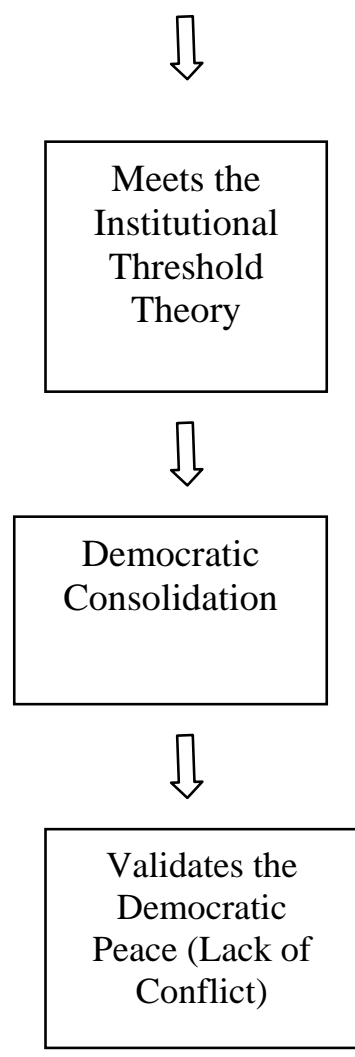

Does Not

Meet the

Institutional

Threshold

Theory<smiles>[CH]=C</smiles>

Lack of Democratic Consolidation

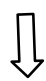

Does Not Validate the Democratic Peace (Still at Risk for Conflict) 


\section{Chapter 4 - Research Design \\ Introduction}

The fundamental objectives of this dissertation are to quantitatively test the institutional threshold theory outlined in Chapter Three and to identify the political institutions that create mature democracies, which are not subject to armed conflict, and in turn validate the democratic peace. In order to assess the institutional threshold theory, answer the research questions, and test the related hypotheses, three quantitative chapters are necessary. Chapter Five examines the relationship between political institutions and the level of democratization. Chapter Six and Seven examine the relationship between political institutions and armed conflict. Chapter Six focuses on the Militarized Interstate Dispute data set as the measure of conflict, which remains consistent with previous research. Chapter Seven employs the Armed Conflict data set, which expands upon the limitations of previous research.

Considering that the states of interest in this dissertation research are anocracies, which are at worst underdeveloped and at best developing, many of the variables are limited. Several variables do not cover the entire time span of interest (1974 through 2000) and some variables do not cover all states of interest. As a result of the variable limitations, four data sets, which employ different time frames, states, and variables, are included. Descriptions of the four datasets are as follows ${ }^{4}$ :

- 1974 through 2000 - This dataset covers the entire time span of interest, however, it includes a subset of countries. Seventy states are analyzed in this dataset.

- Entered System Late - This data set includes all states of interest in the research which is a total of eighty-seven. It incorporates states that entered the system

\footnotetext{
${ }^{4} \mathrm{~A}$ list of the countries of interest for each data set can be found in the Appendix 2.
} 
after 1974, such as Namibia, Mozambique, and those states that gained independence as a result of the Soviet Union collapse. It covers the years 1991 through 2000.

- Rule of Law / Bureaucratic Quality - The data set incorporates the rule of law and bureaucratic quality component variables in the institutional index. However, this data could only be collected for sixty-two states covering the years 1982 through 1997.

- Regime Change - The final data set includes a regime change control variable. Once again, the data does not exist for all states of interest. Sixty-two states are analyzed covering the years 1974 through 1992.

Although it is less than ideal to use four different data sets, since it makes comparisons across years and states more difficult, it is necessary because of the limitations of the variables. The use of the four data sets allows for all possible scenarios to be analyzed including the maximum number of years, countries of interest, and various dependent, independent, and control variables.

\section{Questions and Hypotheses}

In an effort to understand the reasons why some states are able to consolidate democracy and then enjoy the pacificity that exists among democratic states, several research questions and hypothesis have been developed. Is democracy promotion a valuable policy tool to ensure world peace, or are the policy-makers inadvertently advancing conflict as suggested by Mansfield and Snyder? Which political institutions are necessary to ensure democratic consolidation and by extension prevent armed conflict through the validation of the democratic peace? Is there a difference between 
governmental institutions and intermediary institutions in democratic consolidation and the prevention of armed conflict? Similar to the threshold that exists for the gross national product and literacy rates, is there an institutional threshold necessary for states to democratize? In order to answer these questions, the following hypotheses were generated:

H1. States that are making the transition to democracy while establishing strong political institutions, as evidenced by a higher institutional index score, are more likely to consolidate democracy.

H2. States that are making the transition to democracy while establishing strong political institutions, as evidenced by a higher institutional index score, are less likely to be involved in armed conflict.

To appropriately test the institutional threshold theory, two stages of analysis are necessary. The first stage of analysis examines the relationship between political institutions and the level of democratization. The second stage analyzes the relationship between political institutions, the level of democratization, and their combined impact on conflict. Hypothesis 1 is tested in Chapter 5 and Hypothesis 2 is tested in Chapters 6 and 7. A two-stage analysis is necessary because political institutions are critical to democratic consolidation. Institutions must be strengthened before democratic consolidation can occur. Only when states consolidate democracy do they meet the conditions of the democratic peace and the passivity that exists between its members.

H3. Governmental institutions have a greater positive influence on democratic consolidation than intermediary institutions.

This dissertation differentiates between governmental and intermediary institutions. Governmental institutions are the organizations that hold the formal powers of the government. Intermediary institutions are those that link the citizens to the government. In other words, intermediary institutions are the conduit between the people 
and the governmental institutions. Although both governmental and intermediary institutions are necessary to democratic consolidation, this hypothesis suggests that governmental institutions must first be strengthened before intermediary institutions can serve their function as a linking mechanism between the government and the citizens. The variable categorization is listed in Figure 4-1.

Figure 4-1. Classification of Governmental and Intermediary Institutions

\begin{tabular}{|c|c|}
\hline GOVERNMENTAL INSTITUTIONS & INTERMEDIARY INSTITUTIONS \\
\hline Openness of Executive Recruitment & Party Legitimacy \\
\hline Constraints on the Chief Executive & Bureaucratic Quality \\
\hline Legislative Effectiveness & Press Freedom \\
\hline Legislative Selection & Free and Fair Elections \\
\hline Constitutional Checks & Universal Suffrage \\
\hline Rule of Law & \\
\hline Military & \\
\hline Electoral System & \\
\hline
\end{tabular}

Of the thirteen component variables that are included in the institutional index, five are considered intermediary institutions. They are regarded as such because they serve as a liaison between the citizens and the government. The remaining eight institutions are considered to be governmental institutions since they hold more formal powers. Each component variable of the institutional index is tested for its impact on the level of democratization and conflict.

\section{Methodology}

In order to assess the significance of the institutional threshold theory and the related hypotheses, two research methodologies are employed in three quantitative chapters. Through the use of a time-series panel regression, Chapter 5 examines the relationship between political institutions and the level of democratization. Chapter 6 quantitatively examines the relationship between Militarized Interstate Disputes, political 
institutions, and the level of democratization. A time series panel logit is used to examine the relationship. Finally, Chapter 7 assesses the impact of the Armed Conflict data set, political institutions, and the level of democratization through the use of a time series panel regression.

\section{Explanation of Chapter 5}

Chapter 5 is the first stage of the two-stage analysis necessary to test the relationship between political institutions, the level of democratization, and conflict. This chapter tests the impact that political institutions have on the level of democratization. It does so for the four different data sets. A time series panel regression, also called a cross-sectional time series regression, is used to analyze the theory and related hypotheses. This type of analysis deals with two-dimensional panel data. The data is collected over time and states and then a regression model is performed on these two dimensions. Time series panel regression allows for models to be estimated using the fixed or random effects command. According to the Data and Statistical Services through the Princeton University Library, "fixed effects regression is the model to use when you want to control for omitted variables that differ between cases but are constant over time” (http://dss.princeton.edu/online_help/analysis/panel.htm). Fixed effects regression "is equivalent to generating dummy variables for each of your cases and including them in a standard linear regression to control for these fixed 'case effects'” (http://dss.princeton.edu/online_help/analysis/panel.htm). The random effects regression is best used "if you have reason to believe that some omitted variables may be constant over time but vary between cases, and others may be fixed between cases but vary over 
time, then you can include both types by using random effects”

(http://dss.princeton.edu/online_help/analysis/panel.htm).

The Hausman specification test is used to determine whether the data is best suited to be estimated using the fixed or random effects command. The Hausman test was performed upon the various models. The test produced mixed results meaning that some of the models were best estimated using random effects regression, whereas other models were best estimated using fixed effects regression. Since it is not possible to compare fixed effects and random effects models equivalently, it was decided to use the random effects regression models because this allows for the estimation of a dichotomous independent variable ${ }^{5}$. The fixed effects models does not allow for estimation of any dichotomous independent variables.

For each of the four data sets (1974-2000, Entered System Late, Rule of Law/Bureaucratic Quality, and Regime Change), various models are estimated. Model 1 explains the equation for testing the significance of the institutional index. Model 2 tests the significance of the component variables of the institutional index on the level of democratization. Models 3 and 4 replicate Models 1 and 2, but with the addition of regime change as a control variable.

Figure 4-2: Formulas for Time Series Panel Regression Models in Chapter 5

Model 1: $Y_{\text {DEM }}=\beta_{1 \text { INDEX }}+\beta_{2 \text { GNPPC }}+\beta_{3 \text { LITERACY }}+\beta_{4 \text { COLLEG }}+\beta_{5 \text { RELIGION }}-\beta_{6 M A R}+\mu$

Model 2: $Y_{\text {DEM }}=\beta_{1 \text { POLINSTVAR }}+\beta_{2 \text { GNPPC }}+\beta_{3 \text { LITERACY }}+\beta_{4 \text { COLLEG }}+\beta_{5 \text { RELIGION }}-\beta_{6 M A R}+\mu$

Model 3: $Y_{D E M}=\beta_{1 I N D E X}+\beta_{2 G N P p C}+\beta_{3 L I T E R A C Y}+\beta_{4 C O L L E G}+\beta_{5 R E L I G I O N}+\beta_{6 R E G C H}$ $-\beta_{7 M A R}+\mu$

\footnotetext{
${ }^{5}$ Both random effects and fixed effect regression tests were performed for the various models. There outputs were similar in terms of variable significance and the $\mathrm{R}^{2}$.
} 
$\begin{array}{cl}\text { Model 4: } & Y_{\text {DEM }}=\beta_{1 \text { POLINSTVAR }}+\beta_{2 \text { GNPpC }}+\beta_{3 \text { IITERACY }}+\beta_{4 \text { COLLEG }}+\beta_{5 R E L I G I O N} \\ & +\beta_{6 R E G C H}-\beta_{7 M A R}+\mu\end{array}$

The models in Chapter Five have a problem with collinearity since there are component variables that are used in both the dependent variable, the level of democratization indicator, and the institutional index, which is one of the independent variables. To account for this problem, statistical analyses are performed on two other dependent variables - the Freedom House democracy indicator and the change in the level of democratization.

\section{Explanation of Chapter 6}

Chapter 6 employs a time series panel logit that utilizes a combination of the fixed and random effects estimation techniques, in order to test the statistical significance of the theory and hypotheses proposed earlier. The logit model allows for the estimation of a dichotomous dependent variable, which in this case is the presence or absence of a states involvement in a militarized interstate dispute (MID). To predict the probability that a given state will be involved in a MID, the following models were estimated:

$$
\mathrm{P}(\mathrm{Y})=\frac{1}{1+e^{-y}}
$$

Where $\mathrm{Y}=1$ if the state was involved in a MID and 0 if the state was not involved in a MID for the given year. The models assume that $\mathrm{Y}$ is linearly related to the variables shown in Figure 4-3.

Figure 4-3: Formulas for Time Series Panel Logit Models in Chapter 6

Model 1: $Y_{\text {MID }}=\beta_{1 \text { POLITY2 }}-\beta_{2 \text { INDEX }}+\beta_{3 M A R}+\beta_{4 C A P}+\beta_{5 C O N T}+\beta_{6 A L L Y}+\mu$

Model 2: $Y_{\text {MID }}=\beta_{1 \text { POLITY2 }}-\beta_{2 \text { POLINSTVAR }}+\beta_{3 M A R}+\beta_{4 C A P}+\beta_{5 C O N T}-\beta_{6 A L L Y}+\mu$ 
Model 3. $Y_{\text {MID }}=\beta_{1 \text { POLITY2 }}-\beta_{2 \text { INDEX }}+\beta_{3 \text { MAR }}+\beta_{4 C A P}+\beta_{5 \text { CONT }}+\beta_{6 A L L Y}$

$+\beta_{7 R E G C H}+\mu$

Model 4: $Y_{\text {MID }}=\beta_{1 \text { POLITY2 }}-\beta_{2 \text { POLINSTVAR }}+\beta_{3 \text { MAR }}+\beta_{4 \text { CAP }}+\beta_{5 \text { CONT }}$

$+\beta_{6 A L L Y}+\beta_{7 R E G C H}+\mu$

With the exception of the intercept, all parameters are signed to be consistent with hypothesized effects.

The logit model allows for the generation of probabilities which indicate whether the model accurately predicts the outcome of the dependent variable, which in this instance is the presence of a MID. Predicted probabilities greater than .5 assume that a MID is present, whereas probabilities less than .499 suggest the absence of a MID.

\section{Explanation of Chapter 7}

Chapter 7 once again uses a time series panel regression, employing a combination of the fixed and random effects estimation techniques, to test the relationship between political institutions, the level of democratization, and their combined effect on armed conflict. This chapter expands upon previous research by using the Armed Conflict data set which includes external and internal conflicts.

Figure 4-4: Formulas for Time Series Panel Regression Models in Chapter 7

Model 1: $Y_{\text {CONFLICT }}=\beta_{1 \text { POLITY2 }}-\beta_{\text {2INDEX }}+\beta_{3 M A R}+\beta_{4 C A P}+\beta_{5 C O N T}+\beta_{6 A L L Y}+\mu$

Model 2: $Y_{\text {CONFLICT }}=\beta_{1 \text { POLITY2 }}-\beta_{2 \text { POLINSTVAR }}+\beta_{3 \text { MAR }}+\beta_{4 \text { CAP }}+\beta_{5 \text { CONT }}-\beta_{6 A L L Y}+\mu$

Model 3: $Y_{\text {CONFLICT }}=\beta_{1 \text { POLITY2 }}-\beta_{2 \text { INDEX }}+\beta_{3 M A R}+\beta_{4 C A P}+\beta_{5 \text { CONT }}+\beta_{6 A L L Y}$

$$
+\beta_{7 R E G C H}+\mu
$$

Model 4: $Y_{\text {CONFLICT }}=\beta_{1 \text { POLITY2 }}-\beta_{2 \text { POLINSTVAR }}+\beta_{3 \text { MAR }}+\beta_{4 \text { CAP }}+\beta_{5 \text { CONT }}$

$$
+\beta_{6 A L L Y}+\beta_{7 R E G C H}+\mu
$$




\section{Case Selection}

In the Polity IV data set, Marshall and Jaggers (2000) define coherent democracies as those states which receive a regime type, or polity score, greater than six, coherent autocracies as states whose regime score is less than negative six, and define all remaining states as anocracies. However, they provide little theoretical justification for their classification of democracies, autocracies, and anocracies. The cases were selected according to Gurr, Jaggers, and Moore’s definition of anocracies. Therefore, anocracies are defined as those states whose polity score ranges from -6 to +6 . States were included in this quantitative research if they were categorized as anocracies for three consecutive years.

\section{Variables}

\section{Dependent Variables}

Level of Democratization

In order to gauge the level of democratization for the countries of interest, the “Polity IV Project: Political Regime Characteristics and Transitions” dataset is utilized. Marshall and Jaggers combine annual measures of the competitiveness of executive recruitment, the openness of executive recruitment, constraints on the chief executive, and competitiveness of political participation to create an eleven-point scale of the country’s democratic and autocratic characteristics. These two indicators are then combined to produce a third indicator, the polity score, which is derived by subtracting the autocratic score from the democratic score. This produces a single regime score which ranges from +10 (fully democratic characteristics) to a -10 (fully autocratic 
characteristics. This twenty-one-point polity score indicator is used to operationalize the level of democratization.

\section{Freedom House Democracy Indicator}

Due to the collinearity problem that exists within Chapter Five between the dependent variable, the level of democratization assessed by the Polity2 variable, and the institutional index, it is necessary to use other dependent variables to be certain that the initial results produced are accurate. The first of two alternative dependent variables is the Freedom House Democracy Indicator. The Freedom House data is based upon two categories: political rights and civil liberties. According to the Freedom in the World Survey Methodology (2003),

political rights enable people to participate freely in the political process. This includes the right to vote and compete for public office and to elect representatives who have a decisive vote on public policies. Civil liberties include the freedom to develop opinion, institutions, and personal autonomy without interference from the state.

These two broad categories are assessed on a seven-point scale ranging from the most to the least democratic. The political rights and civil liberties variables are then combined to produce the democracy indicator. This democracy indicator is a scale ranging from one to fourteen, with one being the least democratic and fourteen being the most democratic.

\section{Change in the Level of Democratization}

Due to contamination, the second alternative dependent variable is the change in the level of democratization. This dependent variable is used to see if the political institutions function consistently and to gain other insights. In order to gauge the change in the level of democratization, the Polity2 score is used from the Polity IV Project. Each 
state's twenty-one point polity score indicator is subtracted from the previous years score. This number indicates the state's change in the level of democratization from one year to the next. The number measures changes in the positive (democratic) direction and changes in the negative (authoritarian) direction.

\section{Militarized Interstate Disputes}

The first model to be tested remains consistent with previous research. The model employs the Correlates of War (COW) Project Militarized Interstate Dispute (MID) dataset as the dependent variable. The dataset's definition of a militarized interstate dispute "refers to historical cases in which the threat, display, or use of military force by one member state is explicitly directed t owards the government, official representatives, official forces, property, or territory of another state” (Jones, Bremer, and Singer 1996, p. 168). Based upon the MID dataset, a dichotomous variable called MID involvement is constructed based upon the hostility level. Hostility levels range from the lack of militarized action, the threat to use force, the display of force, the use of force, and at the extreme, war. If a state was involved in any type of militarized interstate dispute, it is coded as a one. If the state was not involved in a militarized interstate dispute, it receives a score of zero.

\section{Armed Conflict Dataset}

Although previous research has used the Correlates of War (COW) Militarized Interstate Dispute (MID) dataset, this chapter employs the “Armed Conflict Dataset 1946-2001,” which was compiled by Nils Peter Gleditsch, et al. (2002). Previous research has limited the analyses by using a logit model and only applying the analysis to external conflict. Through the use of the Armed Conflict Dataset, previous research can 
be expanded upon through the use of a time series panel regression and applying the analysis to external as well as internal conflict.

The dataset's definition of armed conflict is "a contested incompatibility that concerns government or territory or both where the use of armed force between two parties results in at least 25 battle-related deaths. Of these two parties, at least one is the government of a state” (Gleditsch 2002, p. 618-19). A state is defined as “an internationally recognized sovereign government controlling a specified territory, or a non-recognized government whose sovereignty is not disputed by another internationally recognized sovereign government previously controlling the same territory” (Gleditsch 2002, p. 619).

The dependent variable measures the intensity level of conflict which was coded along four categories. A zero indicates the lack of conflict. A one signifies a minor conflict which indicates that more than 25 battle-related deaths have occurred for every year in the period. A two designates an intermediate conflict. This suggests that more than 25 battle-related deaths have occurred per year and a total of more than 1,000 battlerelated deaths have occurred over the conflict history. A three specifies a war which is operationalized as more than 1,000 battle-related deaths per year for every year of the conflicts history.

\section{Independent Variables}

\section{Institutional Index}

There are a total of thirteen independent variables which measure the different political institutions. Because it is not possible to perform statistical analyses on such a large number of independent variables, due to the reduction in the available degrees of 
freedom, the measures for the political institutions have been aggregated into an institutional index. All thirteen variables have been recoded on a common scale. ${ }^{6}$ A zero to twelve-point scale is used for each variable, which is necessary so that one variable is not weighed more than another in the institutional index. Higher index scores indicate a greater level of institutionalization, whereas lower scores suggest a more elementary level of institutional development.

Component Variables of the Institutional Index

\section{Executives}

In order to ascertain the role of the executive, two variables are utilized from the Polity IV dataset. These variables include the openness of the executive recruitment and the constraints placed on the chief executive.

First, the openness of the executive recruitment determines the extent to which "all the politically active population has an opportunity, in principle, to attain the position through a regularized process” (Marshall and Jaggers 2000, p. 19). Four categories are used to operationalize this variable. A one indicates a closed system in which chief executives are determined through hereditary succession. A two signifies regimes that maintain a dual executive, in which a hereditary ruler shares power with an appointed governing minister. A three denotes a dual executive system in which power is shared by a hereditary ruler in addition to an elected governing minister. Regimes are coded as four if they are categorized as having an open system of recruitment, regardless of whether the executive is elected or selected through some other regularized process.

Secondly, a seven-point scale is used to determine the "institutionalized constraints on the decision-making powers of the chief executive” (Marshall and Jaggers

\footnotetext{
${ }^{6}$ See Appendix 3 for the institutional index recoding schemes.
} 
2000, p. 21). Regimes receive a score of one or two (the intermediate category) if they support executives that have unlimited authority. A three or four (the intermediate category) indicates regimes that place slight to moderate limitations on executive authority. Regimes that place substantial limitations on executive authority are coded as a five or six (the intermediate category). Finally, a seven indicates regimes in which the executive branch has parity with or are subordinate to accountability groups.

\section{Legislatures}

Two variables from the Cross National Time Series Dataset are used to operationalize the role of the legislative branch. The first variable refers to legislative effectiveness and is categorized on a four-point scale. A zero indicates that a legislature does not exist. A one represents an ineffective legislature. "There are three possible bases for this coding: first, legislative activity may be essentially of a 'rubber stamp' character; second, domestic turmoil may make the implementation of legislation impossible; third, the effective executive may prevent the legislature from meeting, or otherwise substantially impede the exercise of its functions” (Banks, CNTS). A two indicates that the legislature is partially effective. This is a situation in which the power of the executive outweighs the legislative branch, but does not completely dominate the legislature. Finally, an effective legislature receives a three. An effective legislature is characterized by "the possession of significant governmental autonomy by the legislature, including, typically, substantial authority in regard to taxation and disbursement, and the power to override executive vetoes of legislation” (Banks, CNTS).

The second variable refers to the method of legislative selection. A zero once again indicates that a legislature does not exist. A one denotes a non-elective legislature. 
"Examples would be the selection of legislators by the effective executive, or by means of heredity or ascription” (Banks, CNTS). A two designates an elective legislature. Elective legislatures "(or members of the lower house in a bicameral system) are selected by means of either direct or indirect popular election” (Banks, CNTS).

\section{Judiciary}

The judiciary is measured through a rule of law variable which is collected from Stephen Knack and Philip Keefer's IRIS III dataset. Rule of law reflects "the degree to which the citizens of a country are willing to accept the established institutions to make and implement laws and adjudicate disputes” (Knack, IRIS III). The variable is operationalized on a zero to six-point scale. Higher scores indicate "sound political institutions, a strong court system, and provisions for an orderly succession of power” (Knack, IRIS III). Lower scores designate “a tradition of depending on physical force or illegal means to settle claims" (Knack, IRIS III). The data for the rule of law variable is only available for the years 1982 through 1997.

\section{Bureaucracy}

Bureaucratic quality is measured on a zero to six-point scale which is attained from the IRIS III dataset. Higher scores are symbolic of "an established mechanism for recruitment and training, autonomy from political pressure, and strength and expertise to govern without drastic changes in policy or interruptions in government services” (Knack, IRIS III). Higher scores represent a more professionalized and meritorious bureaucracy. Lower scores indicate the lack of a professional bureaucracy and one that is based on political patronage. The data for the bureaucratic quality variable is only available for the years 1982 through 1997. 


\section{Constitutional Checks}

Constitutional checks, which is attained from the Database of Political Institutions, is an indirect measure of a state's constitutional checks and balances. ${ }^{7}$ This is an incremental number with higher numbers indicating the more checks that are in place. The measure accounts for checks that are placed on the executive and legislative branches, as well as the role of opposition political parties.

\section{Political Parties}

In order to operationalize the role of political parties, a variable measuring party legitimacy is used. A zero indicates that political parties do not exist, or all but the dominant party is excluded from political participation. A one represents significant exclusion of parties. A two denotes that "one or more minor or 'extremist' parties are excluded” (Banks, CNTS). Finally, a three suggests that no political parties are excluded from participation. This measure was collected from the Cross National Time Series Data.

\section{Regime Type}

A three-point scale is used to operationalize the role of the military in politics. A one denotes a civilian government in which the military plays a subordinate role. A two signifies a military-civilian government in which the government is outwardly civilian, but effectively controlled by a military elite. Finally, a three indicates a military government in which there is direct military control. This information was collected from the Cross National Time Series Data.

\footnotetext{
${ }^{7}$ Constitutional checks is the only independent variable that is not recoded for use in the institutional index because it is not a nominal number.
} 


\section{Press Freedom}

Two different datasets are used to measure the level of press freedom. First, Douglas Van Belle compiled a comprehensive dataset which measures global press freedom. The data covers an extended time frame for all of the states in the Polity III dataset. For this research, Van Belle’s data will be used to measure press freedom for the years 1974 through 1995.

Van Belle operationalizes press freedom according to five different categories. A zero indicates that the press is nonexistent or the information is too little to code. A one signifies that the press is free, meaning that the press is capable of operating as an arena of political competition. A two represents an imperfectly free press. This means that the freedom of the press is somewhat compromised, yet it can still operate as an arena of political competition. A three indicates that the press is restricted, which suggests that the press is not under direct government control, however it is not capable of functioning as an arena of political debate. Finally, a four represents a controlled press. This final category suggests that the press is directly controlled by the government or strictly censored.

For the final years of interest, press freedom data is collected from Freedom House. Freedom House uses a 100-point scale to measure press freedom. The data is operationalized according to three categories. First, a zero to thirty indicates a free press. Second, a thirty-one to sixty signifies a partly free press. Finally, a sixty-one to 100 indicates a press that is not free. The Freedom House data was collapsed according to the five levels of the Van Belle dataset. ${ }^{8}$

\footnotetext{
${ }^{8}$ The Freedom House data was collapsed to merge with the Van Belle data according to the following guidelines: $0-25=1,26-50=2,51-75=3,76-100=4$.
} 
Although it is never ideal to combine two data sets that have slightly different coding rules, their merger allows for the inclusion and estimation of press freedom for the entire time frame of interest to this dissertation.

\section{Electoral System}

The information regarding the type of electoral system is collected from the "Database of Political Institutions.” A trichotomous variable delineates the type of system. A zero indicates that the system has an un-elected executive. A zero also denotes a presidential system in which the chief executive is either directly elected or elected by an electoral college. ${ }^{9}$ A one represents a presidential system where an assembly elects the chief executive. Finally, a two denotes a parliamentary system.

\section{Free and Fair Elections}

\section{A dichotomous variable, constructed from Polity IV's competitiveness of} executive recruitment, is used to measure the concept of free and fair elections. If states are coded as participating in competitive elections, they are assigned the score or one. Those states that do not participate in competitive elections receive a score of zero. Competitive elections are deemed to be free and fair by independent observers, elections outcomes are not predisposed, opposition parties are allowed to compete in the process, and the election is free from repression. If the chief executive is indirectly selected, then the electoral body must be freely elected.

\footnotetext{
${ }^{9}$ According to this variable in the Database of Political Institutions, both un-elected executives and presidential systems are coded as a one. However, through the examination of another variable (the Executive Index of Political competitiveness) it is possible to differentiate which systems maintain an unelected executive and which systems are presidential. This is accounted for in the recoding scheme for the electoral system variable.
} 


\section{Universal Suffrage}

A dichotomous variable operationalizing universal suffrage is colleted from the Europa World Year Book. Universal suffrage suggests that any citizen over the age of 18 cannot be denied the right to vote. A zero indicates that suffrage is not extended to all groups. A one indicates that suffrage is extended to all segments of the citizenry.

\section{Control Variables}

\section{Gross National Product (per capita)}

Gross national product, the broadest measure of national income, was derived from the World Development Report's World Development Indicators. ${ }^{10}$ Gross national product is the sum of two components - the gross domestic product and net income from abroad. GDP measures the final output of goods and services produced by the domestic economy. Net income from abroad is income in the form of compensation of employees, interest on loans, profits, and other factor payments that residents receive from abroad, less payments made for labor and capital. Most countries estimate GDP by the production method. This method sums the final outputs of the various sectors of the economy (e.g., agriculture, manufacturing, and government services), from which the values of the inputs to production have been subtracted. GNP estimates in U.S. dollars are calculated according to The World Bank Atlas methodology. GNP estimates in local currencies were converted to U.S. dollars using a three-year average exchange rate, adjusted for domestic and U.S. inflation. The Atlas method of averaging three years of exchange rates smoothes fluctuations due to the currency market and provides a more reliable measure, over time, of overall income than do estimates based on a single year's exchange rate.

\footnotetext{
10 The World Development Report was not published in 1996 and 1998 . Therefore, the data from the previous year was used.
} 
Per capita estimates of gross national product are calculated using mid-year population data.

\section{Literacy}

The data for the literacy rate estimate is attained from the United Nations Educational, Scientific, and Cultural Organization's Institute for Statistics. The literacy rate refers to the adult aged population (aged 15 and older) who can both read and write. $^{11}$

\section{Colonial Legacy}

Colonial legacy is measured as a dichotomous variable. If the state is a former British colony, it is coded as a one. Otherwise, the state receives a value of zero. This information is attained from the Europa World Year Book.

\section{Religion}

Religion is measured as a dichotomous variable that is assessing whether a majority of the state's citizens are followers of a Protestant religion. If the state is predominately Protestant, it was coded as a one. If the state predominately practiced any other type of religion, it received a score of zero. This information is collected from the Europa World Year Book.

\section{Regime Change}

The data on regime change was collected from a dataset compiled by Joe Hagan for the article titled "Domestic political regime changes and Third World voting

\footnotetext{
${ }^{11}$ The data provided by UNESCO is only an estimate of literacy rates. In addition, the data is provided at five-year intervals.
} 
realignments in the United Nations.”12 This comprehensive dataset explains regime change "as a change occurring in the central leadership body" (Hagan 1989 508). Using a five-point classification scheme which ranges from mild to dramatic changes, Hagan produces a more detailed assessment of the severity of regime changes.

A one identifies "a change in the effective head of state, but it does not alter the regime’s basic political makeup in terms of its component factions or parties” (Hagan 1989 508). A two signifies that "there is a change in the leadership body in terms of its component factions (in the case of fragmented single-party regimes) or in terms of parties or other autonomous political groups (in the case of coalitions)” (Hagan 1989 508). A three designates a regime change characterized by "a replacement of the entire ruling group or coalition by another group from the same end of the established political spectrum” (Hagan 1989 508). A four designates a more severe regime change in which "there is a replacement of the entire ruling group or coalition by another group from the opposite end of the established political spectrum” (Hagan 1989 508). Finally, a five signifies the most dramatic regime change which is characterized by "a revolutionary transformation in which a group is replaced by an 'antisystem' group that fundamentally restructures the political system” (Hagan 1989 508).

\footnotetext{
${ }^{12}$ The data provided by Joe Hagan was only available through the year 1985 . Wituski provided more recent data, using the same coding rules for regime change. This newer version of the data covers the years 1986 through 1992.
} 


\section{Conflict Control Variables ${ }^{13}$}

It is necessary to employ conflict control variables to account for a state reacting to both internal and external events that may cause conflict, such as the number of minority at risk groups that are located within the state, state capabilities, the number of contiguous relationships, and alliance memberships. These are traditional conflict control variables that can cause any state to become involved in conflict situations; however, these impacts can be intensified for states that are involved in the democratization process.

\section{Minorities at Risk}

The number of minority groups at risk was collected from the Minorities at Risk Project dataset, which was compiled by the Center for International Development and Conflict Management at the University of Maryland. The Minorities at Risk Project is a detailed, empirical study of ethno-political groups around the globe. Minority groups were included in the dissertation dataset if they meet at least one of the four following criteria - the minority group is subject to political, economic, or social discrimination, the group is disadvantaged from previous discrimination, an advantaged minority group being challenged, or the minority group supports political organizations advocating greater collective rights.

\section{State Capabilities}

The Composite Indicator of National Capability (CINC) score is an index of a state's proportion of total system capabilities. This index was collected from the National Material Capabilities Data Set that is part of the Correlates of War Project. This index is

\footnotetext{
${ }^{13}$ Most conflict variables are constructed in a dyadic format; however, that is not appropriate for this dissertation research.
} 
based upon six component variables - military personnel, military expenditure, total population, urban population, iron and steel production, and energy consumption. The CINC score is the most widely used indicator of national capabilities and serves as an indirect measure of a state's power. The CINC score is calculated by summing all observations on each of the six capability component variables for a given year, converting each state's total component to a share of the international system, and then averaging across the six components.

The first component variable, military personnel, is explained "as troops under the command of the national government, intended for use against foreign adversaries, and held ready for combat as of January 1 of the referent year” (Correlates 2005 8). Military expenditure, the second component variable, is defined simply "as the total military budget for a given states for a given year” (Correlates 2005 16). Total population attempts to capture the sheer number of people within a state based upon a state's census information. Total population, it is theorized, allows a state with a larger population to "have a larger army, maintain its home industries during times of war, and absorb losses in wartime easier than a state with a smaller population” (Correlates 2005 21). Urban population, the fourth component variable, serves to measure more intangible concepts. "Urbanization is associated with higher education standards and life expectancies, with industrialization and industrial capacity, and with the concentrated availability of citizens who may be mobilized during times of conflict” (Correlates 2005 27). Urban population depicts the number of cities per state that have populations over 100,000. Iron and steel production, the fifth component variable, measures the amount of iron and steel produced in a given state (in thousands of tons) for the referent year. The amount of iron and steel 
produced indicates the level of industrial capacity in the state. The final component variable, Primary Energy Consumption (PEC), is also a measure of industrial capacity since "the greater the energy consumption, the larger the potential manufacturing base of an economy, the larger the potential economy of the state in question, and the more wealth and potential influence that state could or should have" (Correlates 2005 42). PEC is derived from four sources - coal, petroleum, electricity, and natural gas. The data is presented in thousands of coal-ton equivalents. As previously stated, these six component variables are combined to produce the CINC score.

\section{Contiguity}

Collected from the Direct Contiguity data set of the Correlates of War Project, the contiguity variable identifies all direct contiguity relationships between states in the international system. Although most contiguity data is dyadic, that format is not appropriate for this research. Therefore, for each state of interest to the dissertation research, the number of land and water contiguities is presented for the states of interest. The contiguity classification system is made up of five categories. One category represents land contiguity and the remaining four signify water contiguity. The water contiguity classification system is "divided into four categories, based on the distances of 12, 24, 150, and 400 miles” (Stinnett 2002). Although 400 miles seems like a great distance, " 400 miles is the maximum distance at which two 200 mile exclusive economic zones can intersect” (Stinnett 2002). The variable is coded such that a zero indicates that a state lacks contiguity, a one signifies that a state is contiguous with one other state, and so on. The variable does not have an upper limit. 


\begin{abstract}
Alliances
The alliance control variable was collected through the Expected Utility Generation and Data Management Program (EUGene), but the original data is from the Correlates of War Formal Interstate Alliance Data Set. This data set codes three types of alliances based upon their level of commitment. A Type I alliance, or a defense pact, obligates states to militarily intervene on behalf of any member state that is attacked. The neutrality or non-aggression pact, a Type II alliance, is a pledge to remain militarily neutral if any member state is attacked. Finally, the Type III alliance, or ententes, promise consultation and/or cooperation in a time of crisis, which includes a military attack. The variable is coded such that a zero indicates that a state does not participate in any formal alliances, a one indicates that the state is a member of one alliance, and so on. There is not an upper limit for this variable.

The various dependent, independent, and control variables allows for statistical analyses to be performed which will provide the answers to the research questions and hypotheses. The four different data sets provide for the estimation of different time frames, states, and variables. Overall, this will offer the most inclusive assessment of the data and will determine which political institutions are critical to democratic consolidation and the prevention of armed conflict.
\end{abstract}




\section{Chapter 5 - Level of Democratization}

\section{Introduction}

Chapter five is the first of three quantitative chapters needed to test the

hypotheses and answer the pertinent research questions to this dissertation. A two-stage analysis is necessary to test the relationship between political institutions, the level of democratization, and their collective effect on conflict. This chapter examines the first stage of the analysis by testing the impact that political institutions have on democratic consolidation. This chapter test two hypotheses:

H1. States that are making the transition to democracy while establishing strong political institutions, as evidenced by a higher institutional index score, are more likely to consolidate democracy.

H3. Governmental institutions have a greater positive influence on democratic consolidation than intermediary institutions.

To test these hypotheses, a time series panel regression, with the fixed effects command, is used for the four data sets - 1974 through 2000, Entered System Late, Rule of Law / Bureaucratic Quality, and Regime Change.

A correlation matrix is presented for each of the four data sets because collinearity is a problem between the dependent variable, the level of democratization, measured by the Polity 2 score, and the institutional index. The Polity 2 score and the institutional index share some of the same component variables, which explain the high level of collinearity. ${ }^{14}$

\footnotetext{
${ }^{14}$ Thought was given to using change in the level of democratization as the dependent variable for this chapter. However, it was determined that, regardless of collinearity, the level of democratization was the proper dependent variable for theoretical reasons. The empirical results for the change in the level of democratization are briefly discussed in the conclusion of this chapter. The results for each data set for the change in the level of democratization can be found in Appendix 3.
} 


\section{Results}

$1974-2000$

The first data set to be analyzed, 1974 through 2000, returns significant results supportive of the institutional threshold theory. However, Table 5-1 presents a correlation matrix for the level of democratization and the institutional index which suggests that collinearity is a problem within this model. This indicates that the high $\mathrm{Z}$ value associated with the institutional index can be attributed to collinearity. However, the importance of the institutional index in democratic consolidation should not be understated.

Table 5-1.

Correlation Matrix between the Level of Democratization and the Institutional Index 1974 through 2000

\begin{tabular}{c|cc} 
& Level of Democratization & Index \\
\hline Level of Democratization & 1.0000 & \\
Index & 0.7780 & 1.0000
\end{tabular}

As Table 5-2 explains, the institutional index returns a significant result suggesting that democratic consolidation will occur as political institutions increase in legitimacy providing support for the institutional threshold theory. The gross national product per capita variable returns results indicating that as the level of wealth per capita increases, the level of democratization will also increase. The next variable to receive significant results is literacy indicating that as the adult population becomes more literate, the level of democratization will increase. These results lend support to the literature suggesting that a threshold effect regarding GNP per capita and literacy rates is necessary for democratic consolidation.

The remaining variables do not return significant results. Colonial legacy produces evidence contrary to the political development literature. This literature 
suggests that former British colonies are at an advantage to consolidate democracy; however, this model supplies contrary results. The religion variable is also contrary to political development literature which suggests that predominately Protestant states are more likely to consolidate democracy. However, these results suggests that Protestant religions are not advantaged over any other type of religion in the process of democratic consolidation. The minorities at risk variable generates counter-intuitive results which suggest that as the number of minority at risk groups within a state increase, the level of democratization will also increase.

Overall, this model performs well with fifty-six percent of the variation within the data being explained, according to the $\mathrm{R}^{2}$ score. The three pertinent independent variables, the institutional index, GNP per capita, and the literacy rate, all return results consistent with hypothesized effects. 
Table 5-2. Time Series Panel Regression for the Level of Democratization 1974 through 2000 Full Model

\begin{tabular}{|l|l|l|l|}
\hline \multicolumn{1}{|c|}{ Variable } & \multicolumn{1}{|c|}{ Coefficient } & \multicolumn{1}{|c|}{ Standard Error } & \multicolumn{1}{|c|}{ Z Value } \\
\hline Index & .1631886 & .0033653 & $48.49^{* * * *}$ \\
\hline GNP per capita & .000131 & .0000431 & $3.04^{* * *}$ \\
\hline Literacy & .0561202 & .0071838 & $7.81^{* * * *}$ \\
\hline Colonial Legacy & -.1553441 & .827068 & -0.19 \\
\hline Religion & -1.298377 & 1.190151 & -1.09 \\
\hline Minorities at Risk & .0592063 & .1710867 & 0.35 \\
\hline Constant & -15.81278 & .6462727 & $-24.47^{* * * *}$ \\
\hline
\end{tabular}

$\mathrm{n}=70$ cases, 1890 observations

Overall $\mathrm{R}^{2}=0.5694$

${ }^{*} \mathrm{p} \leq .10$, one-tailed test

$* * \mathrm{p} \leq .05$, one-tailed test

$* * * \mathrm{p} \leq .01$, one-tailed test

$* * * * \mathrm{p} \leq .001$, one-tailed test

Table 5-3 displays the results for the component variables of the institutional index for the 1974 through 2000 model. The $\mathrm{Z}$ values are inflated due to collinearity between the component variables of the institutional index and the level of democratization indicator, the Polity 2 score. All variables produce significant results ranging from .05 to .001 . The component variables coefficients demonstrate that minor positive changes in the institutional performance will lead to an increase in the level of democratization.

Both variables used to measure the executive branch are highly significant. The constraints on the chief executive receives the highest $\mathrm{Z}$ value of the eleven component variables tested in the model, implying the importance of constraining the chief executive through accountability groups in order for democratic consolidation to occur. Second, 
states that possess an open system of executive recruitment are more likely to consolidate democracy.

Two variables are also used to determine the role of the legislative branch in democratic consolidation. Those states which possess an effective legislature, which is characterized by autonomy and the ability to override executive vetoes of legislation, are more likely to consolidate democracy. Also, states that are able to either directly or indirectly popularly elect their legislative representation are more likely to consolidate democracy.

Constitutional checks are used as an indirect measure of the state's constitutional checks and balances. The model returns evidence to suggest that the more checks and balances that are placed on the legislative and executive branches will allow for democratic consolidation. States that possess a civilian government, in which the military plays a subordinate role, are more likely to consolidate democracy. Consistent with previous literature on democratization, the electoral system variable provides results demonstrating that a parliamentary system will more likely produce democratic consolidation than either a presidential or hybrid type of electoral system.

Four intermediary institutions are tested within this model. The party legitimacy variable explains that including opposition political parties within the political arena will lead to democratic consolidation faster than excluding parties or only allowing for the dominant party to participate in the political arena. Freedom of the press, meaning that the press is capable of operating as an arena of political competition, is a necessary component to democratic consolidation. Universal suffrage receives the weakest $\mathrm{Z}$ value; however, there is evidence to suggest that universal suffrage, or the granting of voting 
privileges to all adult segments of the society, is basic to democratic consolidation.

Finally, the free and fair elections variable provides results demonstrating that competitive elections are vital to the process of democratic consolidation.

The 1974 through 2000 model tests the entire time frame of interest to this dissertation, but does so for a reduced number of states. These component variable models perform well which their high R2 scores substantiate.

Table 5-3. Time Series Panel Regression for Level of Democratization 1974 through 2000 Institution Variables

\begin{tabular}{|l|l|l|l|l|}
\hline \multicolumn{1}{|c|}{ Variable } & \multicolumn{1}{|c|}{ Coefficient } & \multicolumn{1}{c|}{$\begin{array}{c}\text { Standard } \\
\text { Error }\end{array}$} & \multicolumn{1}{|c|}{$\mathbf{Z}$ Value } & \multicolumn{1}{|c|}{ Overall R $\mathbf{~}^{2}$} \\
\hline $\begin{array}{l}\text { Openness of Exec. } \\
\text { Recruitment }\end{array}$ & .4862621 & .0262011 & $18.56^{* * * *}$ & 0.2105 \\
\hline $\begin{array}{l}\text { Constraints on the } \\
\text { Chief Executive }\end{array}$ & 1.268105 & .0184267 & $68.82^{* * * *}$ & 0.7195 \\
\hline $\begin{array}{l}\text { Legislative } \\
\text { Effectiveness }\end{array}$ & 1.059095 & .0348587 & $30.38^{* * * *}$ & 0.3801 \\
\hline $\begin{array}{l}\text { Legislative } \\
\text { Selection }\end{array}$ & .27487 & .02477 & $11.10^{* * * *}$ & 0.1861 \\
\hline $\begin{array}{l}\text { Constitutional } \\
\text { Checks }\end{array}$ & 2.251204 & .0813734 & $27.67^{* * * *}$ & 0.4320 \\
\hline $\begin{array}{l}\text { Military } \\
\text { Electoral System }\end{array}$ & .4477974 & .0320501 & $13.97^{* * * *}$ & 0.1975 \\
\hline Party Legitimacy & .8170248 & .0343015 & $19.87^{* * * *}$ & 0.3159 \\
\hline Press Freedom & .8507744 & .0352355 & $24.15^{* * * *}$ & 0.3524 \\
\hline $\begin{array}{l}\text { Free and Fair } \\
\text { Elections }\end{array}$ & .8318189 & .0189572 & $43.88^{* * * *}$ & 0.5699 \\
\hline Universal Suffrage & .2057506 & .0829641 & $2.48^{* * *}$ & 0.1575 \\
\hline
\end{tabular}

$\mathrm{n}=70$ cases, 1890 observations

${ }^{*} \mathrm{p} \leq .10$, one-tailed test

${ }^{* *} \mathrm{p} \leq .05$, one-tailed test

$* * * \mathrm{p} \leq .01$, one-tailed test

$* * * * \mathrm{p} \leq .001$, one-tailed test 


\section{Entered System Late}

Once again, collinearity is a problem in the Entered System Late data set because of the shared values that exist between the institutional index and the level of democratization indicator. Table 5-4 provides a correlation matrix that details the high level of collinearity between the variables.

Table 5-4.

Correlation Matrix between the Level of Democratization and the Institutional Index Entered System Late

\begin{tabular}{c|cc} 
& Level of Democratization & Index \\
\hline Level of Democratization & 1.0000 & \\
Index & 0.7695 & 1.0000
\end{tabular}

The full model for the Entered System Late data set produces supporting evidence for the institutional index and therefore the institutional threshold theory, but does not provide overwhelming evidence for the thresholds regarding wealth and education. The institutional index is once again strongly significant signifying the importance of political institutions in increasing the level of democratization within a state. Gross national product per capita is not significant, although it does suggest that the level of democratization will rise with an increase in per capita wealth. The literacy rate also does not produce significant results, but it does provide evidence for the literacy rate threshold, which serves as a proxy for education, indicating that the level of democratization will increase with the literacy rate.

A significant result is received for the colonial legacy variable providing further evidence that a history of British colonialism does not advantage the state in the course of democratic consolidation. The religion model returns different results than the 1974 through 2000 data set. In this data set, the religion variable suggests that a predominately 
Protestant state will be more likely to consolidate democracy; however, the result is not significant. Finally, although not statistically significant, the minorities at risk variable produces results consistent with conventional wisdom signifying that as the number of minority at risk groups within a state decrease, the level of democratization will increase.

Table 5-5. Time Series Panel Regression for Level of Democratization Entered System Late Full Model

\begin{tabular}{|l|l|l|l|}
\hline \multicolumn{1}{|c|}{ Variable } & \multicolumn{1}{|c|}{ Coefficient } & \multicolumn{1}{|c|}{ Standard Error } & \multicolumn{1}{|c|}{ Z Value } \\
\hline Index & .1330936 & .005322 & $25.01^{* * * *}$ \\
\hline GNP per capita & .0000556 & .0000678 & 0.82 \\
\hline Literacy & .0119677 & .0111683 & 1.07 \\
\hline Colonial Legacy & -1.346236 & .8535777 & $-1.58^{*}$ \\
\hline Religion & 1.446682 & 1.138932 & 1.27 \\
\hline Minorities at Risk & -.0920159 & .161536 & -0.57 \\
\hline Constant & -9.471771 & .8900626 & $-10.64^{* * * *}$ \\
\hline
\end{tabular}

$\mathrm{n}=87$ cases, 870 observations

Overall $\mathrm{R}^{2}=0.5855$

${ }^{*} \mathrm{p} \leq .10$, one-tailed test

$* * \mathrm{p} \leq .05$, one-tailed test

$* * * \mathrm{p} \leq .01$, one-tailed test

$* * * * \mathrm{p} \leq .001$, one-tailed test

Once again, all of the component variables of the institutional index are statistically significant ranging from .10 to .001 . These models perform suitably, as their overall $\mathrm{R}^{2}$ scores demonstrate.

Presented in Table 5-6, of the eleven component variables analyzed in this model, constraints on the chief executive is the best performer specifying the need to limit executive authority and maintain executive parity with other branches of the government. Free and fair elections perform well with a highly significant result, once again 
demonstrating the need for competitive elections that are deemed to be free and fair by independent observers. Third, the strength of the legislative effectiveness variable indicates the need for an effective legislature that can serve as a check on the executive branch. Fourth, the openness of executive recruitment variable suggests that if the politically active population has an opportunity to compete for the chief executive, the level of democratization will increase. Further evidence is attained demonstrating that the inclusion of opposition political parties will serve to foster democratic consolidation. The sixth variable in decreasing order of statistical significance, the role of the military, produces evidence that democratic consolidation is more likely to occur under civilian governments rather than governments in which there is direct military control. Constitutional checks, the eight variable, suggests that restraining the power of the branches of government through checks and balances will produce democratic consolidation. The electoral system variable provides further evidence that a parliamentary system is more likely to produce democratic consolidation. The next to last variable in statistical significance is press freedom. This does suggest, however, that press freedom is needed to provide for an open debate arena which is a critical element for democratic consolidation. Finally, universal suffrage receives the least support. However, the variable is still significant indicating that all adults should be awarded suffrage in an attempt to produce democratic consolidation. 
Table 5-6. Time Series Panel Regression for Level of Democratization Entered System Late Institution Variables

\begin{tabular}{|l|l|l|l|l|}
\hline \multicolumn{1}{|c|}{ Variable } & \multicolumn{1}{|c|}{ Coefficient } & \multicolumn{1}{c|}{$\begin{array}{c}\text { Standard } \\
\text { Error }\end{array}$} & \multicolumn{1}{|c|}{$\mathbf{Z}$ Value } & \multicolumn{1}{|c|}{ Overall $\mathbf{R}^{2}$} \\
\hline $\begin{array}{l}\text { Openness of Exec. } \\
\text { Recruitment }\end{array}$ & .4734754 & .0334296 & $14.16^{* * * *}$ & 0.2523 \\
\hline $\begin{array}{l}\text { Constraints on the } \\
\text { Chief Executive }\end{array}$ & 1.006265 & .0323295 & $31.13^{* * * *}$ & 0.6882 \\
\hline $\begin{array}{l}\text { Legislative } \\
\text { Effectiveness }\end{array}$ & .8547808 & .054009 & $15.83^{* * * *}$ & 0.3859 \\
\hline $\begin{array}{l}\text { Legislative } \\
\text { Selection }\end{array}$ & .3001504 & .0335852 & $8.94^{* * * *}$ & 0.1697 \\
\hline $\begin{array}{l}\text { Constitutional } \\
\text { Checks }\end{array}$ & .7612387 & .0964554 & $7.89^{* * * *}$ & 0.2967 \\
\hline $\begin{array}{l}\text { Military } \\
\text { Electoral System }\end{array}$ & .4137991 & .0411599 & $10.05^{* * * *}$ & 0.1891 \\
\hline Party Legitimacy & .337262 & .0453775 & $6.72^{* * * *}$ & 0.2592 \\
\hline Press Freedom & .145379 & .0359362 & $4.05^{* * * *}$ & 0.1911 \\
\hline $\begin{array}{l}\text { Free and Fair } \\
\text { Elections }\end{array}$ & .5358527 & .0239719 & $22.35^{* * * *}$ & 0.5205 \\
\hline $\begin{array}{l}\text { Universal } \\
\text { Suffrage }\end{array}$ & .1828592 & .1416975 & $1.29^{*}$ & 0.1331 \\
\hline
\end{tabular}

$\mathrm{n}=87$ cases, 870 observations

${ }^{*} \mathrm{p} \leq .10$, one-tailed test

$* * \mathrm{p} \leq .05$, one-tailed test

$* * * \mathrm{p} \leq .01$, one-tailed test

$* * * * \mathrm{p} \leq .001$, one-tailed test

\section{Rule of Law / Bureaucratic Quality}

Table 5-8 displays the results for the rule of law / bureaucratic quality data set.

As indicated by Table 5-7, similar to the previous two data sets, collinearity is a problem because of the shared variables between the institutional index and the Polity 2 score. Although collinearity is serving to amplify the institutional index $\mathrm{Z}$ value, the model lends support for the institutional index and therefore the institutional threshold theory. It 
also provides considerable evidence for the education threshold and some evidence for the wealth threshold for democratic consolidation.

Table 5-7.

Correlation Matrix between the Level of Democratization and the Institutional Index

\begin{tabular}{c|cc}
\multicolumn{2}{c}{ Rule of Law / Bureaucratic Quality } & \\
& Level of Democratization & Index \\
\hline Level of Democratization & 1.0000 & \\
Index & 0.7842 & 1.0000
\end{tabular}

The rule of law / bureaucratic quality data set includes those component variables in the institutional index. That data is not available for all countries and all years of interest to the dissertation; therefore, sixty-two cases are tested for the years 1982 through 1997. As with the previous data sets, this data set offers empirical support for the institutional index and the institutional threshold theory indicating the necessity of political institutional consolidation as a forerunner to democratic consolidation. The literacy rate, or education threshold, receives great support from this model suggesting that democratic consolidation will occur with an increase in the literacy rate. The gross national product per capita, or wealth threshold for democratic consolidation, receives minimal support from this model since it is not statistically significant.

The colonial legacy variable, again contrary to political development literature, does not support the notion that a history as a British colony will lead to democratic consolidation. Also contrary to political development literature, the religion variable signifies that predominately Protestant states are not at an advantage in the process of democratic consolidation. Finally, the minorities at risk variable generates counterintuitive results denoting that the level of democratization will increase with the number of minority at risk groups located within a state. 
Table 5-8. Time Series Panel Regression for Level of Democratization Rule of Law / Bureaucratic Quality Full Model

\begin{tabular}{|l|l|l|l|}
\hline \multicolumn{1}{|c|}{ Variable } & \multicolumn{1}{|c|}{ Coefficient } & \multicolumn{1}{c|}{ Standard Error } & \multicolumn{1}{|c|}{ Z Value } \\
\hline Index & .1808886 & .0049052 & $36.88^{* * * *}$ \\
\hline GNP per capita & .0000528 & .0000594 & 0.89 \\
\hline Literacy & .0492494 & .0110981 & $4.44^{* * * *}$ \\
\hline Colonial Legacy & -.2309108 & .9391032 & -0.25 \\
\hline Religion & -1.0729 & 1.405036 & -0.76 \\
\hline Minorities at Risk & .0767105 & .1954396 & 0.39 \\
\hline Constant & -18.9331 & .9136207 & $-20.72^{* * * *}$ \\
\hline
\end{tabular}

$\mathrm{n}=62$ cases, 992 observations

Overall $\mathrm{R}^{2}=0.5934$

${ }^{*} \mathrm{p} \leq .10$, one-tailed test

$* * \mathrm{p} \leq .05$, one-tailed test

$* * * \mathrm{p} \leq .01$, one-tailed test

$* * * * \mathrm{p} \leq .001$, one-tailed test

The outputs for the component variables, including the rule of law and bureaucratic quality, are displayed in Table 5-9. The rule of law and bureaucratic quality component variables are both statistically significant, yet their significance levels are considerably weaker than the other component variable that compose the institutional index. The rule of law variable indicates that a strong court system that can implement laws and adjudicate disputes is important to democratic consolidation. The bureaucratic quality variable signifies the importance of a professionalized and meritorious bureaucracy, rather than a system based on political patronage, is also valuable to democratic consolidation.

Constraints on the chief executive and free and fair elections are once again the most significant component variables indicating their critical role in democratic 
consolidation. Party legitimacy is the most important intermediary institution to the process of democratic consolidation, while universal suffrage is the only variable in the model that does not return significant results.

Table 5-9. Time Series Panel Regression for Level of Democratization Rule of Law / Bureaucratic Quality Institution Variables

\begin{tabular}{|l|l|l|l|l|}
\hline \multicolumn{1}{|c|}{ Variable } & \multicolumn{1}{|c|}{ Coefficient } & \multicolumn{1}{|c|}{$\begin{array}{c}\text { Standard } \\
\text { Error }\end{array}$} & \multicolumn{1}{|c|}{ Z Value } & \multicolumn{1}{|c|}{ Overall R } \\
\hline $\begin{array}{l}\text { Openness of Exec. } \\
\text { Recruitment }\end{array}$ & .6607648 & .0436215 & $15.15^{* * * *}$ & 0.2030 \\
\hline $\begin{array}{l}\text { Constraints on the } \\
\text { Chief Executive }\end{array}$ & 1.293636 & .0267999 & $48.27^{* * * *}$ & 0.7544 \\
\hline $\begin{array}{l}\text { Legislative } \\
\text { Effectiveness }\end{array}$ & 1.182948 & .0576885 & $20.51^{* * * *}$ & 0.3993 \\
\hline $\begin{array}{l}\text { Legislative } \\
\text { Selection }\end{array}$ & .2291144 & .0425413 & $5.39^{* * * *}$ & 0.1964 \\
\hline $\begin{array}{l}\text { Constitutional } \\
\text { Checks }\end{array}$ & 2.175768 & .1128871 & $19.27^{* * * *}$ & 0.4538 \\
\hline $\begin{array}{l}\text { Rule of Law } \\
\text { Military }\end{array}$ & .2177811 & .0738905 & $2.95^{* * * *}$ & 0.1855 \\
\hline $\begin{array}{l}\text { Electoral System } \\
\text { Party Legitimacy }\end{array}$ & .7209997 & .0523514 & $13.77^{* * * *}$ & 0.3123 \\
\hline $\begin{array}{l}\text { Bureaucratic } \\
\text { Quality }\end{array}$ & .3741701 & .1072059 & $3.49^{* * * *}$ & 0.1870 \\
\hline $\begin{array}{l}\text { Press Freedom } \\
\text { Elections }\end{array}$ & .8028272 & .0492012 & $16.32^{* * * *}$ & 0.3636 \\
\hline $\begin{array}{l}\text { Universal Suffrage } \\
\text { Free and Fair }\end{array}$ & .1289847 & .183825 & 0.70 & 0.6262 \\
\hline
\end{tabular}

$\mathrm{n}=62$ cases, 992 observations

${ }^{*} \mathrm{p} \leq .10$, one-tailed test

$* * \mathrm{p} \leq .05$, one-tailed test

$* * * \mathrm{p} \leq .01$, one-tailed test

$* * * * \mathrm{p} \leq .001$, one-tailed test 


\section{Regime Change}

The last data set to addressed using the level of democratization as the dependent variable is Regime Change. As its name suggests, this data set includes a variable that analyses mild to dramatic regime changes. Since this data is not available for all states and years of interest, sixty-two states are analyzed covering the years 1974 through 1992. Table 5-10 displays the collinearity problems between the institutional index and the level of democratization indicator that has been troubling throughout this chapter.

Table 5-10.

Correlation Matrix between the Level of Democratization and the Institutional Index

\begin{tabular}{c|cc}
\multicolumn{2}{c}{ Regime Change } & \\
& Level of Democratization & Index \\
\hline Level of Democratization & 1.0000 & \\
Index & 0.7285 & 1.0000
\end{tabular}

As Table 5-11indicates, the three most important independent variables to this model, the institutional index, GNP per capita, and the literacy rate, all find supporting evidence from the Regime Change data set. The institutional index is strongly significant indicating the central role that political institutions play in democratic consolidation. The model also denotes, based upon the coefficients, that slight changes in the institutional index will lead to an increase in the level of democratization. The wealth threshold, measured by GNP per capita, is supported by this model which suggests that democratic consolidation is more likely to occur in wealthier states. Also, the literacy rate provides evidence for the education threshold implying that higher educated states are more likely to consolidate democracy.

Although hardly significant, this model returns the only results that correspond with political development literature suggesting that British colonies have an advantage in democratic consolidation. The religion variable, however, once again generates results 
inconsistent with political development literature as the variable suggests that predominately Protestant states are not any more likely than other types of religions to consolidate democracy. The minorities at risk variable returns somewhat concerning results as it implies that democratic consolidation will increase with an escalation in the number of minority at risk groups within a state.

The new variable to this data set, regime change, provides strongly significant results that may be troubling. This variable implies that democratic consolidation will occur when more dramatic regime changes take place. This is concerning if the revolutionary group is "anti-system” and fundamentally restructures the political system within the state. However, it is not troubling if the regime change dramatically alters the political system in a democratic fashion. 
Table 5-11. Time Series Panel Regression for Level of Democratization Regime Change Full Model

\begin{tabular}{|l|l|l|l|}
\hline \multicolumn{1}{|c|}{ Variable } & \multicolumn{1}{|c|}{ Coefficient } & \multicolumn{1}{c|}{ Standard Error } & \multicolumn{1}{|c|}{ Value } \\
\hline Index & .1374785 & .0040654 & $33.82^{* * * *}$ \\
\hline GNP per capita & .0002167 & .0001118 & $1.94^{* *}$ \\
\hline Literacy & .037451 & .0093478 & $4.01^{* * * *}$ \\
\hline Colonial Legacy & .0136184 & .7376168 & 0.02 \\
\hline Religion & -1.881476 & 1.086137 & $-1.73^{* *}$ \\
\hline Minorities at Risk & .1673189 & .1641686 & 1.02 \\
\hline Regime Change & .5918719 & .0720043 & $8.22^{* * * *}$ \\
\hline Constant & -13.9179 & .6561841 & $-21.21^{* * * *}$ \\
\hline
\end{tabular}

$\mathrm{n}=62$ cases, 1178 observations

Overall $\mathrm{R}^{2}=0.5476$

$* \mathrm{p} \leq .10$, one-tailed test

$* * \mathrm{p} \leq .05$, one-tailed test

$* * * \mathrm{p} \leq .01$, one-tailed test

$* * * * \mathrm{p} \leq .001$, one-tailed test

The inclusion of regime change into the models for the component variables of the institutional index does not alter the performance of the variables. Displayed in Table 5-12, as with the previous models, constraints on the chief executive produces the highest significance level with free and fair elections and party legitimacy placing second and third. With the exception of universal suffrage, all variables are statistically significant at .001 indicating that each of these variables has a critical function in the process of democratic consolidation. 
Table 5-12. Time Series Panel Regression for Level of Democratization

Regime Change Institution Variables

\begin{tabular}{|l|l|l|l|l|}
\hline \multicolumn{1}{|c|}{ Variable } & \multicolumn{1}{|c|}{ Coefficient } & \multicolumn{1}{|c|}{$\begin{array}{c}\text { Standard } \\
\text { Error }\end{array}$} & \multicolumn{1}{|c|}{$\mathbf{Z}$ Value } & Overall $\mathbf{R}^{2}$ \\
\hline $\begin{array}{l}\text { Openness of Exec. } \\
\text { Recruitment }\end{array}$ & .4229582 & .0287297 & $14.72^{* * * *}$ & 0.2172 \\
\hline $\begin{array}{l}\text { Constraints on the } \\
\text { Chief Executive }\end{array}$ & 1.201958 & .022218 & $54.10^{* * * *}$ & 0.7539 \\
\hline $\begin{array}{l}\text { Legislative } \\
\text { Effectiveness }\end{array}$ & .8230794 & .038852 & $21.19^{* * * *}$ & 0.3778 \\
\hline $\begin{array}{l}\text { Legislative } \\
\text { Selection }\end{array}$ & .2398799 & .024527 & $9.78^{* * * * *}$ & 0.2085 \\
\hline $\begin{array}{l}\text { Constitutional } \\
\text { Checks }\end{array}$ & 1.827744 & .1116825 & $16.37^{* * * *}$ & 0.4219 \\
\hline $\begin{array}{l}\text { Military } \\
\text { Electoral System }\end{array}$ & .5731214 & .03829567 & $14.42^{* * * * *}$ & 0.2198 \\
\hline Party Legitimacy & .8310133 & .0324324 & $25.62^{* * * * *}$ & 0.5162 \\
\hline Press Freedom & .8471333 & .0486407 & $17.42^{* * * *}$ & 0.3564 \\
\hline $\begin{array}{l}\text { Free and Fair } \\
\text { Elections }\end{array}$ & .8362389 & .0239199 & $34.96^{* * * *}$ & 0.6223 \\
\hline Universal Suffrage & .063757 & .0909597 & 0.70 & 0.1852 \\
\hline
\end{tabular}

$\mathrm{n}=62$ cases, 1178 observations

${ }^{*} \mathrm{p} \leq .10$, one-tailed test

$* * \mathrm{p} \leq .05$, one-tailed test

$* * * \mathrm{p} \leq .01$, one-tailed test

$* * * * \mathrm{p} \leq .001$, one-tailed test

\section{Alternative Models}

Because of the collinearity that exists between the level of democratization, the dependent variable, and the institutional index, it is necessary to use alternative models to determine the accuracy of the initial results. Two alternative dependent variables, the Freedom House Democracy Indicator and the change in the level of democratization, are employed. 
The Freedom House data alternative model is tested using a time series panel regression with a three year moving average. This means that the institutional index is lagged for three years and an average of those three years is then regressed, using the time series panel technique, on the Freedom House data.

Table 5-13 provides the results, using the Freedom House Democracy Indicator as the dependent variable, of the full models for the four different data sets. With small variations, using the Freedom House Democracy Indicator as the dependent variable, the results are duplicates of the level of democratization findings. Across all four data sets, the Freedom House data results reduce the statistical significance of the institutional index, although it is still strongly significant, while increase the significance levels of the other independent variables such as the gross national product per capita, the literacy rate, colonial legacy, religion, and minorities at risk. This suggests that, after solving the collinearity problem, the institutional index is still overwhelmingly significant in the process of democratic consolidation, yet the other independent variables also have a role to play in democratic consolidation. This was overlooked in the initial results that had problems with collinearity. 
Table $5-13^{15}$. Time Series Panel Regression (with a 3 year moving average) for the Freedom House Democracy Indicator (Full Models)

\begin{tabular}{|c|c|c|c|c|}
\hline Variables & $\begin{array}{c}1974 \text { through } \\
2000\end{array}$ & $\begin{array}{c}\text { Entered } \\
\text { System Late }\end{array}$ & $\begin{array}{l}\text { Rule of Law / } \\
\text { Bur. Quality }\end{array}$ & $\begin{array}{l}\text { Regime } \\
\text { Change }\end{array}$ \\
\hline Index & $.056 * * * *$ & $.035 * * * *$ & $.055 * * * *$ & $.034 * * * *$ \\
\hline GNP per capita & $.001 *$ & $.001 * *$ & .001 & $.001 * * *$ \\
\hline Literacy & $.011 * * *$ & $.017^{* * *}$ & $.015 * * *$ & $.028 * * * *$ \\
\hline $\begin{array}{l}\text { Colonial } \\
\text { Legacy }\end{array}$ & $-.748 * *$ & $-1.621 * * * *$ & $-1.139 * * *$ & -2.962 \\
\hline Religion & $1.051 * *$ & $3.086 * * * *$ & $1.529 * *$ & .146 \\
\hline $\begin{array}{l}\text { Minorities at } \\
\text { Risk }\end{array}$ & $-.148 * *$ & $-0.201^{* *}$ & $-.229 * * *$ & -.110 \\
\hline Regime Change & & & & $.103 * *$ \\
\hline Constant & $1.720 * * * *$ & $2.911 * * * *$ & $1.418 * * *$ & $1.899 * * * *$ \\
\hline Overall $\mathrm{R}^{2}$ & .497 & .503 & .510 & .427 \\
\hline $\mathrm{n}=$ & $\begin{array}{l}70 \text { cases } \\
1680 \text { observations }\end{array}$ & $\begin{array}{l}87 \text { cases } \\
609 \text { observations }\end{array}$ & $\begin{array}{l}62 \text { cases } \\
806 \text { observations }\end{array}$ & $\begin{array}{l}62 \text { cases } \\
992 \text { observations }\end{array}$ \\
\hline
\end{tabular}

${ }^{*} \mathrm{p} \leq .10$, one-tailed test

$* * \mathrm{p} \leq .05$, one-tailed test

$* * * \mathrm{p} \leq .01$, one-tailed test

$* * * * \mathrm{p} \leq .001$, one-tailed test

Table 5-14 provides the results, using the Freedom House Democracy Indicator as the dependent variable, of the component variables of the institutional index for the four different data sets. Once again, the findings are duplicates of the initial results. The Freedom House data does reduce the significance levels of the component variables; however, removing the collinearity from the models still produce overwhelming support for strengthening the component variables of the institutional index as a means to consolidate democracy.

\footnotetext{
15 The results for each data set, using the Freedom House Democracy Indicator as the dependent variable, can be found in Appendix 4.
} 
Table 5-14. Time Series Panel Regression (with a 3 year moving average) for the Freedom House Democracy Indicator (Institution Models)

\begin{tabular}{|c|c|c|c|c|}
\hline Variables & $\begin{array}{c}1974 \text { through } \\
2000\end{array}$ & $\begin{array}{c}\text { Entered } \\
\text { System Late }\end{array}$ & $\begin{array}{l}\text { Rule of Law / } \\
\text { Bur. Quality }\end{array}$ & $\begin{array}{l}\text { Regime } \\
\text { Change }\end{array}$ \\
\hline $\begin{array}{l}\text { Openness of } \\
\text { Exec. Rect. }\end{array}$ & $.161 * * * *$ & $.096 * * * *$ & $.162 * * * *$ & $.078 * * * *$ \\
\hline $\begin{array}{l}\text { Constraints on } \\
\text { Chief Exec. }\end{array}$ & $.379 * * * *$ & $.230 * * * *$ & $.360 * * * *$ & $.255 * * * *$ \\
\hline $\begin{array}{l}\text { Legislative } \\
\text { Effectiveness }\end{array}$ & $.430 * * * *$ & $.239 * * * *$ & $.452 * * * *$ & $.284 * * * *$ \\
\hline $\begin{array}{l}\text { Legislative } \\
\text { Selection }\end{array}$ & $.145 * * * *$ & $.096 * * * *$ & $.141 * * * *$ & $.090 * * * *$ \\
\hline $\begin{array}{l}\text { Constitutional } \\
\text { Checks }\end{array}$ & $.634 * * * *$ & $.178 * * *$ & $.517 * * * *$ & $.147 * *$ \\
\hline Rule of Law & & & $.084 * *$ & \\
\hline Military & $.203 * * * *$ & $.211 * * * *$ & $.227 * * * *$ & $.132 * * * *$ \\
\hline $\begin{array}{l}\text { Electoral } \\
\text { System }\end{array}$ & $.182 * * * *$ & $.044 *$ & $.154 * * * *$ & $.112 * * * *$ \\
\hline $\begin{array}{l}\text { Party } \\
\text { Legitimacy }\end{array}$ & $.315 * * * *$ & $.060 * * *$ & $.301 * * * *$ & $.299 * * * *$ \\
\hline $\begin{array}{l}\text { Bureaucratic } \\
\text { Quality }\end{array}$ & & & $.117 * *$ & \\
\hline Press Freedom & $.383 * * * *$ & $.041 * *$ & $.313 * * * *$ & $.346 * * * *$ \\
\hline $\begin{array}{l}\text { Free and Fair } \\
\text { Elections }\end{array}$ & $.234 * * * *$ & $.103 * * * *$ & $.192 * * * *$ & $.140 * * * *$ \\
\hline $\begin{array}{l}\text { Universal } \\
\text { Suffrage }\end{array}$ & $.229 * * * *$ & .099 & $.429 * * * *$ & -.044 \\
\hline $\mathrm{n}=$ & $\begin{array}{l}70 \text { cases } \\
1680 \text { observations }\end{array}$ & $\begin{array}{l}87 \text { cases } \\
609 \text { observations }\end{array}$ & $\begin{array}{l}62 \text { cases } \\
806 \text { observations }\end{array}$ & $\begin{array}{l}62 \text { cases } \\
992 \text { observations }\end{array}$ \\
\hline
\end{tabular}

$* \mathrm{p} \leq .10$, one-tailed test

$* * \mathrm{p} \leq .05$, one-tailed test

$* * * \mathrm{p} \leq .01$, one-tailed test

$* * * * \mathrm{p} \leq .001$, one-tailed test

The second alternative model utilizes the change in the level of democratization as the dependent variable. Although it is more difficult to produce statistically significant results when using change as the dependent variable, Table 5-15 indicates that the institutional index is statistically significant in two of the four models. Overall, these models do not perform as well as the level of democratization or Freedom House models; 
however, it can be concluded that the institutional index is a necessary component of democratic consolidation.

Table $5-15^{16}$.

Time Series Panel Regression for the Change in the Level of Democratization (Full Models)

\begin{tabular}{|l|l|l|l|l|}
\hline \multicolumn{1}{|c|}{ Variables } & \multicolumn{1}{|c|}{$\begin{array}{c}\mathbf{1 9 7 4} \text { through } \\
\mathbf{2 0 0 0}\end{array}$} & $\begin{array}{c}\text { Entered } \\
\text { System Late }\end{array}$ & $\begin{array}{c}\text { Rule of Law / } \\
\text { Bur. Quality }\end{array}$ & \multicolumn{1}{c|}{$\begin{array}{c}\text { Regime } \\
\text { Change }\end{array}$} \\
\hline Index & $.004^{* *}$ & .004 & .003 & $.007^{* * *}$ \\
\hline GNP per capita & -.001 & .001 & -.001 & -.001 \\
\hline Literacy & .001 & $-.009^{* * *}$ & .003 & .001 \\
\hline $\begin{array}{l}\text { Colonial } \\
\text { Legacy }\end{array}$ & $-.349^{* * *}$ & -.169 & $-.354^{* *}$ & $-.343^{* *}$ \\
\hline Religion & .100 & .267 & .222 & .192 \\
\hline $\begin{array}{l}\text { Minorities at } \\
\text { Risk }\end{array}$ & .009 & .038 & -.035 & -.015 \\
\hline Regime Change & & & & $.383^{* * * *}$ \\
\hline Constant & .032 & $.506^{*}$ & .182 & -.114 \\
\hline Overall $\mathrm{R}^{2}$ & .008 & .009 & .011 & .047 \\
\hline $\mathrm{n}=$ & $\begin{array}{l}.00 \text { cases } \\
1890 \text { observations }\end{array}$ & $\begin{array}{l}87 \text { cases } \\
870 \text { observations }\end{array}$ & $\begin{array}{l}62 \text { cases } \\
992 \text { observations }\end{array}$ & $\begin{array}{l}62 \text { cases } \\
1178 \text { observations }\end{array}$ \\
\hline
\end{tabular}

${ }^{*} \mathrm{p} \leq .10$, one-tailed test

${ }^{* *} \mathrm{p} \leq .05$, one-tailed test

$* * * \mathrm{p} \leq .01$, one-tailed test

$* * * * \mathrm{p} \leq .001$, one-tailed test

The findings of the component variables of the institutional index are found in

Table 5-16. Several variables return results worth noting. Across all four models, the openness of executive recruitment and the constraints placed on the chief executive are both strongly significant. This indicates that granting the politically active population the

\footnotetext{
${ }^{16}$ The results for each data set, using change in the level of democratization as the dependent variable, can be found in Appendix 5.
} 
opportunity to compete for the chief executive position through an electoral process will lead to an increase in the level of democratization. Also, this suggests that placing constraints on the chief executive through accountability organizations will also lead to a democratic increase. The role of the military is statistically significant across all four data sets signifying that as the civilian government subordinates control of the military, democracy will also increase. The electoral system variable generates results demonstrating that a parliamentary system will more likely produce democratic consolidation than either a presidential or hybrid type of electoral system. Finally, the free and fair elections variable is significant specifying the need for competitive elections in the process of democratic consolidation. There is also some evidence to suggest that a free press and the inclusion of opposition political parties are necessary to provide for democratic consolidation. 
Table 5-16.

Time Series Panel Regression for the Change in the Level of Democratization

\begin{tabular}{|c|c|c|c|c|}
\hline \multicolumn{5}{|c|}{ (Institution Models) } \\
\hline Variables & $\begin{array}{c}1974 \text { through } \\
2000\end{array}$ & $\begin{array}{c}\text { Entered } \\
\text { System Late }\end{array}$ & $\begin{array}{c}\text { Rule of Law / } \\
\text { Bur. Quality }\end{array}$ & $\begin{array}{l}\text { Regime } \\
\text { Change }\end{array}$ \\
\hline $\begin{array}{l}\text { Openness of } \\
\text { Exec. Rect. }\end{array}$ & $.024 * * *$ & $.062 * * * *$ & $.039 * * *$ & $.022 * *$ \\
\hline $\begin{array}{l}\text { Constraints on } \\
\text { Chief Exec. }\end{array}$ & $.066^{* * * * *}$ & $.075 * * * *$ & $.069 * * * *$ & $.089 * * * *$ \\
\hline $\begin{array}{l}\text { Legislative } \\
\text { Effectiveness }\end{array}$ & $.027 *$ & .022 & .021 & $.040^{* *}$ \\
\hline $\begin{array}{l}\text { Legislative } \\
\text { Selection }\end{array}$ & .006 & -.014 & -.002 & $.020 *$ \\
\hline $\begin{array}{l}\text { Constitutional } \\
\text { Checks }\end{array}$ & $-.198 * * * *$ & $-.223 * * * *$ & $-.257 * * * *$ & $-.293 * * * *$ \\
\hline Rule of Law & & & -.035 & \\
\hline Military & $.043 * * * *$ & $.061 * * *$ & $.040 * *$ & $.060 * * * *$ \\
\hline $\begin{array}{l}\text { Electoral } \\
\text { System }\end{array}$ & $-.059 * * * *$ & $-.059 * * *$ & $-.043 * *$ & $-.073 * * * *$ \\
\hline $\begin{array}{l}\text { Party } \\
\text { Legitimacy }\end{array}$ & $.035 * * *$ & .011 & $.031 * *$ & $.057 * * * *$ \\
\hline $\begin{array}{l}\text { Bureaucratic } \\
\text { Quality }\end{array}$ & & & -.004 & \\
\hline Press Freedom & -.006 & $-.049 * *$ & $-.032 * *$ & .016 \\
\hline $\begin{array}{l}\text { Free and Fair } \\
\text { Elections }\end{array}$ & $.035 * * * *$ & $.035 * * *$ & $.032 * * *$ & $.061 * * * *$ \\
\hline $\begin{array}{l}\text { Universal } \\
\text { Suffrage }\end{array}$ & .008 & -.045 & -.009 & .024 \\
\hline $\mathrm{n}=$ & $\begin{array}{l}70 \text { cases } \\
1890 \text { observations }\end{array}$ & $\begin{array}{l}87 \text { cases } \\
870 \text { observations }\end{array}$ & $\begin{array}{l}62 \text { cases } \\
992 \text { observations }\end{array}$ & $\begin{array}{l}62 \text { cases } \\
1178 \text { observations }\end{array}$ \\
\hline
\end{tabular}

${ }^{*} \mathrm{p} \leq .10$, one-tailed test

$* * \mathrm{p} \leq .05$, one-tailed test

$* * * \mathrm{p} \leq .01$, one-tailed test

$* * * * \mathrm{p} \leq .001$, one-tailed test 


\section{Conclusions}

The purpose of this chapter has been to test the first stage of analysis by examining the impact that political institutions have on democratic consolidation. Because of the need to use four different data sets, due to data limitations, it is important to draw conclusions across the entire chapter. Overall, this chapter provides strong empirical evidence regarding the need to strengthen political institutions as a prerequisite to democratic consolidation. The chapter also lends support for the wealth and education thresholds.

Using the level of democratization as the dependent variable, the most important independent variable to this dissertation, the institutional index, receives strong empirical support. The institutional index is the means through which the institutional threshold theory is tested on the level of democratization as the dependent variable. As can be seen in Figure 5-1, the institutional index is highly significant across the four different data sets. Nonetheless, the strong empirical support implies that following the institutional threshold theory, meaning that a majority of a states political institutions have been strengthened, will reduce the amount of time that states spend in the democratizing process, thereby eliminating the dangerous and disruptive behavior that is associated with democratization. This also prevent states from becoming entrenched anocracies because they have focused on regime reforms and have political institutions in place that serve to regulate behavior and accommodate political opposition. 
Figure 5-1. Performance of the Institutional Index ${ }^{17}$

Level of Democratization

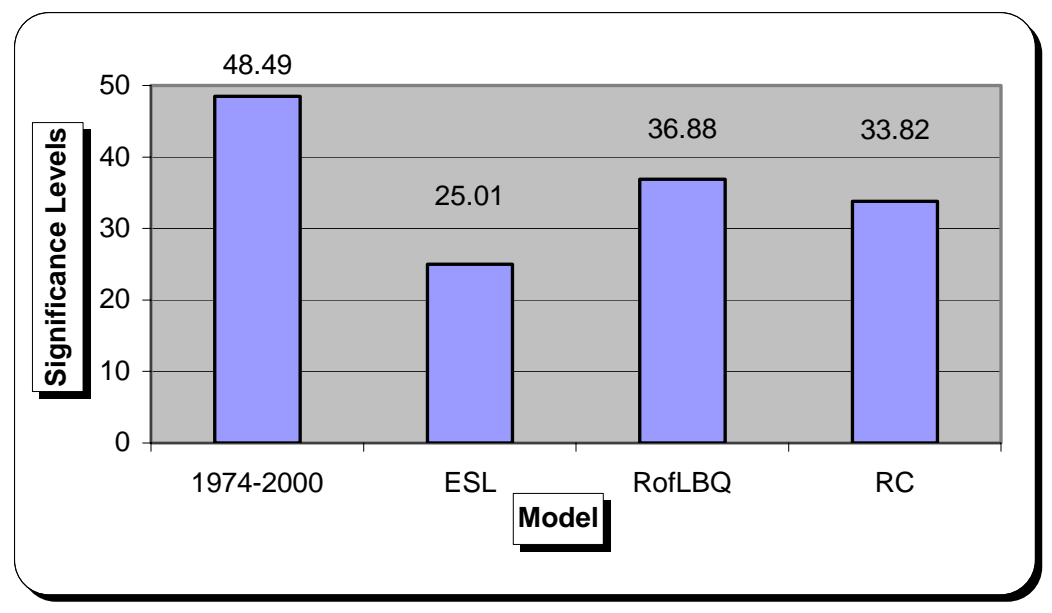

Through the use of its control variables, this chapter has tested the wellestablished ideas that wealth and education thresholds serve as prerequisites for democratic consolidation. Strong support was found across the four data sets for the education threshold implying that higher levels of education are necessary for democratic consolidation because of the participatory aspects involved in a democracy. Weaker evidence was attained across the data sets for the wealth threshold. However, it can be concluded that affluence will allow for democratic consolidation to take place more rapidly.

Contrary to the political development literature, no support was found to suggest that states are advantaged in democratic consolidation if they have a history of being a British colony or are predominately Protestant in religion. The final control variable, minorities at risk, returned insignificant but counter-intuitive results indicating that democratic consolidation will occur with an increase in minorities at risk groups located

\footnotetext{
${ }^{17}$ The conclusion section of each of the quantitative chapters, Chapters Five, Six, and Seven, include figures which detail the performance of the institutional index, the level of democratization, and the performance of the component variables of the institutional index based upon their significance levels. The variables are statistically significant at the .05 level of 1.65. Anything above 1.65 on the bar charts demonstrates statistical significance.
} 
within the state. An explanation for these results may be that minorities at risk groups work within the political system rather than resorting to violent tactics.

As Figure 5-2 indicates, the component variables of the institutional index perform with relative equivalency across all data sets. The chart also displays the importance of all thirteen component variables of the institutional index in the process of democratic consolidation because all variables returned significant results. Based upon these results, an order of importance can be assigned to these variables.

Of the eight governmental institutions, constraints on the chief executive was the best performer indicating the critical importance in constraining the chief executive to allow for democratic consolidation. The remaining institutions are ordered based upon their decreasing level of importance to democratic consolidation - legislative effectiveness, constitutional checks, openness of executive recruitment, the electoral system, the role of the military, legislative selection, and the rule of law. Therefore, according to these results, the rule of law is the least critical governmental institution in the process of democratic consolidation.

Across all four data sets, free and fair elections is the most important intermediary institution to democratic consolidation. Party legitimacy is a close second, followed by press freedom and bureaucratic quality. Based upon its insignificant results, universal suffrage is the least essential intermediary institution in the process of democratic consolidation. 
Figure 5-2. Performance of the Component Variables of the Institutional Index Level of Democratization

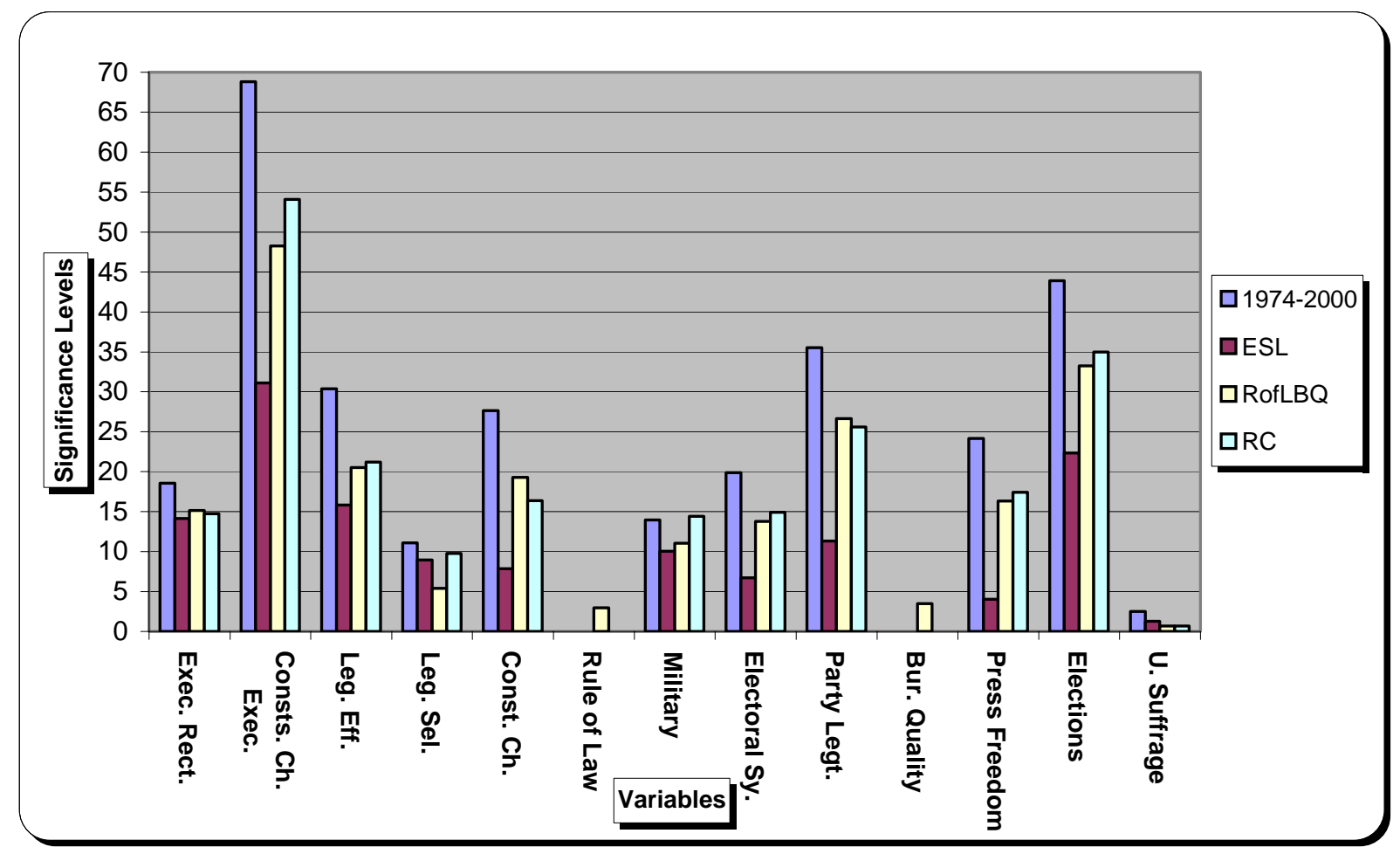

Freedom House

The inclusion of two alternative dependent variables allows for more confidence to be placed on the initial findings, regardless of the collinearity problem in the data. The summary information for the Freedom House data can be found in Figures 5-3 and 5-4. This alternative dependent variable confirms the results found initially using the level of democratization as the dependent variable. 
Figure 5-3. Performance of the Institutional Index Freedom House Democracy Indicator

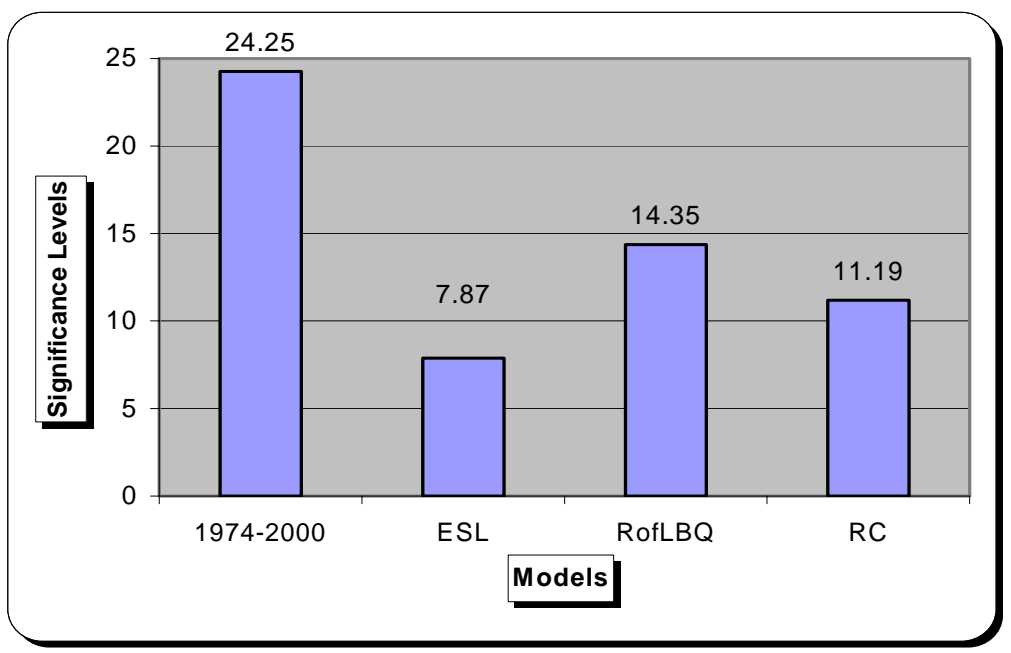

Figure 5-4. Performance of the Component Variables of the Institutional Index Freedom House Democracy Indicator

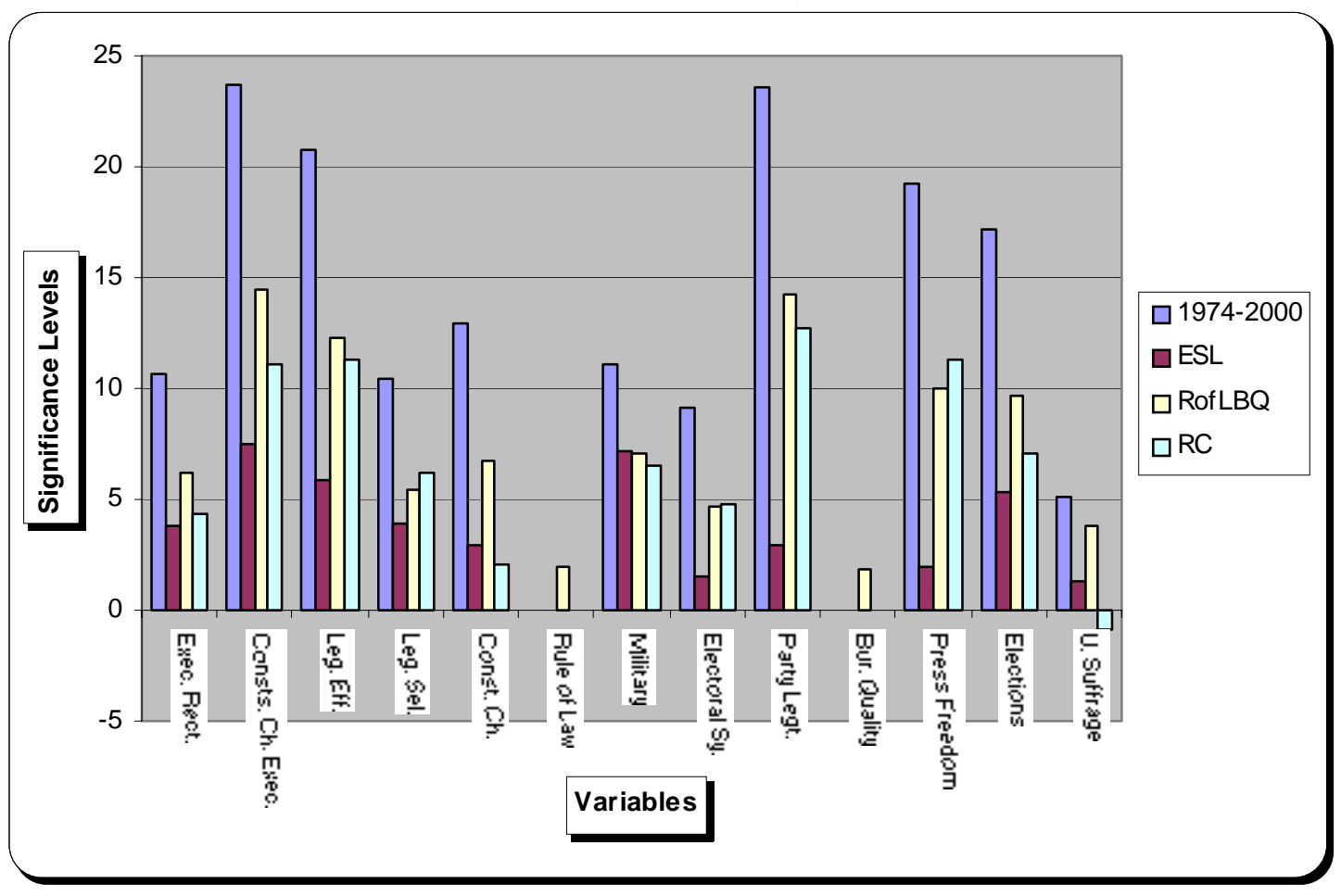




\section{Change in the Level of Democratization}

Figure 5-5 and 5-6 present the summary information for the institutional index and the component variables of the institutional index using the change in the level of democratization as the dependent variable. As Figure 5-5 displays, the institutional index is significant in two of the four data sets indicating that strengthening political institutions will lead to an increase in the level of democratization.

Figure 5-5. Performance of the Institutional Index

Change in the Level of Democratization

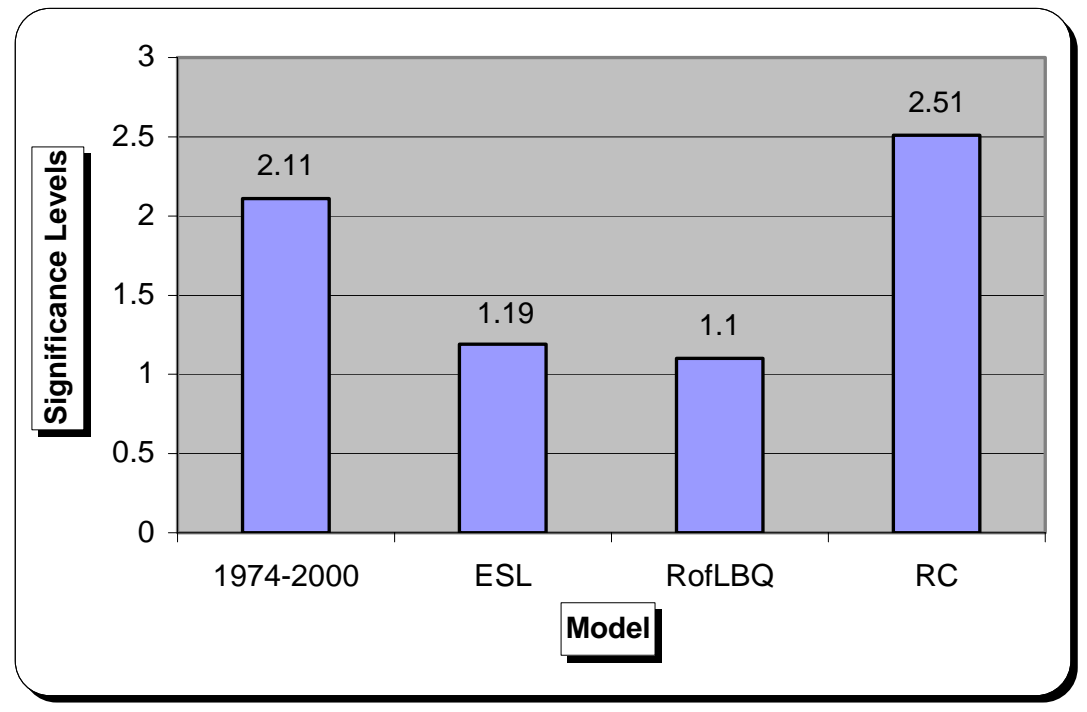

Figure 5-6 portrays the component variable information. Compared to the results discussed earlier in this chapter, the variables perform somewhat differently. However, the two most significant variables are the constraints placed on the chief executive and free and fair elections, which is similar to the earlier models. 
Figure 5-6. Performance of the Component Variables of the Institutional Index Change in the Level of Democratization

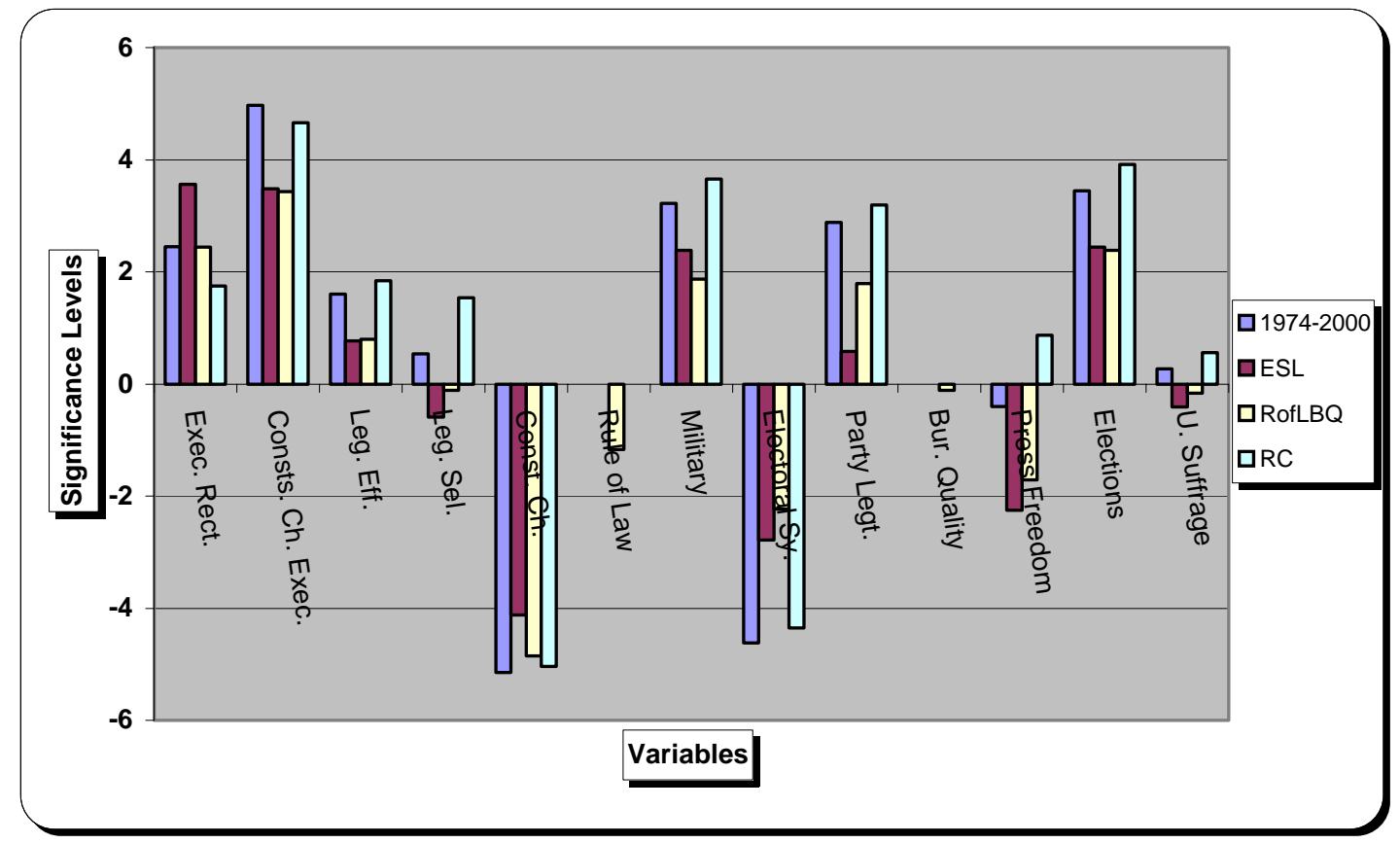

Overall, this chapter tested two hypotheses:

H1. States that are making the transition to democracy while establishing strong political institutions, as evidenced by a higher institutional index score, are more

Strong evidence was gathered to support Hypothesis 1. States that focus on regime reforms, primarily strengthening their political institutions, will consolidate democracy.

H3. Governmental institutions have a greater positive influence on democratic consolidation than intermediary institutions.

Hypothesis 3 suggests that governmental institutions are more important to democratic consolidation than intermediary institutions. However, this chapter did not produce any supporting evidence for this hypothesis. In fact, evidence is gathered to demonstrate that both governmental and intermediary institutions are vital to democratic consolidation. 
This chapter has served to test the first stage of analysis between political institutions and the level of democratization. The next two quantitative chapters will test the second stage of analysis by examining the relationship that exists between political institutions, the level of democratization, and their mutual influence on conflict. 


\section{Chapter 6 - Militarized Interstate Disputes \\ Introduction}

This quantitative chapter tests the second stage of analysis through an examination of political institutions, a state's level of democratization, and their collective effect on conflict. The dependent variable for chapter six is the militarized interstate dispute which "refers to historical cases in which the threat, display, or use of military force by one member state is explicitly directed towards the government, official representatives, official forces, property, or territory of another state” (Jones, Bremer, and Singer 1996 168). This chapter remains consistent with previous research on the democratic peace and democratization and war since it tests the theory and hypotheses on external conflict. A time series panel logit using a combination of random and fixed effects commands is the quantitative method employed in the chapter. Once again, because of data limitations, four data sets are necessary to evaluate the institutional threshold theory, answer the research questions, and test the related hypotheses. Two hypotheses are tested in this quantitative chapter:

H2. States that are making the transition to democracy while establishing strong political institutions, as evidenced by a higher institutional index score, are less likely to be involved in armed conflict.

H3. Governmental institutions have a greater positive influence on democratic consolidation than intermediary institutions.

\section{Results}

$1974-2000$

Similar to the previous chapter, this chapter tests two models per data set - the full model and the institution variables model. The full model serves to test the 
institutional index, whereas in the institution variables model, the component variables are used instead of the institutional index. The first data set, 1974 through 2000, analyses the entire time frame of interest, but does so for a reduced number of countries. As Table 6-1 demonstrates, overall, this model performs well with a high Wald chi ${ }^{2}$ score; however, the majority of the explanatory variables of this model are not the variables of importance to the dissertation.

The level of democratization indicator, the Polity 2 score, appears to be counterintuitive because there is a weak positive relationship which suggests that a state's involvement in militarized interstate disputes will increase as the level of democratization increases. However, this actually lends support for Mansfield and Snyder's contradictory premise to the democratic peace which suggests that democratizing states are more war prone than any other type of regime. Like the Polity 2 score, the institutional index is not significant. However, it does imply that a states participation in militarized interstate disputes will increase as political institutions become less viable. This lends weak support for the institutional threshold theory.

This model is primarily explained by the conflict control variables. Minorities at risk, state capabilities, and contiguity are strongly significant. The minorities at risk variables indicates that a states involvement in conflict will increase as more minority groups are declared to be "at risk" within the state. The state capabilities variable signifies that as state capabilities, acting as an indicator of state's power, increase the state's involvement in militarized interstate disputes will also increase. This suggests that states are wielding their power in the international system in an attempt to amplify that power, through conflict if necessary. The contiguity variable remains consistent with 
conflict literature demonstrating that a states involvement in MIDs will be more likely for those states that have numerous contiguous relationships. The only control variable that is not significant, the alliance variable, implies that an increase in alliance membership will lead to more involvement in militarized interstate disputes.

Table 6-1. Time Series Panel Logit for Militarized Interstate Disputes 1974 through 2000 Full Model ${ }^{18}$

\begin{tabular}{|l|l|l|l|}
\hline \multicolumn{1}{|c|}{ Variable } & \multicolumn{1}{|c|}{ Coefficient } & \multicolumn{1}{c|}{ Standard Error } & \multicolumn{1}{c|}{ Z Value } \\
\hline Polity 2 & .0211707 & .0179865 & 1.18 \\
\hline Index & -.0024335 & .0038023 & -0.64 \\
\hline Minorities at Risk & .25591 & .0475515 & $5.38^{* * * *}$ \\
\hline State Capabilities & 78.26133 & 28.95366 & $2.70^{* * *}$ \\
\hline Contiguity & .1620006 & .038797 & $4.18^{* * * *}$ \\
\hline Alliances & .0115638 & .0083105 & 1.39 \\
\hline Constant & -2.748276 & .3944428 & $-6.97^{* * * *}$ \\
\hline
\end{tabular}

$\mathrm{n}=70$ cases, 1890 observations

Wald $\mathrm{chi}^{2}=127.44$

${ }^{*} \mathrm{p} \leq .10$, one-tailed test

$* * \mathrm{p} \leq .05$, one-tailed test

$* * * \mathrm{p} \leq .01$, one-tailed test

$* * * * \mathrm{p} \leq .001$, one-tailed test

The logit model allows for the generation of probabilities which indicates whether the model has accurately predicted the outcome of the dependent variable, which in this case is the presence of a militarized interstate dispute. Predicted probabilities greater than .5 assume that a MID is present, whereas probabilities less than .499 suggest the

\footnotetext{
${ }^{18}$ To improve the model, a combination of random and fixed effects regression is used. The following countries are used as dichotomous variables - Brazil, Mexico, Nicaragua, Niger, South Korea, and Thailand. The country dummy variables are included in the full model and the models for the institutional variables.
} 
absence of a militarized interstate dispute. As Table 6-2 displays, this particular model predicted $76 \%$ of the total observations in the data set. The model predicted $90 \%$ of the no conflict situations correctly, whereas only $40 \%$ of the conflict situations were predicted accurately. The model does not predict the instances of conflict as well as the instances of peace, which is partly the fault of model misspecification, but is also an artifact of logit analysis since the models always predict the "0" situations more accurately.

Table 6-2. Predicted Outcomes for Militarized Interstate Disputes

\begin{tabular}{l|lll}
\multicolumn{4}{c}{1974 through 2000} \\
& $\mathbf{0}$ & $\mathbf{1}$ & Total \\
\hline $\mathbf{0}$ & 1205 & 129 & 1334 \\
$\mathbf{1}$ & 334 & 222 & 556 \\
Total & 1539 & 351 & 1890
\end{tabular}

As Table 6-3 illustrates, more than half of the component variables of the institutional index return evidence supporting the institutional threshold theory and the role that political institutions play in democratic consolidation and the prevention of militarized interstate disputes. Two variables are used to measure the role of the legislative and executive branches. All four component variables support the necessity of the institutional threshold. The openness of executive recruitment variable indicates that those regimes that have an open system of recruitment for the chief executive will be less likely to be involved in a militarized interstate dispute. Although not significant, according to the constraint on the chief executive variables, states that do not place formal constraints on the decision-making power of the chief executive are more likely to be involved in a MID. Those states that do not have an effective legislature, meaning the 
branch is autonomous and has the ability to create and implement laws, are more likely to be involved in external conflict. States that possess a non-existent or non-elected legislature are also more likely to be involved in a militarized interstate dispute.

If the state has a military government, in which there is direct military control, it is more likely to be involved in a militarized interstate dispute. Contrary to democratization literature, states that have a parliamentary type of electoral system, rather than a presidential or hybrid system, are more likely to be involved in external conflict. The democratization literature suggests that parliamentary governments are more inclusive, more likely to consolidate democracy, and produce long-term, stable democratic regimes. However, this model suggests that presidential systems are more favorable to democratic consolidation. The final variable to return results consistent with the institutional threshold theory is press freedom. Although the variable is not significant, it suggests that those states which lack a free press, meaning that the press is not capable of operating as an arena of political competition, are more likely to be involved in militarized interstate disputes. The coefficients of the significant variables suggest that a small decrease in their institutional performance will lead to an increase in militarized interstate disputes.

The constitutional checks variable, party legitimacy, free and fair elections, and universal suffrage return results inconsistent with hypothesized effects. As indicated by the Wald chi ${ }^{2}$ scores, these models perform relatively well. However, the explanatory variables in the model are the conflict control variables, opposed to the component variables of the institutional index and the level of democratization indicator. 
Table 6-3. Time Series Panel Logit for Militarized Interstate Disputes 1974 through 2000 Institution Variables

\begin{tabular}{|l|l|l|l|l|}
\hline \multicolumn{1}{|c|}{ Variable } & \multicolumn{1}{|c|}{ Coefficient } & \multicolumn{1}{|c|}{$\begin{array}{c}\text { Standard } \\
\text { Error }\end{array}$} & \multicolumn{1}{|c|}{ Z Value } & Wald chi $^{2}$ \\
\hline $\begin{array}{l}\text { Openness of } \\
\text { Exec. Rect. }\end{array}$ & -.0312512 & .0146628 & $-2.13^{* * *}$ & 131.08 \\
\hline $\begin{array}{l}\text { Constraints on the } \\
\text { Chief Executive }\end{array}$ & -.0256285 & .0331857 & -0.77 & 127.92 \\
\hline $\begin{array}{l}\text { Legislative } \\
\text { Effectiveness }\end{array}$ & -.0457815 & .0263586 & $-1.74^{* * *}$ & 131.15 \\
\hline $\begin{array}{l}\text { Legislative } \\
\text { Selection }\end{array}$ & -.009786 & .0142873 & -0.68 & 127.89 \\
\hline $\begin{array}{l}\text { Constitutional } \\
\text { Checks }\end{array}$ & .0831816 & .062963 & $1.32^{*}$ & 126.06 \\
\hline $\begin{array}{l}\text { Military } \\
\text { Electoral System }\end{array}$ & -.0300575 & .0181408 & $-1.66^{* *}$ & 131.85 \\
\hline Party Legitimacy & .04646 & .0201961 & $1.88^{* *}$ & 129.02 \\
\hline Press Freedom & -.0143266 & .0207328 & $2.24^{* *}$ & 125.34 \\
\hline $\begin{array}{l}\text { Free and Fair } \\
\text { Elections }\end{array}$ & .0018266 & .0204239 & 0.09 & 126.07 \\
\hline $\begin{array}{l}\text { Universal } \\
\text { Suffrage }\end{array}$ & .0042423 & .0417613 & 0.10 & 126.17 \\
\hline
\end{tabular}

$\mathrm{n}=70$ cases, 1890 observations

${ }^{*} \mathrm{p} \leq .10$, one-tailed test

$* * \mathrm{p} \leq .05$, one-tailed test

$* * * \mathrm{p} \leq .01$, one-tailed test

$* * * * \mathrm{p} \leq .001$, one-tailed test

\section{Entered System Late}

Entered System Late is the next data set to be discussed. This data set accounts for a smaller time frame, 1991 through 2000. However, all of the countries of interest to this dissertation are included in the data set. As Table 6-4 indicates, the model does not return considerable evidence to support the institutional threshold theory. The model does not perform well overall, which is indicated by the goodness of fit test, the low Wald chi $^{2}$ score. 
The Polity 2 score, or the level of democratization indicator returns results consistent with conventional wisdom suggesting that an increase in militarized interstate disputes will occur with a decrease in the level of democratization. This does not, however, produce evidence for Mansfield and Snyder's contradictory claim to the democratic peace. The institutional index produces results that are counter-intuitive suggesting that external conflict will increase with the consolidation of political institutions.

The four conflict control variables produce significant results in this model. The minorities at risk variable once again indicates that involvement in MIDs will increase as minority groups located within the state are declared to be "at risk." The state capabilities variable performs differently than in the previous model. However, this is not concerning because state capabilities can work in either a positive or negative fashion meaning that either an increase or decrease in state capabilities can lead to external conflict. States that have more power, meaning they have more capabilities, will often exert their influence in the international system, through armed conflict if necessary. Alternatively, a reduction in state capabilities, or the loss of power, may force states to resort to external conflict as a means to increase their state capabilities and power. This model indicates that militarized interstate disputes will increase as a states power, or capabilities, decrease. The contiguity variable performs in accordance with conflict literature indicating that a state that has more contiguous relationships will more likely be involved in a militarized interstate dispute. The alliance variable also performs differently that in the previous model. Once again, this is not problematic because alliance membership can serve to either increase or mitigate a states involvement in 
militarized interstate disputes. Alliance membership can function as a deterrent to conflict or it can act to draw states into external conflict.

Table 6-4. Time Series Panel Logit for Militarized Interstate Disputes Entered System Late Full Model ${ }^{19}$

\begin{tabular}{|l|l|l|l|}
\hline \multicolumn{1}{|c|}{ Variable } & \multicolumn{1}{|c|}{ Coefficient } & \multicolumn{1}{c|}{ Standard Error } & \multicolumn{1}{|c|}{ Z Value } \\
\hline Polity 2 & -.0432608 & .0421918 & -1.03 \\
\hline Index & .0294865 & .0102159 & $2.89^{* * *}$ \\
\hline Minorities at Risk & .362875 & .1177335 & $3.08^{* * * *}$ \\
\hline State Capabilities & -45.7147 & 32.22855 & $-1.42^{*}$ \\
\hline Contiguity & .2056284 & .0809656 & $2.54^{* * *}$ \\
\hline Alliances & -.242026 & .0166828 & $-1.45^{*}$ \\
\hline Constant & -4.779539 & 1.016526 & $-4.70^{* * * *}$ \\
\hline
\end{tabular}

$\mathrm{n}=87$ cases, 870 observations

Wald $\mathrm{chi}^{2}=37.16$

${ }^{*} \mathrm{p} \leq .10$, one-tailed test

$* * \mathrm{p} \leq .05$, one-tailed test

$* * * \mathrm{p} \leq .01$, one-tailed test

$* * * * \mathrm{p} \leq .001$, one-tailed test

This model does not perform well overall; however, as Table 6-5 displays, it does predict $88 \%$ of the no conflict situations correctly, $34 \%$ of the conflict situations accurately, for a total of $69 \%$ correct for the total observations included in the data set.

\footnotetext{
${ }^{19}$ The inclusion of dichotomous variables for particular countries did not improve the model, so they were not incorporated in the models.
} 
Table 6-5. Predicted Outcomes Militarized Interstate Disputes

\begin{tabular}{|c|c|c|c|}
\hline \multicolumn{4}{|c|}{ Entered System Late } \\
\hline & $\mathbf{0}$ & 1 & Total \\
\hline $\mathbf{0}$ & 491 & 66 & 557 \\
\hline 1 & 208 & 105 & 313 \\
\hline Total & 699 & 171 & 870 \\
\hline
\end{tabular}

As Table 6-6 displays, all of the component variables of the institution index perform inconsistently with hypothesized effects. This model does not provide any support for the institutional threshold theory and its role in democratic consolidation. As the Wald chi ${ }^{2}$ indicate, the models do not perform well. However, any explanatory value is consumed by the conflict control variables. 
Table 6-6. Time Series Panel Logit for Militarized Interstate Disputes Entered System Late Institution Variables

\begin{tabular}{|l|l|l|l|l|}
\hline \multicolumn{1}{|c|}{ Variable } & \multicolumn{1}{|c|}{ Coefficient } & \multicolumn{1}{|c|}{$\begin{array}{c}\text { Standard } \\
\text { Error }\end{array}$} & \multicolumn{1}{|c|}{ Z Value } & Wald chi \\
\hline $\begin{array}{l}\text { Openness of } \\
\text { Exec. Rect. }\end{array}$ & .0296898 & .0323236 & 0.92 & 30.70 \\
\hline $\begin{array}{l}\text { Constraints on the } \\
\text { Chief Executive }\end{array}$ & .0357146 & .0596781 & 0.60 & 30.62 \\
\hline $\begin{array}{l}\text { Legislative } \\
\text { Effectiveness }\end{array}$ & .0148374 & .061183 & 0.24 & 29.90 \\
\hline $\begin{array}{l}\text { Legislative } \\
\text { Selection }\end{array}$ & .1136666 & .0396129 & $2.87^{* * *}$ & 36.26 \\
\hline $\begin{array}{l}\text { Constitutional } \\
\text { Checks }\end{array}$ & .0180224 & .0952869 & 0.19 & 29.92 \\
\hline \begin{tabular}{l} 
Military \\
\hline Electoral System
\end{tabular} & .1230721 & .049141 & $2.50^{* * *}$ & 32.51 \\
\hline Party Legitimacy & .0632111 & .0330678 & $1.91^{* *}$ & 31.02 \\
\hline Press Freedom & .0550279 & .0348326 & $1.58^{* *}$ & 32.80 \\
\hline $\begin{array}{l}\text { Free and Fair } \\
\text { Elections }\end{array}$ & .0277403 & .0336561 & 0.82 & 30.60 \\
\hline $\begin{array}{l}\text { Universal } \\
\text { Suffrage }\end{array}$ & .0310804 & .0094605 & $3.29^{* * * *}$ & 44.98 \\
\hline
\end{tabular}

$\mathrm{n}=87$ cases, 870 observations

${ }^{*} \mathrm{p} \leq .10$, one-tailed test

$* * \mathrm{p} \leq .05$, one-tailed test

$* * * \mathrm{p} \leq .01$, one-tailed test

$* * * * \mathrm{p} \leq .001$, one-tailed test

\section{Rule of Law / Bureaucratic Quality}

The Rule of Law / Bureaucratic Quality data set performs better than the Entered System Late data set which is supported by the strong Wald chi ${ }^{2}$ score. As Table 6-8 indicates, this data set predicts $75 \%$ of the total observations correctly. The model predicts $88 \%$ of the no conflict situations accurately, but only $47 \%$ of the instances of conflict. Presented in Table 6-7, the two independent variables of interest to this dissertation, the institutional index and the level of democratization indicator, once again, 
do not perform well in this model. The level of democratization indicator is not statistically significant; however, it is signed in the proper direction suggesting weak support for Mansfield and Snyder's claim that democratizing states are more war prone than either authoritarian or democratic regimes. The institutional threshold theory, however, does not receive any support from this model since the result is inconsistent with hypothesized effects.

The minorities at risk variable is highly significant indicating that the number of at risk groups within a state will impact the likelihood for involvement in a militarized interstate dispute. The state capabilities variable is strongly significant suggesting that states that have more power are more likely to be involved in external conflict as they demonstrate their power in the international system. The significant contiguity variable provides results suggesting that states that have more neighbors are more likely to be involved in an increased number of MIDs. The only conflict control variable not significant to the model is alliances. However, it does indicate that numerous alliance involvements will lead to an increase in external conflicts. 
Table 6-7. Time Series Panel Logit for Militarized Interstate Disputes Rule of Law / Bureaucratic Quality Full Model ${ }^{20}$

\begin{tabular}{|l|l|l|l|}
\hline \multicolumn{1}{|c|}{ Variable } & \multicolumn{1}{|c|}{ Coefficient } & \multicolumn{1}{|c|}{ Standard Error } & \multicolumn{1}{|c|}{ Value } \\
\hline Polity 2 & -.0075254 & .0254694 & -0.30 \\
\hline Index & .0023034 & .0054418 & 0.42 \\
\hline Minorities at Risk & .2194762 & .047553 & $4.62^{* * * *}$ \\
\hline State Capabilities & 173.1723 & 26.32252 & $6.58^{* * * *}$ \\
\hline Contiguity & .0621903 & .0384635 & $1.62^{*}$ \\
\hline Alliances & .0050141 & .010247 & 0.49 \\
\hline Constant & -2.691036 & .6296854 & $-4.27 * * * *$ \\
\hline
\end{tabular}

$\mathrm{n}=62$ cases, 992 observations

Wald $\mathrm{chi}^{2}=113.28$

${ }^{*} \mathrm{p} \leq .10$, one-tailed test

$* * \mathrm{p} \leq .05$, one-tailed test

$* * * \mathrm{p} \leq .01$, one-tailed test

$* * * * \mathrm{p} \leq .001$, one-tailed test

Table 6-8. Predicted Outcomes Militarized Interstate Disputes

Rule of Law / Bureaucratic Quality

\begin{tabular}{l|ccc} 
& $\mathbf{0}$ & $\mathbf{1}$ & Total \\
\hline $\mathbf{0}$ & 593 & 83 & 676 \\
$\mathbf{1}$ & 167 & 149 & 316 \\
Total & 760 & 232 & 992
\end{tabular}

Approximately half of the component variables of the institutional index, found in

Table 6-9, lend support for the institutional threshold theory in the Rule of Law /

Bureaucratic Quality data set. The rule of law variable returns results that are counter-

intuitive and not consistent with hypothesized effects because the results suggest that as

\footnotetext{
${ }^{20}$ To improve the model, a combination of random and fixed effects regression is used. The following countries are used as dichotomous variables - Brazil, Honduras, Mexico, Nicaragua, and Thailand. The country dummy variables are included in the full model and the models for the institutional variables.
} 
the rule of law becomes more sound the state will participate in more militarized interstate disputes. Although not significant, the bureaucratic quality variable provides weak evidence for the institutional threshold theory suggesting that a professionalized and meritorious bureaucracy will prevent involvement in MIDs.

The openness of executive recruitment indicates the need to allow all politically active members of the population to compete for the chief executive as a means to prevent involvement in external conflict. It is also necessary to constrain the chief executive through accountability and parity organizations, such as the legislative and judicial branches, in an attempt to reduce state involvement in militarized interstate disputes. The significant legislative effectiveness variable indicates the need to have an effective, rather than a rubber-stamp legislature. An effective legislature will serve to lessen state involvement in MIDs. Those states that have a civilian, rather than military government, are more likely to avoid involvement in militarized interstate disputes. Once again, evidence is attained to suggest that parliamentary systems are more likely to be involved in external conflict, which is contrary to democratization literature. For the first time in this chapter, the press freedom variable returns significant results suggesting that a press that can facilitate an open debate arena is likely to prevent involvement in external conflict. The final variable that lends support for the institutional threshold theory is universal suffrage. This demonstrates the need to grant suffrage to all adult members of the society in an attempt to reduce involvement in MIDs.

The legislative selection variable, constitutional checks, party legitimacy, and free and fair elections are the remaining variable that do not supply evidence for the institutional threshold theory. This indicates that as the citizen's ability to elect their 
legislature, constitutional checks and balances, the inclusion of opposition political parties into the political arena, and free and fair elections increase, the level of militarized interstate disputes will also increase. Obviously, these results are counter-intuitive.

Overall, these models perform relatively well. However, much of the explanatory power can be attributed to the conflict control variables.

Table 6-9. Time Series Panel Logit for Militarized Interstate Disputes Rule of Law / Bureaucratic Quality Institution Variables

\begin{tabular}{|l|l|l|l|l|}
\hline \multicolumn{1}{|c|}{ Variable } & \multicolumn{1}{|c|}{ Coefficient } & \multicolumn{1}{|c|}{$\begin{array}{c}\text { Standard } \\
\text { Error }\end{array}$} & \multicolumn{1}{|c|}{ Z Value } & Wald chi $^{2}$ \\
\hline $\begin{array}{l}\text { Openness of } \\
\text { Exec. Rect. }\end{array}$ & -.0208436 & .0202992 & -1.03 & 115.02 \\
\hline $\begin{array}{l}\text { Constraints on the } \\
\text { Chief Executive }\end{array}$ & -.0491732 & .044782 & -1.10 & 121.01 \\
\hline $\begin{array}{l}\text { Legislative } \\
\text { Effectiveness }\end{array}$ & -.049071 & .0367131 & $-1.34^{*}$ & 120.86 \\
\hline $\begin{array}{l}\text { Legislative } \\
\text { Selection }\end{array}$ & .0096164 & .0225618 & 0.43 & 114.69 \\
\hline $\begin{array}{l}\text { Constitutional } \\
\text { Checks }\end{array}$ & .2085929 & .0835384 & $2.50^{* * *}$ & 114.01 \\
\hline $\begin{array}{l}\text { Rule of Law } \\
\text { Military }\end{array}$ & .0231245 & .0358864 & 0.64 & 111.79 \\
\hline Electoral System & .0754335 & .0263792 & -1.26 & 123.14 \\
\hline Party Legitimacy & .0777313 & .0281984 & $2.76^{* * *}$ & 106.66 \\
\hline $\begin{array}{l}\text { Bureaucratic } \\
\text { Quality }\end{array}$ & -.0167373 & .0413834 & -0.40 & 119.42 \\
\hline Press Freedom & -.0439999 & .0285708 & $-1.54^{*}$ & 119.16 \\
\hline $\begin{array}{l}\text { Free and Fair } \\
\text { Elections }\end{array}$ & .0174989 & .0263526 & 0.66 & 116.95 \\
\hline $\begin{array}{l}\text { Universal } \\
\text { Suffrage }\end{array}$ & -.0039284 & .061015 & -0.06 & 115.67 \\
\hline
\end{tabular}

$\mathrm{n}=62$ cases, 992 observations

${ }^{*} \mathrm{p} \leq .10$, one-tailed test

$* * \mathrm{p} \leq .05$, one-tailed test

$* * * \mathrm{p} \leq .01$, one-tailed test

$* * * * \mathrm{p} \leq .001$, one-tailed test 


\section{Regime Change}

The final data set to be discussed, using militarized interstate disputes as the dependent variable, is the Regime Change data set. This data set includes a regime change variable that analyzes minor to severe regime changes. Including the regime change variable in the data set does not significantly alter the overall performance of the model, according the Wald chi ${ }^{2}$ goodness of fit test. The variable returns results suggesting that a state's involvement in militarized interstate disputes will increase with mild regime changes.

As Table 6-10 depicts, evidence is attained to support the institutional threshold theory through the assessment of the institutional index. The index returns significant findings indicating that participation in militarized interstate disputes will lessen as political institutions are strengthened. This verifies the institutional threshold in democratic consolidation. Although the variable is hardly significant, the level of democratization score implies that a decline in democratization will cause involvement in external conflicts. This does not conform to Mansfield and Snyder's contention that democratization will amplify conflict.

All of the conflict control variables are significant in this model. Consistent across this chapter, the minorities at risk variables generates results denoting that militarized interstate dispute involvement will escalate as more groups within a state are declared to be disadvantaged and "at risk." According to the MAR coefficient, minute increases in the number of minorities at risk located within a state will lead to an increase in militarized interstate disputes. The measurement of state power, the state capabilities variable, signifies that states will resort to external conflict as a method to enhance their 
power. Numerous contiguous relationships will lead to a rise in MID participation.

Finally, numerous alliance memberships will most likely cause an upsurge in external conflict since states are committed to defending their allies.

Table 6-10. Time Series Panel Logit for Militarized Interstate Disputes Regime Change Full Model ${ }^{21}$

\begin{tabular}{|l|l|l|l|}
\hline \multicolumn{1}{|c|}{ Variable } & \multicolumn{1}{|c|}{ Coefficient } & \multicolumn{1}{c|}{ Standard Error } & \multicolumn{1}{|c|}{ Z Value } \\
\hline Polity 2 & -.0012509 & .0253924 & -0.05 \\
\hline Index & -.0075051 & .004764 & $-1.58^{*}$ \\
\hline Regime Change & -.1690401 & .0780227 & $-2.17^{* *}$ \\
\hline Minorities at Risk & .2621488 & .0603328 & $4.35^{* * * *}$ \\
\hline State Capabilities & 174.4398 & 53.92622 & $3.23^{* * * *}$ \\
\hline Contiguity & .0681491 & .051147 & $1.33^{*}$ \\
\hline Alliances & .02483 & .0102418 & $2.41^{* * *}$ \\
\hline Constant & -2.37281 & .4795719 & $-4.95^{* * * *}$ \\
\hline
\end{tabular}

$\mathrm{n}=62$ cases, 1178 observations

Wald chi $^{2}=109.33$

${ }^{*} \mathrm{p} \leq .10$, one-tailed test

$* * \mathrm{p} \leq .05$, one-tailed test

$* * * \mathrm{p} \leq .01$, one-tailed test

$* * * * \mathrm{p} \leq .001$, one-tailed test

Including a regime change variable in the model helps generate the best predicted probabilities in the chapter. As Table 6-11 displays, 79\% of the total observations are correctly predicted, $93 \%$ of the no conflict situations, and $42 \%$ of the conflict situation are accurately predicted. The model adequately predicts the situations of peace, yet does

\footnotetext{
${ }^{21}$ To improve the model, a combination of random and fixed effects regression is used. The following countries are used as dichotomous variables - Brazil, Egypt, Mexico, Nicaragua, Niger, Nigeria, South Korea, Thailand, and Turkey. The country dummy variables are included in the full model and the models for the institutional variables.
} 
not predict the conflict situations as well. Although this may be the result of model misspecification, it is a common occurrence to logit analysis.

Table 6-11. Predicted Outcomes Militarized Interstate Disputes

\begin{tabular}{|c|c|c|c|}
\hline & \multicolumn{3}{|c|}{ Regime Change } \\
\hline & $\mathbf{0}$ & 1 & Total \\
\hline $\mathbf{0}$ & 799 & 58 & 857 \\
\hline 1 & 186 & 135 & 321 \\
\hline Total & 985 & 193 & 1178 \\
\hline
\end{tabular}

Only four of the component variables of the institutional index fail to produce evidence supporting the institutional threshold theory. The constraints placed on the chief executive, constitutional checks, free and fair elections, and universal suffrage do not confirm hypothesized effects.

Displayed in Table 6-12, openness of executive recruitment implies the need to elect the chief executive from the political active population to prevent involvement in militarized interstate disputes. An effective and popularly elected legislature indicates the importance of the legislative branch in consolidating democracy and thereby reducing participation in external conflicts.

A civilian, rather than military controlled government, is vital to democratic consolidation and the avoidance of external conflict. Although not significant, parliamentary systems appear to cause MID involvement more quickly than presidential or hybrid electoral systems. The party legitimacy variable indicates the need to include opposition groups in the political arena in order to consolidate democracy and avoid participation in external conflict. Finally, press freedom is significant in democratic consolidation and the prevention of militarized interstate disputes if it can provide for an 
open debate arena. The small coefficients associated with the statistically significant variables indicate that slight decreases in institutional performance will cause greater involvement in militarized interstate disputes. Overall, the inclusion of the regime change variable allows more support to be generated for the institutional index and the institutional threshold theory.

Table 6-12. Time Series Panel Logit for Militarized Interstate Disputes Regime Change Institution Variables

\begin{tabular}{|c|c|c|c|c|}
\hline Variable & Coefficient & $\begin{array}{l}\text { Standard } \\
\text { Error }\end{array}$ & Z Value & Wald chi ${ }^{2}$ \\
\hline $\begin{array}{l}\text { Openness of } \\
\text { Exec. Rect. }\end{array}$ & -.0205801 & .0180393 & -1.14 & 109.50 \\
\hline $\begin{array}{l}\text { Constraints on the } \\
\text { Chief Executive }\end{array}$ & .0392627 & .0495262 & 0.79 & 105.53 \\
\hline $\begin{array}{l}\text { Legislative } \\
\text { Effectiveness }\end{array}$ & -.0317418 & .0334992 & -0.95 & 108.61 \\
\hline $\begin{array}{l}\text { Legislative } \\
\text { Selection }\end{array}$ & -.0338272 & .0170488 & $-1.98 * *$ & 112.44 \\
\hline $\begin{array}{l}\text { Constitutional } \\
\text { Checks }\end{array}$ & 1770259 & .0948967 & $1.87 * *$ & 112.75 \\
\hline Military & -.0647768 & .0230741 & $-2.81^{* * *}$ & 115.17 \\
\hline Electoral System & .0079402 & .0274678 & 0.29 & 109.07 \\
\hline Party Legitimacy & -.0163493 & .0322663 & -0.51 & 106.51 \\
\hline Press Freedom & -.0632702 & .0349469 & $-1.81^{* *}$ & 110.36 \\
\hline $\begin{array}{l}\text { Free and Fair } \\
\text { Elections }\end{array}$ & .0077914 & .0323735 & 0.24 & 106.88 \\
\hline \begin{tabular}{|l|l} 
Universal \\
Suffrage
\end{tabular} & .0734626 & .0921454 & 0.80 & 108.31 \\
\hline $\begin{array}{l}\mathrm{n}=62 \text { cases, } 1178 \\
{ }_{*} \mathrm{p} \leq .10 \text {, one-tailed } \\
* * \mathrm{p} \leq .05 \text {, one-taile } \\
* * * \mathrm{p} \leq .01 \text {, one-tail } \\
* * * * \mathrm{p} \leq .001 \text {, one-t }\end{array}$ & $\begin{array}{l}\text { bbservations } \\
\text { test } \\
\text { d test } \\
\text { ed test } \\
\text { ailed test }\end{array}$ & & & \\
\hline
\end{tabular}




\section{Conclusions}

The objective of this chapter has been to test the second stage of analysis by investigating the relationship that exists between political institutions, a state's level of democratization, and their mutual result on militarized interstate disputes. Due to the restrictions of the data and the necessity to use four different data sets, it is essential to draw conclusions across the chapter. Overall, using militarized interstate disputes as the dependent variable, this chapter provides only limited support for the institutional threshold theory and Mansfield and Snyder's contention that democratizing states are more war prone than any other type of regime. This demonstrates that the democratization process does not have to be intrinsically violent and lead to heightened conflict. Rather, since most of the models have strongly significant conflict control variables, it suggests that states are simply reacting to their environment. Although this evidence does not support Mansfield and Snyder, it is positive findings indicating that states should neither force nor fear democratization

Figure 6-1 contains the outputs for the level of democratization indicator for the entire chapter. This chart indicates that only the 1974 through 2000 model returns evidence consistent with democratization and war literature suggesting that democratizing states, or anocracies, are more likely to be involved in conflict than any other type of regime. The three remaining data sets return evidence consistent with conventional wisdom suggesting that a decrease in the level of democratization will lead to an increase in militarized interstate disputes. 
Figure 6-1. Level of Democratization Indicator Militarized Interstate Disputes

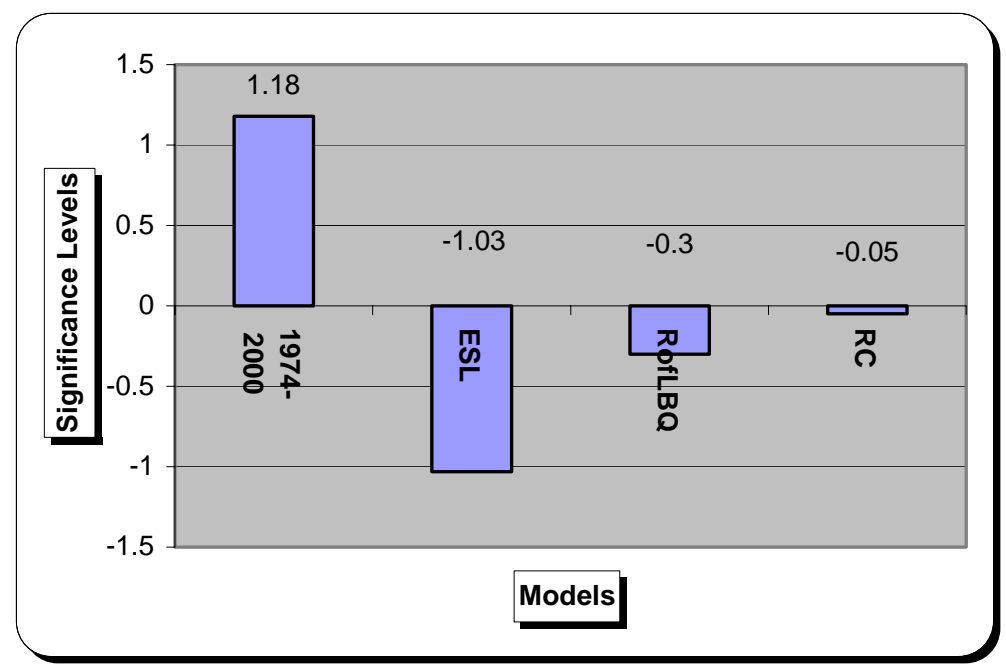

The performance if the institutional index across the four data sets is presented in Figure 6-2. Only two of the four data sets provide evidence indicating that political institutions have a vital function in democratic consolidation and the deterrence of external conflicts. Therefore, limited support is generated for the institutional threshold theory and the role that institutions play in democratic consolidation and the prevention of militarized interstate disputes.

Figure 6-2. Performance of the Institutional Index Militarized Interstate Disputes

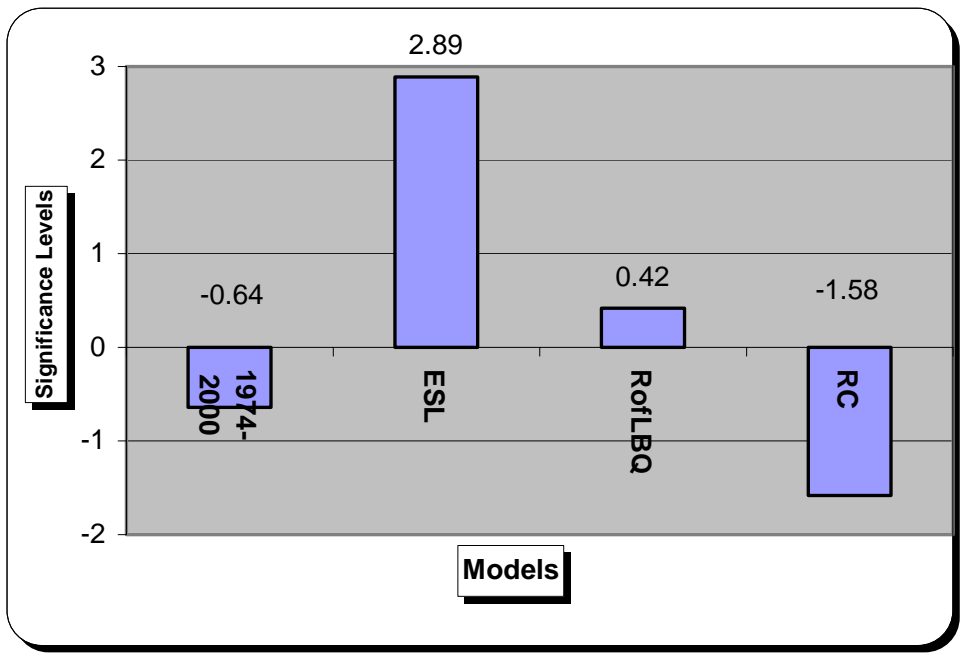


With the exception of the Entered System Late data set, the models perform well overall. Most of the explanatory power of the models, however, can be attributed to the conflict control variables. Consistent across the chapter is the notion that an increase number of minority at risk groups located within a state, more contiguous relationships, numerous alliance memberships, and an escalation in the amount of state capabilities all will lead to more participation in external conflicts through militarized interstate disputes.

As Figure 6-3 displays, because of the variation in the performance of the component variables of the institutional index across the four different datasets, it is difficult to draw conclusions. However, some general statements can be made. An open system of executive recruitment, constraining the chief executive, maintaining an effective legislature, popularly electing the legislative representatives, and embracing a civilian regime, with a subordinate military, are critical governmental institutions to the process of democratic consolidation and the prevention of conflict. It is interesting to note that one similarity throughout the chapter is that the electoral system variable produced findings indicating that parliamentary, not presidential or hybrid, systems are more likely to be involved in external conflict. Regarding the intermediary institutions, it can be concluded that press freedom has vital importance in consolidating democracy and preventing participation in armed conflict. 
Figure 6-3. Performance of the Component Variables of the Institutional Index Militarized Interstate Disputes

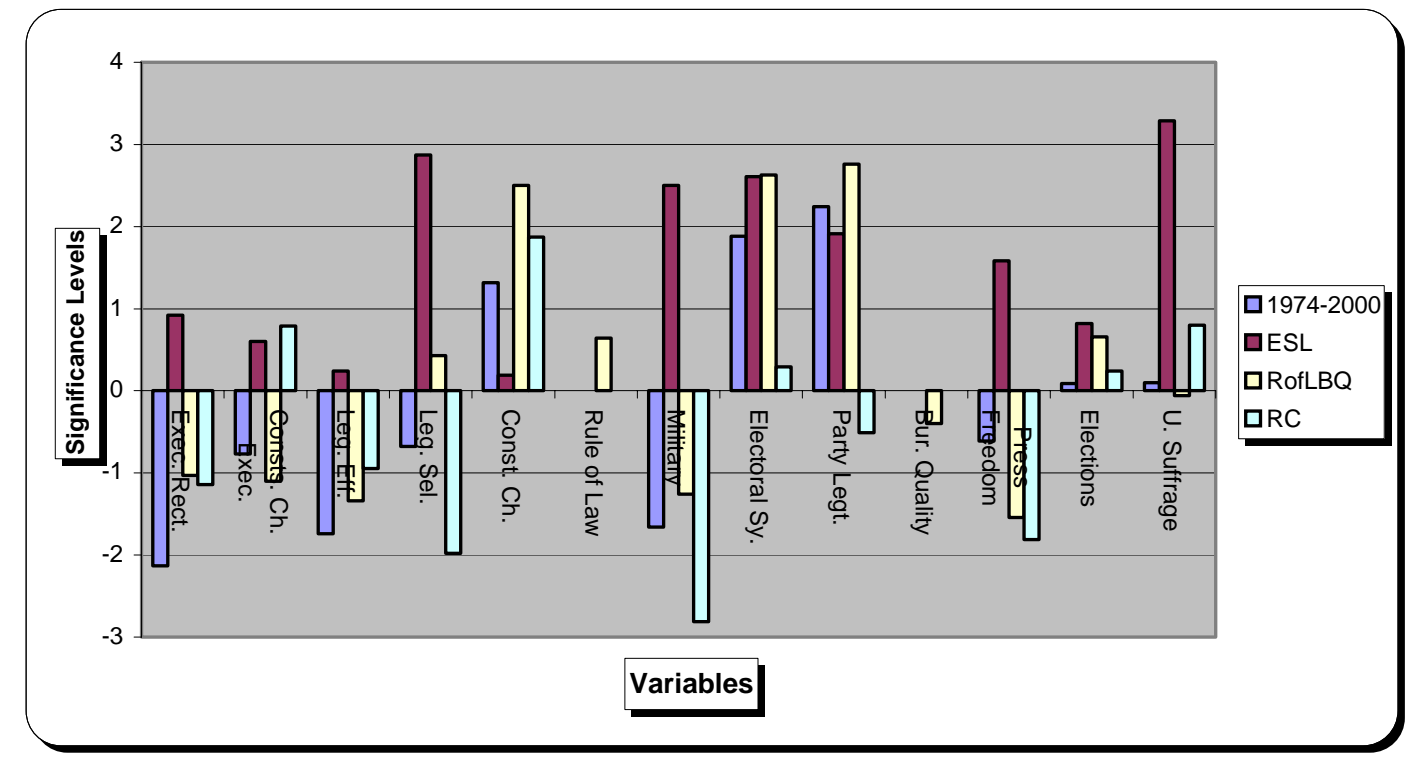

Concerning the two hypotheses that were tested in this chapter, only limited evidence is attained to confirm either hypothesis.

H2. States that are making the transition to democracy while establishing strong political institutions, as evidenced by a higher institutional index score, are less likely to be involved in armed conflict.

Two of the four data sets produce results consistent with the institutional threshold theory providing some evidence to suggest that states must pass through the institution threshold prior to democratic consolidation and the prevention of conflict.

H3. Governmental institutions have a greater positive influence on democratic consolidation than intermediary institutions.

Based upon the findings presented in this chapter, there is minimal indication that governmental institutions are more imperative to democratic consolidation and therefore the avoidance of conflict.

Overall, this chapter did not perform very well. An explanation for the lack of supporting evidence may be that there are only limited observations of conflict, or 
militarized interstate disputes, within the data sets. The next chapter, using armed conflict as the dependent variable, which accounts for both internal and external instances of conflict, provides overwhelming support for the institutional threshold theory. 


\section{Chapter 7 - Armed Conflict}

\section{Introduction}

This third and final quantitative chapter examines the connection between political institutions, the state's level of democratization, and their combined impact on armed conflict. This chapter utilizes the Armed Conflict data set as the dependent variable which is an expansion upon previous literature. The Armed Conflict data set allows for statistical analyses to be performed on both internal and external conflicts. The chapter analyzes the statistical significance of the models through the use of a time series panel regression that employs a combination of random and fixed estimation techniques. Similar to the previous quantitative chapters, analyses are conducted on the four data sets - 1974 through 2000, Entered System Late, Rule of Law / Bureaucratic Quality, and Regime Change. Two models are tested for each data set - the full model and the institutional variables. The full model tests the institutional index, while the component variables of the institutional index are substituted in the institutional variables

models. Two hypotheses are tested in the chapter:

H2. States that are making the transition to democracy while establishing strong political institutions, as evidenced by a higher institutional index score, are less likely to be involved in armed conflict.

H3. Governmental institutions have a greater positive influence on democratic consolidation than intermediary institutions.

\section{Results}

\section{$1974-2000$}

The first data set to be discussed covers the entire time frame of the dissertation, 1974 through 2000, but only includes a subset of seventy countries. The first model to be examined, using a time series panel regression, is the full model that includes the 
institutional index. In this model, almost all of the variables are significant in determining the level of armed conflict in countries that are making the transition to democracy. As can be seen by examining Table 7-1, the level of democratization, or the Polity 2 score, is significant at the .01 level. This indicates that as states attempt to democratize, armed conflict increases. At first glance, this looks counter-intuitive according to conventional wisdom; however, this supports Mansfield and Snyder's argument that state which are making the transition to democracy are more likely to be involved in armed conflict.

The institutional index performs well as it is significant at the .01 level. This suggests that as the validity of political institutions decrease, armed conflict will increase. This performance of the institutional index lends support for the institutional threshold theory. The results indicate that the strengthening of political institutions is a prerequisite to democratic consolidation and validation of the democratic peace.

Several conflict control variables are used within this model. The number of minority groups at risk is highly significant at .001 indicating that armed conflict increases as more groups declared to be minorities at risk are located within that state. The strength of the minorities at risk variable is most likely explaining the internal conflicts found in the dependent variable. The only variable that is not significant in the model is state capabilities which serves as an indirect measure of a state's power. State capabilities can serve to either increase or decrease involvement in armed conflict. States that have higher capabilities will often exert their power through armed conflict in an attempt to increase their power. Alternatively, those states that have reduced capabilities will often resort to armed conflict in order to gain more capabilities, and therefore more 
power. As previously stated, state capabilities is the only variable not significant to this model; however, it is signed in a negative direction which implies that as a state's capabilities decrease, its involvement in armed conflict will increase.

The next conflict control variable to be analyzed is contiguity which is significant at the .05 level. Consistent with conflict literature, this variable suggests that more contiguous relationships will lead to an increase in armed conflict. Alliances, the final conflict control variable, can serve to either mitigate or initiate a state's involvement in armed conflict. In this instance, alliances is significant at .05 denoting that the more alliances a state is involved in, the more likely that state will be involved in armed conflict.

Overall, the model performs relatively well according to the $\mathrm{R}^{2}$ score. It lends support for the two important components of the dissertation - the level of democratization and the institutional index. 
Table 7-1. Time Series Panel Regression for Armed Conflict 1974 through 2000 Full Model ${ }^{22}$

\begin{tabular}{|l|l|l|l|}
\hline \multicolumn{1}{|c|}{ Variable } & \multicolumn{1}{|c|}{ Coefficient } & \multicolumn{1}{c|}{ Standard Error } & \multicolumn{1}{c|}{ Z Value } \\
\hline Polity 2 & .0174156 & .0061986 & $2.81^{* * *}$ \\
\hline Index & -.0041373 & .0013574 & $-3.05^{* * *}$ \\
\hline Minorities at Risk & .1621071 & .0350121 & $4.63^{* * * *}$ \\
\hline State Capabilities & -10.08649 & 10.64065 & -0.95 \\
\hline Contiguity & .0431422 & .0192459 & $2.24^{* *}$ \\
\hline Alliances & .0070029 & .0037442 & $1.87^{* *}$ \\
\hline Constant & .0798842 & .1734375 & 0.46 \\
\hline
\end{tabular}

$\mathrm{n}=70$ cases, 1890 observations

Overall $\mathrm{R}^{2}=0.3365$

Wald $\mathrm{chi}^{2}=137.29$

${ }^{*} \mathrm{p} \leq .10$, one-tailed test

$* * \mathrm{p} \leq .05$, one-tailed test

$* * * \mathrm{p} \leq .01$, one-tailed test

$* * * * \mathrm{p} \leq .001$, one-tailed test

The next model to be analyzed examines the component variables of the institutional index, as opposed to the institutional index in its entirety. This step is necessary to determine which political institutions have an impact on democratic consolidation and therefore on the prevention of armed conflict. It is also necessary to determine if there is a difference between governmental and intermediary institutions in preventing armed conflict.

Table 7-2 indicates that the majority of the component variables of the institutional index are significant in fostering democratic consolidation and the

\footnotetext{
${ }^{22}$ To improve the model, a combination of random and fixed effects regression is used. The following countries are used as dichotomous variables - Cambodia, Chad, Ethiopia, Guatemala, Kenya, Morocco, Myanmar, Nigeria, Philippines, and Sri Lanka. The country dummy variables are included in the full model and the models for the institutional variables.
} 
prevention of armed conflict. Two variables, the openness of executive recruitment and the constraints placed on the chief executive, are used to test the role of the executive branch. Both variables perform well. The openness of executive recruitment is highly significant at the .001 level suggesting that if the politically active population does not have the opportunity to compete through an electoral process, armed conflict will increase as a result. The second executive measure, constraints on the chief executive, is also significant at the .05 level. As constraints, such as oversight by the legislative branch or parity with other accountability groups, decrease, this in turn will lead to an increase in armed conflict. The coefficients indicate that a small decrease in the openness of executive recruitment and a reduction in the constraints placed on the chief executive will lead to an increase in armed conflict.

Two variables are used to measure the role of the legislative branch. An ineffective or non-existent legislature serves to increase armed conflict because this type of legislature cannot exert influence over the executive branch. Legislative effectiveness and legislative selection are both significant at the .01 level. Legislative selection indicates that as the citizen's ability to elect the legislature decreases, armed conflict will increase.

Constitutional checks, which serves as an indirect measure of a state's constitutional checks and balances, is not significant in this particular model. Although not significant, the direction of the constitutional checks variable suggests that as constitutional checks and balances decrease, armed conflict will increase. 
The role of the military is also not significant in this particular model. However, the variable does suggest that as civilian control over the military decreases, armed conflict will increase.

Contrary to previous literature, the electoral system variable suggests that parliamentary systems are more likely to engage in armed conflict. Scholars, namely Linz, imply that presidential systems are more likely than parliamentary systems to decay or breakdown as they transition to democracy. However, this model presents evidence to the contrary.

Of the four intermediary institutions analyzed it the model, only one, universal suffrage, is statistically significant. It is highly significant at the .001 level which demonstrates the importance of granting suffrage to all elements of the population. As elements of the population are denied the right to vote, the level of armed conflict increases. Similarly, although not significant, holding free and fair elections are central in democratic consolidation and the mitigation of armed conflict.

The remaining intermediary institutions, party legitimacy and press freedom, are also not significant. However, party legitimacy does suggest that excluding opposition political parties from participation in the political arena will lead to a rise in armed conflict. Finally, the press freedom variable produces counter-intuitive results suggesting that press freedom is not a critical component of democratic consolidation and the prevention of armed conflict. 
Table 7-2. Time Series Panel Regression for Armed Conflict 1974 through 2000 Institution Variables

\begin{tabular}{|l|l|l|l|l|}
\hline \multicolumn{1}{|c|}{ Variable } & \multicolumn{1}{|c|}{ Coefficient } & \multicolumn{1}{c|}{$\begin{array}{c}\text { Standard } \\
\text { Error }\end{array}$} & \multicolumn{1}{|c|}{$\mathbf{Z}$ Value } & \multicolumn{1}{|c|}{ Overall R $^{2}$} \\
\hline $\begin{array}{l}\text { Openness of Exec. } \\
\text { Recruitment }\end{array}$ & -.0234875 & .0054876 & $-4.28^{* * * *}$ & 0.3383 \\
\hline $\begin{array}{l}\text { Constraints on the } \\
\text { Chief Executive }\end{array}$ & -.0220498 & .0115673 & $-1.91^{* *}$ & 0.3273 \\
\hline $\begin{array}{l}\text { Legislative } \\
\text { Effectiveness }\end{array}$ & -.0278125 & .0093907 & $-2.96^{* * *}$ & 0.3317 \\
\hline $\begin{array}{l}\text { Legislative } \\
\text { Selection }\end{array}$ & -.0128473 & .0047708 & $-2.69^{* * *}$ & 0.3336 \\
\hline $\begin{array}{l}\text { Constitutional } \\
\text { Checks }\end{array}$ & -.0175691 & .0204939 & -0.86 & 0.3282 \\
\hline $\begin{array}{l}\text { Military } \\
\text { Electoral System }\end{array}$ & -.0029637 & .0064057 & -0.46 & 0.3290 \\
\hline Party Legitimacy & -.0078162 & .0072389 & $1.81^{* *}$ & 0.3279 \\
\hline Press Freedom & .0097309 & .0082195 & 1.18 & 0.3255 \\
\hline $\begin{array}{l}\text { Free and Fair } \\
\text { Elections }\end{array}$ & -.0083773 & .006859 & -1.22 & 0.3256 \\
\hline Universal Suffrage & -.0763261 & .0146802 & $-5.20^{* * * *}$ & 0.3455 \\
\hline
\end{tabular}

$\mathrm{n}=70$ cases, 1890 observations

${ }^{*} \mathrm{p} \leq .10$, one-tailed test

$* * \mathrm{p} \leq .05$, one-tailed test

$* * * \mathrm{p} \leq .01$, one-tailed test

$* * * * \mathrm{p} \leq .001$, one-tailed test

\section{Entered System Late}

The Entered System Late data set produces slightly different results than the 1974 through 2000 data set. This data set includes those states that entered the international system after 1974. All countries of interest to the dissertation are analyzed within this data set; however, it covers a truncated time frame of 1991 through 2000. Overall, the model performs well with an $\mathrm{R}^{2}$ score of .40 . 
The results presented in Table 7-3 suggest the level of democratization indicator in this particular model is not significant. It does suggest that as the level of democratization decreases, armed conflict will increase. This is consistent with conventional wisdom, but does not support Mansfield and Snyder's premise that democratizing states are more likely to be involved in armed conflict.

Of primary interest to this dissertation, the institutional index performs well. It is statistically significant at .001. Once again, the institutional index indicates that as the performance of political institutions decrease, armed conflict will increase.

The minorities at risk variable is heavily significant indicating that armed conflict will increase with the number of groups within a country declared to be at risk. The remaining conflict control variables perform differently than the previous model. The state capabilities variable is not statistically significant. The variable signifies that as state capabilities increase, armed conflict will also increase. Although not statistically significant, the contiguity variable returns counter-intuitive results, suggesting that armed conflict will increase as the number of contiguous relationships decrease. Finally, the alliances variable signifies the importance of allying with other states in thwarting armed conflict. The significant results suggest that armed conflict increases as a state's involvement in alliances decrease. 
Table 7-3. Time Series Panel Regression for Armed Conflict Entered System Late Full Model ${ }^{23}$

\begin{tabular}{|l|l|l|l|}
\hline \multicolumn{1}{|c|}{ Variable } & \multicolumn{1}{|c|}{ Coefficient } & \multicolumn{1}{c|}{ Standard Error } & \multicolumn{1}{c|}{ Z Value } \\
\hline Polity 2 & -.0015649 & .0108539 & -0.14 \\
\hline Index & -.0081108 & .0023222 & $-3.49^{* * * *}$ \\
\hline Minorities at Risk & .1270321 & .0276274 & $4.60^{* * * *}$ \\
\hline State Capabilities & 3.714498 & 7.683764 & 0.48 \\
\hline Contiguity & -.0143045 & .0207986 & -0.69 \\
\hline Alliances & -.0072796 & .0043336 & $-1.68^{* *}$ \\
\hline Constant & .9023744 & .2121959 & $4.25^{* * * *}$ \\
\hline
\end{tabular}

$\mathrm{n}=87$ cases, 870 observations

Overall $\mathrm{R}^{2}=0.4046$

Wald $\mathrm{chi}^{2}=211.70$

${ }^{*} \mathrm{p} \leq .10$, one-tailed test

$* * \mathrm{p} \leq .05$, one-tailed test

$* * * \mathrm{p} \leq .01$, one-tailed test

$* * * * \mathrm{p} \leq .001$, one-tailed test

Table 7-4 presents the results for the component variables of the institutional index for the Entered System Late data set. Overall, these models perform relatively well with $\mathrm{R}^{2}$ scores ranging from .37 to .40 .

Of the eleven component variables analyzed, six generate significant results. The significance of the openness of executive recruitment variable suggests that armed conflict will increase if the politically active population is denied access to compete for the chief executive. Both legislative effectiveness and legislative selection are highly significant signifying the importance of an effective and popularly elected legislative

\footnotetext{
${ }^{23}$ To improve the model, a combination of random and fixed effects regression is used. The following countries are used as dichotomous variables - Algeria, Angola, Guatemala, Nigeria, Peru, Philippines, Rwanda, Senegal, Sri Lanka, and Turkey. The country dummy variables are included in the full model and the models for the institutional variables.
} 
branch in consolidating democracy and therefore preventing armed conflict. Unlike the 1974 through 2000 model, constitutional checks returns a significant result specifying the importance of a state's constitutional structure by placing checks and balances on the executive and legislative branches. Excluding political parties from participation in the political arena will lead to a rise in armed conflict. This is evidenced by the strength of the party legitimacy variable. The last variable to produce significant results is universal suffrage indicating that limiting voting privileges to certain segments of society will lead to a rise in armed conflict. The coefficients of these significant variables suggest that small decreases in their institutions performance will lead to an increase in armed conflict.

In this particular data set, constraints placed on the chief executive, the role of the military, the type of electoral system, press freedom, and free and fair elections failed to produce significant results. 
Table 7-4. Time Series Panel Regression for Armed Conflict Entered System Late Institution Variables

\begin{tabular}{|l|l|l|l|l|}
\hline \multicolumn{1}{|c|}{ Variable } & \multicolumn{1}{|c|}{ Coefficient } & \multicolumn{1}{|c|}{$\begin{array}{c}\text { Standard } \\
\text { Error }\end{array}$} & \multicolumn{1}{|c|}{$\mathbf{Z}$ Value } & Overall R $^{2}$ \\
\hline $\begin{array}{l}\text { Openness of Exec. } \\
\text { Recruitment }\end{array}$ & -.0260979 & .009799 & $-2.66^{* * *}$ & 0.3893 \\
\hline $\begin{array}{l}\text { Constraints on the } \\
\text { Chief Executive }\end{array}$ & .0033813 & .0177602 & 0.19 & 0.3784 \\
\hline $\begin{array}{l}\text { Legislative } \\
\text { Effectiveness }\end{array}$ & -.0547966 & .0169428 & $-3.23^{* * * *}$ & 0.3997 \\
\hline $\begin{array}{l}\text { Legislative } \\
\text { Selection }\end{array}$ & -.0325949 & .0100329 & $-3.25^{* * * *}$ & 0.4026 \\
\hline $\begin{array}{l}\text { Constitutional } \\
\text { Checks }\end{array}$ & -.0559156 & .0278308 & $-2.01^{* * *}$ & 0.3856 \\
\hline $\begin{array}{l}\text { Military } \\
\text { Electoral System }\end{array}$ & -.0008942 & .0121472 & -0.07 & 0.3798 \\
\hline Party Legitimacy & -.0417712 & .0120017 & 0.69 & 0.3781 \\
\hline Press Freedom & -.0002851 & .0103796 & -0.03 & 0.3791 \\
\hline $\begin{array}{l}\text { Free and Fair } \\
\text { Elections }\end{array}$ & -.0026006 & .0099109 & -0.26 & 0.3786 \\
\hline Universal Suffrage & -2.2263483 & .0411516 & $-5.50^{* * * *}$ & 0.3922 \\
\hline
\end{tabular}

$\mathrm{n}=87$ cases, 870 observations

${ }^{*} \mathrm{p} \leq .10$, one-tailed test

$* * \mathrm{p} \leq .05$, one-tailed test

$* * * \mathrm{p} \leq .01$, one-tailed test

$* * * * \mathrm{p} \leq .001$, one-tailed test

\section{Rule of Law, Bureaucratic Quality}

Tables 7-5 and 7-6 present the results for the rule of law, bureaucratic quality data set. The two most important variables to this dissertation, the level of democratization and the institutional index, receive overwhelming support from this data set. The level of democratization indicator, the Polity 2 score, is heavily significant, once again lending support for Mansfield and Snyder's argument that democratizing states are more war prone than either democratic or authoritarian states. The institutional threshold theory, 
which is being tested through the institutional index, is overwhelmingly significant denoting the importance of political institutions in the process of democratic consolidation and the mitigation of armed conflict. The inclusion of the rule of law and bureaucratic quality variables strongly influence the significance level of the institutional index. The coefficients for the level of democratization and the institutional index imply that a small move towards democracy will lead to more armed conflict, whereas a minor decrease in the performance of the component variables of the institutional index will produce a rise in armed conflict.

As consistent with previous data sets, the minority at risk variable returns significant results that stress the importance of at risk groups in prompting armed conflict. Contiguity and alliances are both significant in the positive direction indicating that contiguous relationships and alliance involvement will lead to an increase in armed conflict. The only variable that fails to produce significant results is state capabilities. This model performs well overall with an $\mathrm{R}^{2}$ score suggesting that approximately forty-four percent of the variation in the data is being explained. The incorporation of the rule of law and bureaucratic quality variables improves the model specification. However, the data is not available for all countries and years. Therefore, sixty-two states are analyzed during the years 1982 through 1997. 
Table 7-5. Time Series Panel Regression for Armed Conflict Rule of Law / Bureaucratic Quality Full Model ${ }^{24}$

\begin{tabular}{|l|l|l|l|}
\hline \multicolumn{1}{|c|}{ Variable } & \multicolumn{1}{|c|}{ Coefficient } & \multicolumn{1}{c|}{ Standard Error } & \multicolumn{1}{|c|}{ Value } \\
\hline Polity 2 & .0300001 & .0083959 & $3.57 * * * *$ \\
\hline Index & -.0138247 & .0019751 & $-7.00 * * * *$ \\
\hline Minorities at Risk & .1231584 & .0360216 & $3.42^{* * * *}$ \\
\hline State Capabilities & 12.17374 & 13.0708 & 0.93 \\
\hline Contiguity & .0505706 & .0234258 & $2.16^{* *}$ \\
\hline Alliances & .0082713 & .0055045 & $1.50^{*}$ \\
\hline Constant & .8780968 & .2618564 & $3.35^{* * * *}$ \\
\hline
\end{tabular}

$\mathrm{n}=62$ cases, 992 observations

Overall $\mathrm{R}^{2}=0.4381$

Wald $\mathrm{chi}^{2}=156.56$

${ }^{*} \mathrm{p} \leq .10$, one-tailed test

$* * \mathrm{p} \leq .05$, one-tailed test

$* * * \mathrm{p} \leq .01$, one-tailed test

$* * * * \mathrm{p} \leq .001$, one-tailed test

By examining the $\mathrm{R}^{2}$ scores, it is clear that the component variables of the

institutional index for the rule of the law, bureaucratic quality data set perform well. The $\mathrm{R}^{2}$ scores range from .37 to .43 with the rule of law and bureaucratic quality component variables receiving the highest scores lending further evidence for their necessity in democratic consolidation and the prevention of armed conflict.

Similar to the previous models, the openness of executive recruitment, legislative effectiveness, and legislative selection return highly significant results, once again

\footnotetext{
${ }^{24}$ To improve the model, a combination of random and fixed effects regression is used. The following countries are used as dichotomous variables - Angola, Guatemala, Mozambique, Nigeria, Peru, Philippines, Sri Lanka, South Africa. The country dummy variables are included in the full model and the models for the institutional variables.
} 
indicating the importance of governmental institutions as states proceed towards democratic consolidation and the resulting passivity of the democratic peace.

New to this data set, the rule of law and bureaucratic quality variables both return overwhelmingly significant results lending evidence for the need of a well established judicial branch and a professionalized bureaucracy to perform government services. The significance of the rule of law variable indicates that the lack of a strong court system to implement laws and adjudicate disputes will lead to a rise in armed conflict. States that do not have a meritorious and professionalized bureaucracy to implement public policy will also experience an increase in armed conflict.

Party legitimacy once again returns a significant result indicating the lack of or exclusion of political parties may cause an increase in armed conflict. Consistent with previous models, universal suffrage is highly significant, once again denoting the need to include all adult citizens in the voting process. Contrary to previous models, the role of the military returns a significant result suggesting that a military government, in which there is direct military control, will lead to a rise in armed conflict. Also inconsistent with previous models, the free and fair elections variable is significant specifying the need for competitive elections in the consolidation of democracy and the avoidance of armed conflict.

Constraints on the chief executive, constitutional checks, the type of electoral system, and press freedom fail to produce significant results in this particular model. 
Table 7-6. Time Series Panel Regression for Armed Conflict

Rule of Law / Bureaucratic Quality Institution Variables

\begin{tabular}{|l|l|l|l|l|}
\hline \multicolumn{1}{|c|}{ Variable } & \multicolumn{1}{|c|}{ Coefficient } & \multicolumn{1}{|c|}{$\begin{array}{c}\text { Standard } \\
\text { Error }\end{array}$} & \multicolumn{1}{|c|}{$\mathbf{Z}$ Value } & \multicolumn{1}{|c|}{ Overall $\mathbf{R}^{2}$} \\
\hline $\begin{array}{l}\text { Openness of Exec. } \\
\text { Recruitment }\end{array}$ & -.0329423 & .0086144 & $-3.82^{* * * *}$ & 0.3944 \\
\hline $\begin{array}{l}\text { Constraints on the } \\
\text { Chief Executive }\end{array}$ & -.0061623 & .0157761 & -0.39 & 0.3731 \\
\hline $\begin{array}{l}\text { Legislative } \\
\text { Effectiveness }\end{array}$ & -.0585286 & .0143817 & $-4.07^{* * * *}$ & 0.3920 \\
\hline $\begin{array}{l}\text { Legislative } \\
\text { Selection }\end{array}$ & -.0444929 & .0075581 & $-5.89^{* * * *}$ & 0.4047 \\
\hline $\begin{array}{l}\text { Constitutional } \\
\text { Checks }\end{array}$ & .0054455 & .0270276 & 0.20 & 0.3714 \\
\hline $\begin{array}{l}\text { Rule of Law } \\
\text { Military }\end{array}$ & -.1189541 & .0121987 & $-9.75^{* * * *}$ & 0.4308 \\
\hline Electoral System &. .0272123 & .0103097 & $-2.64^{* * *}$ & 0.3968 \\
\hline Party Legitimacy & -.0223637 & .0091546 & $-2.44^{* * *}$ & 0.3893 \\
\hline $\begin{array}{l}\text { Bureaucratic } \\
\text { Quality }\end{array}$ & -.0956131 & .0185054 & $-5.17^{* * * *}$ & 0.4114 \\
\hline Press Freedom & .004568 & .0108957 & 0.42 & 0.3700 \\
\hline $\begin{array}{l}\text { Free and Fair } \\
\text { Elections }\end{array}$ & -.0149516 & .0092542 & $-1.62^{* *}$ & 0.3706 \\
\hline \begin{tabular}{l} 
Universal Suffrage \\
\hline
\end{tabular} & -.2466771 & .0338561 & $-7.29^{* * * *}$ & 0.3935 \\
\hline
\end{tabular}

$\mathrm{n}=62$ cases, 992 observations

$* \mathrm{p} \leq .10$, one-tailed test

$* * \mathrm{p} \leq .05$, one-tailed test

$* * * \mathrm{p} \leq .01$, one-tailed test

$* * * * \mathrm{p} \leq .001$, one-tailed test

\section{Regime Change}

The final data set to be analyzed on the armed conflict dependent variable is the regime change data set. These results can be found in Tables 7-7 and 7-8. Although not significant itself, the inclusion of the regime change variable bolsters the significance level of other variables included in the model. For example, the level of democratization 
indicator is heavily significant at .001, providing further evidence for Mansfield and Snyder's contradictory premise to the democratic peace. All four of the conflict control variables are significant in this particular model. The minorities at risk variable provides further evidence that disadvantaged and discriminated groups are likely to lead to an increase in armed conflict. The measure of a state’s power, state capabilities, produces negative results indicating that states will resort to armed conflict when they are seeing a decline in their power status. The contiguity variable returns results consistent with conventional wisdom suggesting that more contiguous relationships will lead to more armed conflict. The final conflict control variable, alliances, again returns results suggesting that the more alliances a state is involved in, the more likely that state will be drawn into an armed conflict.

Although the inclusion of the regime change variable bolsters the significance levels of other variables in the model, it does not strengthen the score of the institutional index. Of the four data sets tested in this chapter, the institutional index returns the least significant results in the regime change data set. It is, however, still statistically significant, offering evidence for the necessity of consolidating governmental and intermediary institutions in the process of preventing armed conflict. Finally, the regime change variable is not significant, however it does produce results indicating that more dramatic, anti-system regime changes will lead to heightened levels of armed conflict.

This model does not perform as well as the previous, with an $\mathrm{R}^{2}$ score of .25 . The regime change data was not available for all states or years of interest to this dissertation. Therefore, analyses are performed on a subset of countries through the years 1974 through 1992. 
Table 7-7. Time Series Panel Regression for Armed Conflict

Regime Change Full Model ${ }^{25}$

\begin{tabular}{|l|l|l|l|}
\hline \multicolumn{1}{|c|}{ Variable } & \multicolumn{1}{|c|}{ Coefficient } & \multicolumn{1}{c|}{ Standard Error } & \multicolumn{1}{|c|}{ Z Value } \\
\hline Polity 2 & .0430355 & .008021 & $5.37^{* * * *}$ \\
\hline Index & -.0025856 & .0015498 & $-1.67^{* *}$ \\
\hline Regime Change & .0225433 & .0201678 & 1.12 \\
\hline Minorities at Risk & .1763498 & .0435799 & $4.05^{* * * *}$ \\
\hline State Capabilities & -41.12137 & 18.19713 & $-2.26^{* *}$ \\
\hline Contiguity & .0781765 & .0295991 & $2.64^{* * *}$ \\
\hline Alliances & .0060183 & .0045767 & $1.31^{*}$ \\
\hline Constant & .0183414 & .2249147 & 0.08 \\
\hline
\end{tabular}

$\mathrm{n}=62$ cases, 1178 observations

Overall $\mathrm{R}^{2}=0.2589$

Wald $\mathrm{chi}^{2}=98.51$

$* \mathrm{p} \leq .10$, one-tailed test

$* * \mathrm{p} \leq .05$, one-tailed test

$* * * \mathrm{p} \leq .01$, one-tailed test

$* * * * \mathrm{p} \leq .001$, one-tailed test

Including regime change in the models for the component variables of the

institutional index does not furnish many significant results. In fact, only two variables, legislative effectiveness and party legitimacy, are statistically significant. The remaining component variables do not return significant results because the conflict control variables explain the instances of armed conflict in the models.

\footnotetext{
${ }^{25}$ To improve the model, a combination of random and fixed effects regression is used. The following countries are used as dichotomous variables - Guatemala, Morocco, and Philippines. The country dummy variables are included in the full model and the models for the institutional variables.
} 
Table 7-8. Time Series Panel Regression For Armed Conflict

Regime Change Institution Variables

\begin{tabular}{|l|l|l|l|l|}
\hline \multicolumn{1}{|c|}{ Variable } & \multicolumn{1}{|c|}{ Coefficient } & \multicolumn{1}{c|}{$\begin{array}{c}\text { Standard } \\
\text { Error }\end{array}$} & \multicolumn{1}{|c|}{$\mathbf{Z}$ Value } & \multicolumn{1}{|c|}{ Overall R $^{2}$} \\
\hline $\begin{array}{l}\text { Openness of Exec. } \\
\text { Recruitment }\end{array}$ & -.007116 & .0065805 & -1.08 & 0.2555 \\
\hline $\begin{array}{l}\text { Constraints on the } \\
\text { Chief Executive }\end{array}$ & -.0168602 & .0149388 & -1.13 & 0.2568 \\
\hline $\begin{array}{l}\text { Legislative } \\
\text { Effectiveness }\end{array}$ & -.0320112 & .0103695 & $-3.09 * * * *$ & 0.2664 \\
\hline $\begin{array}{l}\text { Legislative } \\
\text { Selection }\end{array}$ & -.0013062 & .0051316 & -0.25 & 0.2501 \\
\hline $\begin{array}{l}\text { Constitutional } \\
\text { Checks }\end{array}$ & -.0315101 & .0261338 & -1.21 & 0.2510 \\
\hline $\begin{array}{l}\text { Military } \\
\text { Electoral System }\end{array}$ & -.0043923 & .0075198 & -0.58 & 0.2525 \\
\hline Party Legitimacy & -.0440002 & .0087779 & 1.16 & 0.2507 \\
\hline Press Freedom & .0030979 & .0119885 & 0.26 & 0.2476 \\
\hline $\begin{array}{l}\text { Free and Fair } \\
\text { Elections }\end{array}$ & -.0033163 & .0094465 & -0.35 & 0.2488 \\
\hline Universal Suffrage & -.0045128 & .0177676 & -0.25 & 0.2493 \\
\hline
\end{tabular}

$\mathrm{n}=62$ cases, 1178 observations

${ }^{*} \mathrm{p} \leq .10$, one-tailed test

$* * \mathrm{p} \leq .05$, one-tailed test

$* * * \mathrm{p} \leq .01$, one-tailed test

$* * * * \mathrm{p} \leq .001$, one-tailed test

\section{Conclusions}

The purpose of this chapter has been to examine the relationship between political institutions, a state's level of democratization, and their collective affect on armed conflict. Because of data limitations and the need to use four different data sets, it is important to draw conclusions across the chapter. As a whole, this chapter provides great supporting evidence for the two most important variables to this dissertation - the level of 
democratization and the institutional index, which provides the means for testing the institutional threshold theory.

As can be seen by examining Figure 7-1, in three of the four models, the level of democratization variable provides support for the democratization and war literature. This lends evidence to the credibility of Mansfield and Snyder's contradictory assumption to the democratic peace, suggesting that states making the transition to democracy are more war prone, both internally and externally, than either democratic or authoritarian states. This empirical evidence provides support for Mansfield and Snyder's claim that the transition process to democracy is inherently violent. It can also be concluded that new and transitional democracies are unstable, which undermines, not validates the principles associated with the democratic peace.

Figure 7-1. Level of Democratization Indicator Armed Conflict

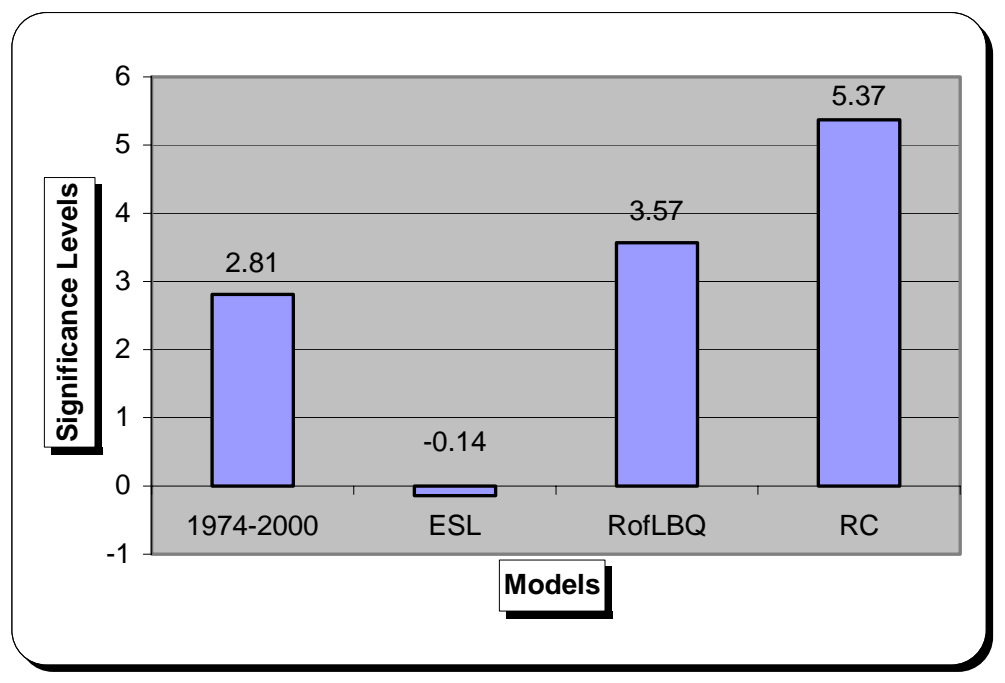

Using armed conflict as the dependent variable, the institutional index also receives overwhelming support from this chapter. The institutional index is significant in all four data sets as can be seen in Figure 7-2. This provides evidence for the institutional threshold theory. States that are able to strengthen a majority of their political institutions 
will pass through the institutional threshold proceeding toward democratic consolidation and therefore the validation of the democratic peace and the passivity that exists amongst democracies. It is imperative to strengthen political institutions. A lack of institutional strengthening means the state is at risk of becoming an entrenched anocracy and remaining at a heightened risk for armed conflict.

Figure 7-2. Performance of the Institutional Index Armed Conflict

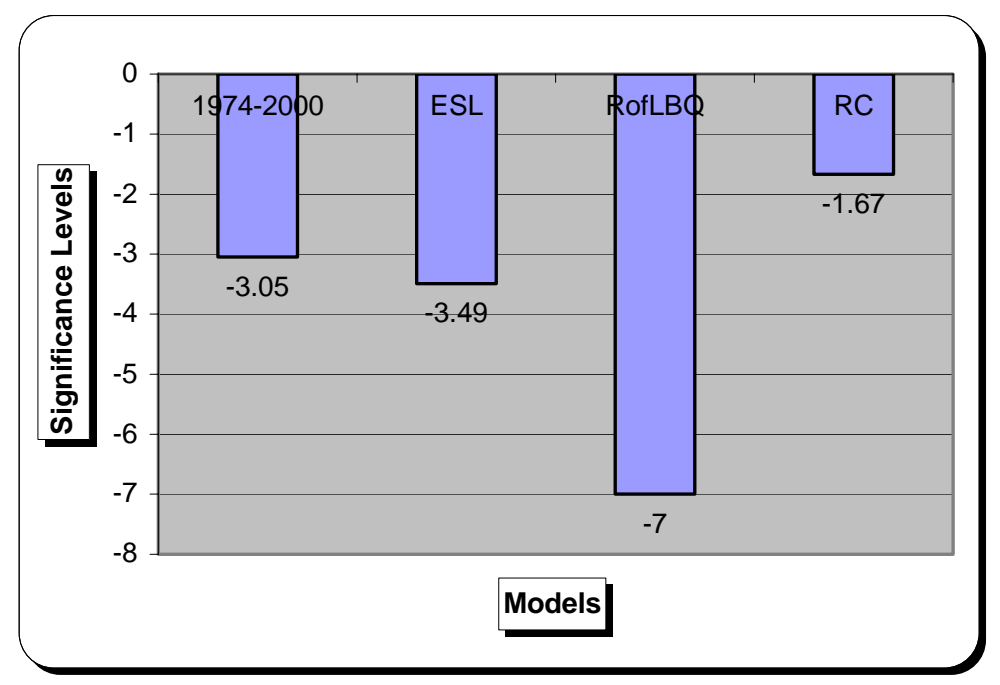

The conflict control variables perform with relative similarity across all data sets. In all four data sets, the minority at risk variable is highly significant indicating the importance of preventing groups from becoming "at risk." States that include a large number of at risk groups are at a higher risk for armed conflict. The performance of state capabilities varies across the four data sets. This is not surprising considering that possessing an abundance or a scarcity of capabilities can lead involvement in armed conflict. Possessing an abundance of capabilities will lead states to exert their influence in the international system as they hope to gain more power. Those states with a scarcity of capabilities will make an effort to increase their power, through armed conflict if necessary. 
Remaining consistent with conflict literature in three of the four data sets, the contiguity variable returns results suggesting that possessing a large quantity of contiguous relationships will lead to an increase in armed conflict. Although alliances can serve to either mitigate or initiate a state’s involvement in armed conflict, this chapter produces evidence indicating that higher alliance membership can actually lead to an increase in armed conflict.

Figure 7-3 indicates that the component variables of the institutional index perform with relative similarity across all data sets. The component variables can be broken into two categories - those that consistently produce significant results, demonstrating their importance in consolidating democracy and preventing armed conflict, and those component variables that fail to consistently produce significant results, signifying their role in democratic consolidation and the prevention of armed conflict is secondary.

The openness of executive recruitment, legislative effectiveness, legislative selection, the rule of law, party legitimacy, bureaucratic quality, and universal suffrage are essential in democratic consolidation and the avoidance of armed conflict. Although not underscoring the importance of these political institutions, the constraints placed on the chief executive, constitutional checks, the role of the military, the type of electoral system, press freedom, and free and fair elections are secondary to the process of democratic consolidation and the mitigation of armed conflict. 
Figure 7-3. Performance of the Component Variables of the Institutional Index Armed Conflict

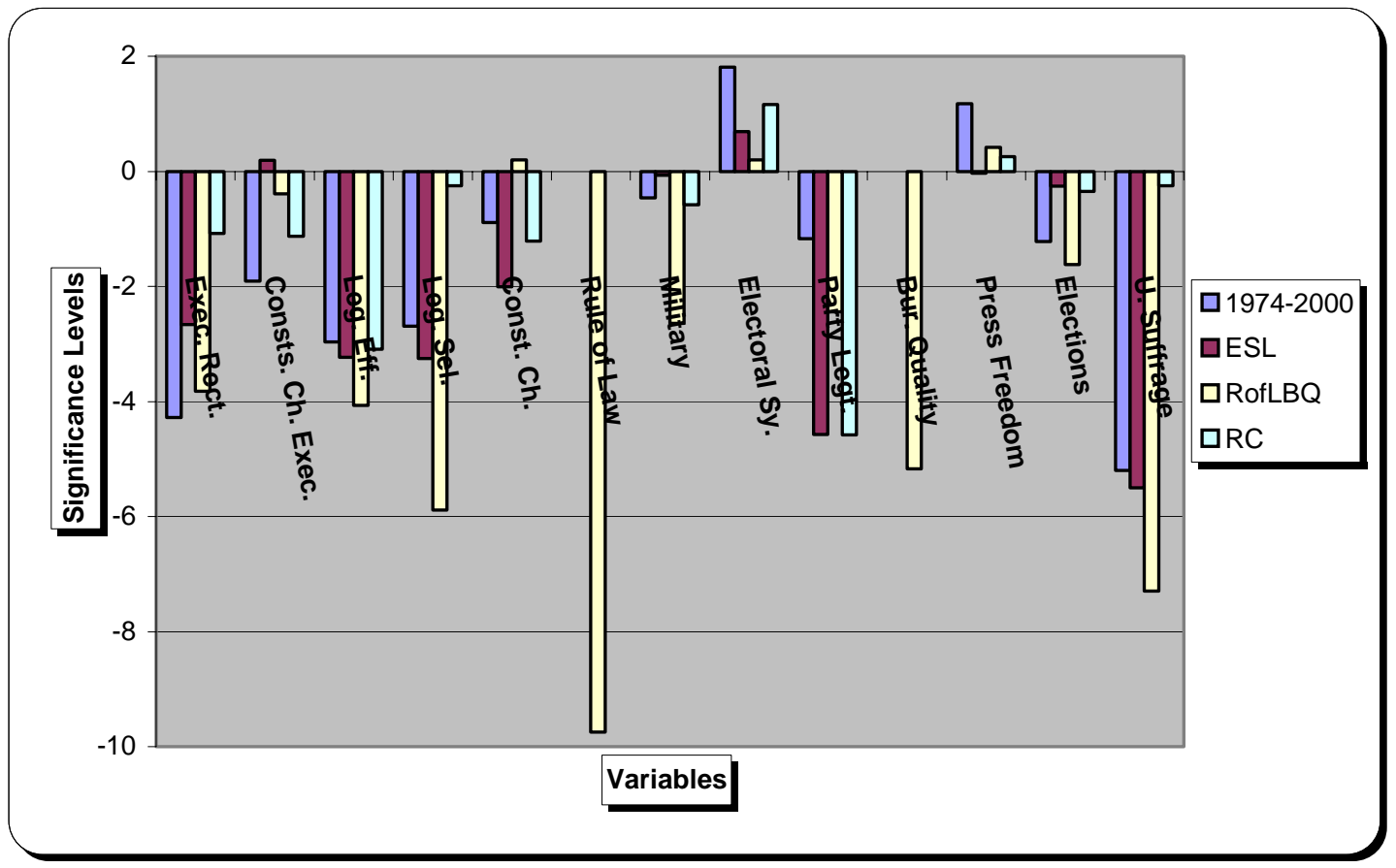

Two hypotheses were tested in this chapter. They are reviewed below.

H2. States that are making the transition to democracy while establishing strong political institutions, as evidenced by a higher institutional index score, are less likely to be involved in armed conflict.

There is strong empirical evidence to suggest that this hypothesis is correct. Political institutions serve as a mitigating factor in the prevention of armed conflict because they allow democratic consolidation to occur and they serve as a regulating mechanism on elites and the masses alike.

States must pass through the institutional threshold before they are able to consolidate democracy and reduce the conflict levels that are inherent in the democratization process. If states can strengthen political institutions, and therefore consolidate democracy, they will lessen the amount of time spent in the democratization 
process, thereby reducing the inherently dangerous and disruptive behavior that accompanies this process.

H3. Governmental institutions have a greater positive influence on democratic consolidation than intermediary institutions.

Hypothesis two asks for a preference to be given between governmental and intermediary institutions. This chapter presents evidence to suggest that both governmental and intermediary institutions are important to the process of democratic consolidation and the deterrence of armed conflict.

Overall, this chapter returns evidence indicating that Mansfield and Snyder are correct in their assertion that democratizing states are more war prone that other types of regimes. However, this is less of a concern because the institutional threshold theory provides the template for generating democratic consolidation and consequently the avoidance of armed conflict within the democratic peace. 


\section{Chapter 8 - Conclusions}

The primary objective of this dissertation has been to reconcile the optimism of the democratic peace with the pessimism of the democratization and war literature by discovering the necessary and sufficient political institutions needed to consolidate democracy and thus authenticate the democratic peace. To reach this objective, several research questions and hypotheses were tested throughout the quantitative chapters of this dissertation. Due to the fact that this dissertation deals with developing countries across a lengthy time frame, it is not surprising that some variables are limited. As a result of these limitations, four different data sets are used across three quantitative chapters. Therefore, it is necessary to draw conclusions across the dissertation and summarize the information by answering the research questions and related hypotheses. This information provides a template concerning the critical political institutions that foster democratic consolidation and in turn validate the democratic peace.

\section{Examination of Research Questions and Hypotheses}

Does the proliferation of democracy really contribute to world peace? The answer to this question is both yes and no. Based upon the findings of the democratic peace, politicians and policy-makers have adopted a foreign policy strategy that involves the promotion of democracy. Democracy promotion does contribute to world peace when mature, liberal democracies are added to the international community. This type of regime possesses the necessary political institutions that validate the democratic peace. However, mature democracies, upon which the democratic peace relies, are often not the result. Instead, a democracy "with adjectives” is often the undesired consequence of 
democracy promotion. This type of state undermines, not validates, the democratic peace.

Is democracy promotion a valuable policy tool to ensure world peace, or are the policy-makers inadvertently advancing conflict as suggested by Mansfield and Snyder? Although some evidence was found to support Mansfield and Snyder, this dissertation finds that they have somewhat overstated their contradictory premise to the democratic peace when they imply that democratizing states are more war prone, both internally and externally, than any either democratic or authoritarian regimes. The two quantitative tests of this premise return somewhat contradictory findings. Different results are found in Chapter Six, which uses militarized interstate disputes to test external conflict as the dependent variable, and Chapter Seven, which employs Armed Conflict to test both internal and external conflict as the dependent variable. Chapter Six peoduces mixed evidence to support Mansfield and Snyder, which indicates that the promotion of democracy should neither be forced nor feared. Chapter Seven does find supporting evidence for Mansfield and Snyder's assertion. However, it may also be argued that states disintegrate from within and this often has spillover effects leading to conflict. Therefore, it can be reasoned that there may be causes other than democratization that produce conflict in these situations.

Which political institutions are necessary to ensure democratic consolidation and by extension prevent armed conflict through the validation of the democratic peace? The primary objective of this dissertation has been to identify the critical political institutions to the process of democratic consolidation. The findings indicate that all thirteen component variables of the institutional index play a critical role in democratic 
consolidation. Although it is possible to identify a smaller number of highly critical institutions, the results suggest that all thirteen serve the function of "lynch pin" institutions. Democratic consolidation rests upon the strengthening of these thirteen political institutions. When democratizing states are constructing their template for democratic consolidation, they must acknowledge the primacy of these political institutions.

Elevating some institutions over others, in terms of the role that the institution plays in fostering democratic consolidation, is difficult, but possible. Table 8.1 portrays the rank order of governmental institutions, Table 8.2 provides the ranking of the intermediary institutions, and Table 8.3 reveals the positioning of all thirteen political institutions ${ }^{26}$. As the tables indicate, constraints on the chief executive and legislative effectiveness are the key governmental institutions, whereas free and fair elections and party legitimacy are the vital intermediary institutions. However, it must be stressed that all thirteen political institutions are critical to democratic consolidation.

Table 8.1 Ranking of Governmental Institutions

\begin{tabular}{|c|}
\hline Constraints on the Chief Executive \\
\hline Legislative Effectiveness \\
\hline Openness of Executive Recruitment \\
\hline Military \\
\hline Constitutional Checks \\
\hline Legislative Selection \\
\hline Electoral System \\
\hline Rule of Law \\
\hline
\end{tabular}

\footnotetext{
${ }^{26}$ The ranking mechanism for the institutions can be found in Appendix 6. The significance level for each institution for each model across the three quantitative chapters was added together and then divided by the total number of observations. This provides a means to compare the institutions.
} 
Table 8.2 Ranking of Intermediary Institutions

\begin{tabular}{|c|}
\hline Free and Fair Elections \\
\hline Party Legitimacy \\
\hline Press Freedom \\
\hline Bureaucratic Quality \\
\hline Universal Suffrage \\
\hline
\end{tabular}

Table 8.3 Ranking of Both Governmental and Intermediary Institutions

\begin{tabular}{|c|}
\hline Constraints on the Chief Executive \\
\hline Free and Fair Elections \\
\hline Party Legitimacy \\
\hline Legislative Effectiveness \\
\hline Openness of Executive Recruitment \\
\hline Press Freedom \\
\hline Military \\
\hline Constitutional Checks \\
\hline Legislative Selection \\
\hline Electoral System \\
\hline Rule of Law \\
\hline Bureaucratic Quality \\
\hline Universal Suffrage \\
\hline
\end{tabular}

Is there a difference between governmental institutions and intermediary institutions in democratic consolidation and the prevention of armed conflict? The simple answer to this research questions is no. Intermediary institutions, or those institutions that act as a conduit between the citizens and the state, are equally as important to democratic consolidation as governmental institutions, or those institutions that hold the formal powers of the government. Based upon the findings of the three quantitative chapters, minute evidence is acquired to suggest that governmental institutions should be privileged over intermediary institutions during the process of 
democratic consolidation. This indicates that both governmental and intermediary institutions should be strengthened as a means to consolidate democracy.

Similar to the threshold that exists for the gross national product and literacy rates, is there an institutional threshold necessary for states to democratize? The institutional threshold theory was tested in the three quantitative chapters through the institutional index. Based upon the statistical significance generated in the quantitative chapters, it can be concluded that a threshold effect does exist for political institutions. States need to strengthen their political institutions as a prerequisite to democratic consolidation. This provides support for the institutional threshold theory suggesting that states must make a conscious effort during the democratizing process to strengthen their political institutions. This strengthening of political institutions will provide for democratic consolidation and in turn validate the democratic peace.

Evidence is found in Chapter Five to further support the idea that a threshold effect exists regarding gross national product and the literacy rate. This indicates that states that acquire a relative high amount of wealth and possess a relatively educated citizenry will be more likely to consolidate democracy and validate the passivity and cooperation of the democratic peace. 
H1. States that are making the transition to democracy while establishing strong political institutions, as evidenced by a higher institutional index score, are more likely to consolidate democracy.

Hypothesis 1 tests the first part of the two-stage analysis by examining the effect that institutions have on democratic consolidation. Chapter Five provides strong empirical evidence to suggest that Hypothesis 1 is correct. States that have focused on regime reforms, through strengthening their political institutions, are more likely to consolidate democracy. Once democracy is consolidated, these states possess the characteristics that validate the democratic peace.

H2. States that are making the transition to democracy while establishing strong political institutions, as evidenced by a higher institutional index score, are less likely to be involved in armed conflict.

Hypothesis 2 tests the second stage of analysis by examining political institutions, the level of democratization, and their impact on conflict. Chapters Six and Seven produce findings to suggest that this hypothesis is also correct. This provides support for the institutional threshold theory because political institutions serve as a mitigating factor in the prevention of armed conflict, they allow for democratic consolidation, and they serve as a regulating mechanism on behavior.

H3. Governmental institutions are more important to democratic consolidation than intermediary institutions.

Although this dissertation differentiates between governmental and intermediary institutions, the findings from the three quantitative chapters do not suggest that governmental institutions are more important than intermediary institutions in the process of democratic consolidation. Strengthening of the thirteen political institutions is necessary for democratic consolidation to occur. Therefore, Hypothesis 3 is rejected. 


\section{Future Research}

Although several important contributions, such as the institutional threshold theory and the operationalization of political institutions through the institutional index, have been added to the international relations and comparative politics literature as a result of this dissertation, there are several issues that remain unresolved that need to be addressed in future research. First, using more advanced quantitative methods, is it possible to temporally test the order of establishing and strengthening political institutions? Second, are there better measures for the component variables of the institutional index? Third, future research should qualitatively examine the institutional threshold theory through the case study technique. Finally, this dissertation's focus concentrates on the state level of analysis through an examination of political institutions. Logical follow-up studies include analyzing the effects of the systemic and individual levels of analysis on countries that are making the transition to democracy.

\section{Final Remarks}

Because the United States, other Western democracies, and intergovernmental organizations, such as the United Nations, see democracy as a prescription for peace, the promotion of democracy promises to be a continuing foreign policy priority. Therefore, the international community must be very precise in promoting mature, liberal, consolidated democracy and wary of other forms of democracy, such as pseudodemocracy, authoritarian democracy, electoral democracy, etc., that may deliver less than desirable outcomes.

When democracy is described in the contemporary world, it is described "with adjectives.” Lets us hope that the democratic states of the future are described with 
mature, liberal, consolidated democracy, rather than pseudodemocracy, semi-democracy, illiberal democracy, authoritarian democracy, quasi democracy, electoral democracy, and so on. 
Appendix 1 -

Classification of Countries Based Upon Their

Level of Democratization in 2000 


\begin{tabular}{|c|c|c|c|c|}
\hline Authoritarian & $\begin{array}{c}\text { Anocracy } \\
\text { (Leaning } \\
\text { Authoritarian) }\end{array}$ & Anocracy & $\begin{array}{c}\text { Anocracy } \\
\text { (Leaning } \\
\text { Democratic) }\end{array}$ & Democracy \\
\hline Azerbaijan & Cameroon & Algeria & Albania & Brazil \\
\hline \multirow[t]{25}{*}{ Myanmar } & $\begin{array}{l}\text { Congo } \\
\text { Brazzaville }\end{array}$ & Angola & Armenia & Chile \\
\hline & Egypt & Burkina Faso & Bangladesh & Croatia \\
\hline & $\begin{array}{l}\text { Equatorial } \\
\text { Guinea }\end{array}$ & Burundi & Benin & $\begin{array}{l}\text { Dominican } \\
\text { Republic }\end{array}$ \\
\hline & Gabon & Cambodia & $\begin{array}{l}\text { Central African } \\
\text { Republic }\end{array}$ & El Salvador \\
\hline & Gambia & Chad & Ecuador & Guatemala \\
\hline & Kazakhstan & Comoros & Estonia & Honduras \\
\hline & Kyrgyzstan & Djibouti & Fiji & Madagascar \\
\hline & Mauritania & Ethiopia & Georgia & Mexico \\
\hline & Morocco & Ghana & Guinea-Bissau & Nicaragua \\
\hline & Pakistan & Guinea & Guyana & Panama \\
\hline & Rwanda & Iran & Ivory Coast & Paraguay \\
\hline & Uganda & Jordan & Macedonia & Philippines \\
\hline & Zimbabwe & Kenya & Mali & Poland \\
\hline & & Liberia & Mozambique & Romania \\
\hline & & Malaysia & Namibia & Russia \\
\hline & & Peru & Nepal & Senegal \\
\hline & & Sierra Leone & Niger & South Africa \\
\hline & & Singapore & Nigeria & South Korea \\
\hline & & Somalia & Sri Lanka & Spain \\
\hline & & Tajikistan & & Taiwan \\
\hline & & Tanzania & & Thailand \\
\hline & & Togo & & Turkey \\
\hline & & Tunisia & & Ukraine \\
\hline & & Yemen & & Yugoslavia \\
\hline & & Zambia & & \\
\hline
\end{tabular}


Appendix 2 - Countries of Interest 


\section{4 through 2000}

Albania
Algeria
Bangladesh
Benin
Brazil
Burkina Faso
Burundi
Cambodia
Cameroon
Central African Republic
Chad
Chile
Congo Brazzaville
Dominican Republic
Ecuador
Egypt
El Salvador
Equatorial Guinea
Ethiopia
Fiji
Gabon
Gambia
Ghana
Guatemala
Guinea
Guinea-Bissau
Guyana
Honduras
Iran
Ivory Coast
Jordan
Kenya
Liberia
Madagascar
Malaysia
Mali
Mauritania
Mexico
Morocco
Myanmar
Nepal
Nicaragua

Niger

Nigeria

Pakistan

Panama

Paraguay

Peru

Philippines

Poland

Romania

Rwanda

Senegal

Sierra Leone

Singapore

Somalia

South Africa

South Korea

Spain

Sri Lanka

Taiwan

Tanzania

Thailand

Togo

Tunisia

Turkey

Uganda

Yugoslavia

Zambia

Zimbabwe 


\section{Entered System Late}

Albania
Algeria
Angola
Armenia
Azerbaijan
Bangladesh
Benin
Brazil
Burkina Faso
Burundi
Cambodia
Cameroon
Central African Republic
Chad
Chile
Comoros
Congo Brazzaville
Croatia
Djibouti
Dominican Republic
Ecuador
Egypt
El Salvador
Equatorial Guinea
Estonia
Ethiopia
Fiji
Gabon
Gambia
Georgia
Ghana
Guatemala
Guinea
Guinea-Bissau
Guyana
Honduras
Iran
Ivory Coast
Jordan
Kazakhstan
Kenya
Kyrgyzstan
Liberia
Macedonia

Madagascar

Malaysia

Mali

Mauritania

Mexico

Morocco

Mozambique

Myanmar

Namibia

Nepal

Nicaragua

Niger

Nigeria

Pakistan

Panama

Paraguay

Peru

Philippines

Poland

Romania

Russia

Rwanda

Senegal

Sierra Leone

Singapore

Somalia

South Africa

South Korea

Spain

Sri Lanka

Taiwan

Tajikistan

Tanzania

Thailand

Togo

Tunisia

Turkey

Uganda

Ukraine

Yemen

Yugoslavia

Zambia

Zimbabwe 


\section{Rule of Law / Bureaucratic Quality}

Albania
Algeria
Angola
Bangladesh
Brazil
Burkina Faso
Cameroon
Chile
Congo Brazzaville
Dominican Republic
Ecuador
Egypt
El Salvador
Ethiopia
Gabon
Gambia
Ghana
Guatemala
Guinea
Guinea-Bissau
Guyana
Honduras
Iran
Ivory Coast
Jordan
Kenya
Liberia
Madagascar
Malaysia
Mali
Mexico
Morocco
Mozambique
Myanmar
Nicaragua
Niger
Nigeria
Pakistan
Panama
Paraguay
Peru
Philippines

Poland

Romania

Senegal

Sierra Leone

Singapore

Somalia

South Africa

South Korea

Spain

Sri Lanka

Taiwan

Tanzania

Thailand

Togo

Tunisia

Turkey

Uganda

Yugoslavia

Zambia

Zimbabwe

Guyana

uras

Iran

Ivory Coast

Jordan

Kenya

Liberia

Madagascar

Malaysia

Mali

Mexico

Morocco

Mozambique

Myanmar

Nicaragua

Niger

Nigeria

Pakistan

Panama

Paraguay

Philippines 


\section{Regime Change}

\begin{tabular}{ll} 
Algeria & Nigeria \\
Bangladesh & Pakistan \\
Benin & Panama \\
Brazil & Paraguay \\
Burkina Faso & Peru \\
Burundi & Philippines \\
Cambodia & Rwanda \\
Cameroon & Senegal \\
Central African Republic & Sierra Leone \\
Chad & Singapore \\
Chile & Somalia \\
Congo Brazzaville & South Korea \\
Dominican Republic & Sri Lanka \\
Ecuador & Tanzania \\
Egypt & Thailand \\
El Salvador & Togo \\
Ethiopia & Tunisia \\
Fiji & Turkey \\
Gabon & Uganda \\
Gambia & Zambia \\
Ghana & Zimbabwe \\
Guatemala & \\
Guinea & \\
Guinea-Bissau & \\
Guyana & \\
Honduras & \\
Iran & \\
Ivory Coast & \\
Jordan & \\
Kenya & \\
Liberia & \\
Madagascar & \\
Malaysia & \\
Mali & \\
Mauritania & \\
Mexico & \\
Morocco & \\
Myanmar & \\
Nepal & \\
Nicaragua & \\
Niger & \\
\hline
\end{tabular}


Appendix 3 - Institutional Index Recoding Scheme 


\begin{tabular}{|c|c|c|c|}
\hline Variable & Explanation & Original & Recoded \\
\hline Openness & $\begin{array}{c}\text { Unregulated } \\
\text { Power Transfers }\end{array}$ & 0 & 0 \\
\hline of & Closed System & 1 & 0 \\
\hline Executive & $\begin{array}{c}\text { Dual Executive }- \\
\text { Designation }\end{array}$ & 2 & 8 \\
\hline Recruitment & $\begin{array}{c}\text { Dual Executive }- \\
\text { Election }\end{array}$ & 3 & 12 \\
\hline & Open System & 4 & 4 \\
\hline
\end{tabular}

\begin{tabular}{|c|c|c|c|}
\hline Variable & Explanation & Original & Recoded \\
\hline Executive & $\begin{array}{c}\text { Unlimited } \\
\text { Authority }\end{array}$ & 1 & 0 \\
\hline Constraints & $\begin{array}{c}\text { Intermediate } \\
\text { Category }\end{array}$ & 2 & 0 \\
\hline & $\begin{array}{c}\text { Slight/Moderate } \\
\text { Limitation }\end{array}$ & 3 & 4 \\
\hline & $\begin{array}{c}\text { Intermediate } \\
\text { Category } \\
\text { Substantial } \\
\text { Limitations }\end{array}$ & 5 & 8 \\
\hline & $\begin{array}{c}\text { Intermediate } \\
\text { Category }\end{array}$ & 6 & 12 \\
\hline & $\begin{array}{c}\text { Executive Parity } \\
\text { or Subordination }\end{array}$ & 7 & 8 \\
\hline
\end{tabular}

\begin{tabular}{|c|c|c|c|}
\hline Variable & Explanation & Original & Recoded \\
\hline Legislative & None & 0 & 0 \\
\hline Effectiveness & Ineffective & 1 & 4 \\
\hline & $\begin{array}{c}\text { Partially } \\
\text { Effective }\end{array}$ & 2 & 8 \\
\hline & Effective & 3 & 12 \\
\hline
\end{tabular}




\begin{tabular}{|c|c|c|c|}
\hline Variable & Explanation & Original & Recoded \\
\hline Legislative & None & 0 & 0 \\
\hline Selection & Nonelective & 1 & 6 \\
\hline & Elective & 2 & 12 \\
\hline
\end{tabular}

\begin{tabular}{|c|c|c|c|}
\hline Variable & Explanation & Original & Recoded \\
\hline Rule & $\begin{array}{c}\text { Depend on } \\
\text { Physical }\end{array}$ & 0 & 0 \\
\hline of & Force or Illegal & 1 & 4 \\
\hline Law & Means to & 2 & 6 \\
\hline & Settle Disputes & 3 & 10 \\
\hline & $\begin{array}{c}\text { Accept } \\
\text { Established }\end{array}$ & 4 & 12 \\
\hline & $\begin{array}{c}\text { Institutions to } \\
\text { Implement Laws }\end{array}$ & 5 & 8 \\
\hline
\end{tabular}

\begin{tabular}{|c|c|c|c|}
\hline Variable & Explanation & Original & Recoded \\
\hline Bureaucratic & Patronage & 0 & 0 \\
\hline Quality & & 1 & 2 \\
\hline & & 2 & 6 \\
\hline & & 3 & 8 \\
\hline & & 4 & 10 \\
\hline & Meritorious & 5 & 12 \\
\hline
\end{tabular}




\begin{tabular}{|c|c|c|c|}
\hline Variable & Explanation & Original & Recoded \\
\hline Party & $\begin{array}{c}\text { No Parties, or all } \\
\text { but Dominant } \\
\text { Party Excluded }\end{array}$ & 0 & 0 \\
\hline Legitimacy & $\begin{array}{c}\text { Significant } \\
\text { Exclusion of } \\
\text { Parties }\end{array}$ & 1 & 8 \\
\hline & $\begin{array}{c}\text { Extremist Parties } \\
\text { Excluded }\end{array}$ & 2 & 12 \\
\hline & $\begin{array}{c}\text { No Parties } \\
\text { Excluded }\end{array}$ & 3 & 8 \\
\hline
\end{tabular}

\begin{tabular}{|c|c|c|c|}
\hline Variable & Explanation & Original & Recoded \\
\hline Type & Civilian & 1 & 12 \\
\hline of & Military-Civilian & 2 & 6 \\
\hline Regime & Military & 3 & 0 \\
\hline & Other & 4 & 0 \\
\hline
\end{tabular}

\begin{tabular}{|c|c|c|c|}
\hline Variable & Explanation & Original & Recoded \\
\hline Press & $\begin{array}{l}\text { Direct Government } \\
\text { Control/Strict } \\
\text { Censorship }\end{array}$ & 4 & 0 \\
\hline \multirow[t]{3}{*}{ Freedom } & $\begin{array}{l}\text { Unable to Function } \\
\text { as a Debate Arena }\end{array}$ & 3 & 4 \\
\hline & $\begin{array}{l}\text { Press Freedom is } \\
\text { Compromised by } \\
\text { Corruption/Unofficial } \\
\text { Influence }\end{array}$ & 2 & 8 \\
\hline & Free Press & 1 & 12 \\
\hline
\end{tabular}




\begin{tabular}{|c|c|c|c|}
\hline Variable & Explanation & Original & Recoded \\
\hline Electoral & $\begin{array}{c}\text { Unelected } \\
\text { Executives }\end{array}$ & $\begin{array}{c}0 \text { (if 1,2,or3 on } \\
\text { EIEC) }\end{array}$ & 0 \\
\hline System & Presidential & 0 & 6 \\
\hline & $\begin{array}{c}\text { Assembly- } \\
\text { Elected President }\end{array}$ & 1 & 12 \\
\hline & Parliamentary & 2 & 6 \\
\hline
\end{tabular}

\begin{tabular}{|c|c|c|c|}
\hline Variable & Explanation & Original & Recoded \\
\hline Free and Fair & $\begin{array}{c}\text { Elections Are } \\
\text { Not Free and Fair }\end{array}$ & 0 & 0 \\
\hline Elections & $\begin{array}{c}\text { Elections Are } \\
\text { Free and Fair }\end{array}$ & 1 & 12 \\
\hline
\end{tabular}

\begin{tabular}{|c|c|c|c|}
\hline Variable & Explanation & Original & Recoded \\
\hline Universal & $\begin{array}{c}\text { Suffrage Not } \\
\text { Extended to all } \\
\text { Groups }\end{array}$ & 0 & 0 \\
\hline Suffrage & $\begin{array}{c}\text { Suffrage } \\
\text { Extended to all } \\
\text { Groups }\end{array}$ & 1 & 12 \\
\hline
\end{tabular}


Appendix 4 - Freedom House Democracy Indicator Outputs 


\section{4 through 2000}

Table 1. Panel Regression for Full Model

\begin{tabular}{|l|l|l|l|}
\hline \multicolumn{1}{|c|}{ Variable } & \multicolumn{1}{|c|}{ Coefficient } & \multicolumn{1}{c|}{ Standard Error } & \multicolumn{1}{|c|}{ Z Value } \\
\hline Index & .0561664 & .0023159 & $24.25^{* * * *}$ \\
\hline GNP per capita & .0000406 & .0000273 & $1.49^{*}$ \\
\hline Literacy & .0106652 & .004455 & $2.39^{* * *}$ \\
\hline Colonial Legacy & -.7477462 & .4138664 & $-1.81^{* *}$ \\
\hline Religion & 1.051311 & .5971136 & $1.76^{* *}$ \\
\hline Minorities at Risk & -.1477894 & .0856262 & $-1.73^{* *}$ \\
\hline Constant & 1.719861 & .3567508 & $4.82^{* * * *}$ \\
\hline
\end{tabular}

$\mathrm{n}=70$ cases, 1680 observations

Overall $\mathrm{R}^{2}=0.4974$

${ }^{*} \mathrm{p} \leq .10$, one-tailed test

$* * \mathrm{p} \leq .05$, one-tailed test

$* * * \mathrm{p} \leq .01$, one-tailed test

$* * * * \mathrm{p} \leq .001$, one-tailed test 
Table 2. Panel Regression For Institution Variables

\begin{tabular}{|l|l|l|l|l|}
\hline \multicolumn{1}{|c|}{ Variable } & \multicolumn{1}{|c|}{ Coefficient } & \multicolumn{1}{|c|}{$\begin{array}{c}\text { Standard } \\
\text { Error }\end{array}$} & \multicolumn{1}{|c|}{$\mathbf{Z}$ Value } & Overall $\mathbf{R}^{2}$ \\
\hline $\begin{array}{l}\text { Openness of Exec. } \\
\text { Recruitment }\end{array}$ & .1608208 & .0151527 & $10.61^{* * * *}$ & 0.2521 \\
\hline $\begin{array}{l}\text { Constraints on the } \\
\text { Chief Executive }\end{array}$ & .379082 & .016003 & $23.69^{* * * *}$ & 0.4903 \\
\hline $\begin{array}{l}\text { Legislative } \\
\text { Effectiveness }\end{array}$ & .4298082 & .0207198 & $20.74^{* * * *}$ & 0.4078 \\
\hline $\begin{array}{l}\text { Legislative } \\
\text { Selection }\end{array}$ & .1445622 & .0138052 & $10.47^{* * * *}$ & 0.2741 \\
\hline $\begin{array}{l}\text { Constitutional } \\
\text { Checks }\end{array}$ & .6344422 & .0489328 & $12.97^{* * * *}$ & 0.3473 \\
\hline $\begin{array}{l}\text { Military } \\
\text { Electoral System }\end{array}$ & .1818465 & .0199373 & $9.12^{* * * *}$ & 0.2680 \\
\hline Party Legitimacy & .3147359 & .0139112 & $22.62^{* * * *}$ & 0.4332 \\
\hline Press Freedom & .3831943 & .0199323 & $19.22^{* * * *}$ & 0.4576 \\
\hline $\begin{array}{l}\text { Free and Fair } \\
\text { Elections }\end{array}$ & .233792 & .0135732 & $17.22^{* * * *}$ & 0.3945 \\
\hline Universal Suffrage & .2287794 & .0450789 & $5.08^{* * * *}$ & 0.2028 \\
\hline
\end{tabular}

$\mathrm{n}=70$ cases, 1680 observations

${ }^{*} \mathrm{p} \leq .10$, one-tailed test

$* * \mathrm{p} \leq .05$, one-tailed test

$* * * \mathrm{p} \leq .01$, one-tailed test

$* * * * \mathrm{p} \leq .001$, one-tailed test 


\section{Entered System Late}

Table 3. Panel Regression for Full Model

\begin{tabular}{|l|l|l|l|}
\hline \multicolumn{1}{|c|}{ Variable } & \multicolumn{1}{|c|}{ Coefficient } & Standard Error & \multicolumn{1}{|c|}{ Z Value } \\
\hline Index & .0345615 & .0043915 & $7.87 * * * *$ \\
\hline GNP per capita & .0001028 & .0000465 & $2.21^{* *}$ \\
\hline Literacy & .0174714 & .0071298 & $2.45^{* * *}$ \\
\hline Colonial Legacy & -1.621026 & .5037114 & $-3.22^{* * * *}$ \\
\hline Religion & 3.085733 & .6712507 & $4.60^{* * * *}$ \\
\hline Minorities at Risk & -.2007146 & .0951471 & $-2.11^{* *}$ \\
\hline Constant & 2.911374 & .5825242 & $5.00^{* * * *}$ \\
\hline
\end{tabular}

$\mathrm{n}=87$ cases, 609 observations

Overall $\mathrm{R}^{2}=0.5025$

${ }^{*} \mathrm{p} \leq .10$, one-tailed test

$* * \mathrm{p} \leq .05$, one-tailed test

$* * * \mathrm{p} \leq .01$, one-tailed test

$* * * * \mathrm{p} \leq .001$, one-tailed test 
Table 4. Panel Regression For Institution Variables

\begin{tabular}{|l|l|l|l|l|}
\hline \multicolumn{1}{|c|}{ Variable } & \multicolumn{1}{|c|}{ Coefficient } & \multicolumn{1}{|c|}{$\begin{array}{c}\text { Standard } \\
\text { Error }\end{array}$} & \multicolumn{1}{|c|}{$\mathbf{Z}$ Value } & Overall $\mathbf{R}^{2}$ \\
\hline $\begin{array}{l}\text { Openness of Exec. } \\
\text { Recruitment }\end{array}$ & .0956361 & .0252381 & $3.79^{* * * *}$ & 0.3294 \\
\hline $\begin{array}{l}\text { Constraints on the } \\
\text { Chief Executive }\end{array}$ & .2304795 & .0307463 & $7.50^{* * * *}$ & 0.5158 \\
\hline $\begin{array}{l}\text { Legislative } \\
\text { Effectiveness }\end{array}$ & .2392625 & .0411147 & $5.82^{* * * *}$ & 0.4395 \\
\hline $\begin{array}{l}\text { Legislative } \\
\text { Selection }\end{array}$ & .0956722 & .0243937 & $3.92^{* * * *}$ & 0.3078 \\
\hline $\begin{array}{l}\text { Constitutional } \\
\text { Checks }\end{array}$ & .178426 & .0616341 & $2.89^{* * *}$ & 0.3298 \\
\hline $\begin{array}{l}\text { Military } \\
\text { Electoral System }\end{array}$ & .0443043 & .0291392 & $1.52^{* *}$ & 0.2966 \\
\hline Party Legitimacy & .060341 & .020675 & $2.92^{* * *}$ & 0.3099 \\
\hline Press Freedom & .0405532 & .020213 & $2.01^{* * *}$ & 0.3090 \\
\hline $\begin{array}{l}\text { Free and Fair } \\
\text { Elections }\end{array}$ & .1031594 & .0191857 & $5.38^{* * * *}$ & 0.4049 \\
\hline Universal Suffrage & .098712 & .0784731 & 1.26 & 0.2707 \\
\hline
\end{tabular}

$\mathrm{n}=87$ cases, 609 observations

${ }^{*} \mathrm{p} \leq .10$, one-tailed test

$*_{* *} \mathrm{p} \leq .05$, one-tailed test

$* * * \mathrm{p} \leq .01$, one-tailed test

$* * * * \mathrm{p} \leq .001$, one-tailed test 


\section{Rule of Law, Bureaucratic Quality}

Table 5. Panel Regression for Full Model

\begin{tabular}{|l|l|l|l|}
\hline \multicolumn{1}{|c|}{ Variable } & \multicolumn{1}{|c|}{ Coefficient } & \multicolumn{1}{c|}{ Standard Error } & \multicolumn{1}{c|}{ Z Value } \\
\hline Index & .0553772 & .0038599 & $14.35^{* * * *}$ \\
\hline GNP per capita & -.0000629 & .0000394 & -0.16 \\
\hline Literacy & .01495 & .0064127 & $2.33^{* * *}$ \\
\hline Colonial Legacy & -1.139053 & .4451077 & $-2.56^{* * *}$ \\
\hline Religion & 1.529027 & .6680115 & $2.29^{* *}$ \\
\hline Minorities at Risk & -.2285463 & .09281 & $-2.46^{* * *}$ \\
\hline Constant & 1.417768 & .5088604 & $2.79^{* * *}$ \\
\hline
\end{tabular}

$\mathrm{n}=62$ cases, 806 observations

Overall $\mathrm{R}^{2}=0.5100$

${ }^{*} \mathrm{p} \leq .10$, one-tailed test

${ }^{* *} \mathrm{p} \leq .05$, one-tailed test

$* * * \mathrm{p} \leq .01$, one-tailed test

$* * * * \mathrm{p} \leq .001$, one-tailed test 
Table 6. Panel Regression For Institution Variables

\begin{tabular}{|l|l|l|l|l|}
\hline \multicolumn{1}{|c|}{ Variable } & \multicolumn{1}{|c|}{ Coefficient } & \multicolumn{1}{|c|}{$\begin{array}{c}\text { Standard } \\
\text { Error }\end{array}$} & \multicolumn{1}{|c|}{ Z Value } & \multicolumn{1}{|c|}{ Overall $\mathbf{R}^{2}$} \\
\hline $\begin{array}{l}\text { Openness of Exec. } \\
\text { Recruitment }\end{array}$ & .1620705 & .0260845 & $6.21^{* * * *}$ & 0.2890 \\
\hline $\begin{array}{l}\text { Constraints on the } \\
\text { Chief Executive }\end{array}$ & .359628 & .0247896 & $14.51^{* * * *}$ & 0.5262 \\
\hline $\begin{array}{l}\text { Legislative } \\
\text { Effectiveness }\end{array}$ & .4524383 & .0369639 & $12.24^{* * * *}$ & 0.4474 \\
\hline $\begin{array}{l}\text { Legislative } \\
\text { Selection }\end{array}$ & .1408657 & .0260989 & $5.40^{* * * *}$ & 0.31242 \\
\hline $\begin{array}{l}\text { Constitutional } \\
\text { Checks }\end{array}$ & .5174379 & .0773861 & $6.69^{* * * *}$ & 0.3934 \\
\hline $\begin{array}{l}\text { Rule of Law } \\
\text { Military }\end{array}$ & .0837933 & .0437014 & $1.92^{* * *}$ & 0.2918 \\
\hline Electoral System & .154191 & .0329904 & $4.67^{* * * *}$ & 0.3254 \\
\hline Party Legitimacy & .3007369 & .0211022 & $14.25^{* * * *}$ & 0.4715 \\
\hline $\begin{array}{l}\text { Bureaucratic } \\
\text { Quality }\end{array}$ & .1171323 & .0624065 & $1.88^{* *}$ & .02902 \\
\hline Press Freedom & .3128338 & .0314452 & $9.95^{* * * *}$ & 0.4495 \\
\hline $\begin{array}{l}\text { Free and Fair } \\
\text { Elections }\end{array}$ & .1918245 & .019883 & $9.65^{* * * *}$ & 0.4476 \\
\hline \begin{tabular}{l} 
Universal Suffrage \\
\hline
\end{tabular} & .4289599 & .1135464 & $3.78^{* * * *}$ & 0.2533 \\
\hline
\end{tabular}

$\mathrm{n}=62$ cases, 806 observations

${ }^{*} \mathrm{p} \leq .10$, one-tailed test

$* * \mathrm{p} \leq .05$, one-tailed test

$* * * \mathrm{p} \leq .01$, one-tailed test

$* * * * \mathrm{p} \leq .001$, one-tailed test 


\section{Regime Change}

Table 7. Panel Regression for Full Model

\begin{tabular}{|l|l|l|l|}
\hline \multicolumn{1}{|c|}{ Variable } & \multicolumn{1}{|c|}{ Coefficient } & \multicolumn{1}{c|}{ Standard Error } & \multicolumn{1}{|c|}{ Value } \\
\hline Index & .0344854 & .0030823 & $11.19^{* * * *}$ \\
\hline GNP per capita & .0001843 & .0000736 & $2.50^{* * *}$ \\
\hline Literacy & .0282307 & .0059774 & $4.72^{* * * *}$ \\
\hline Colonial Legacy & -2.961896 & .4362044 & -0.68 \\
\hline Religion & .1462182 & .6423782 & 0.23 \\
\hline Minorities at Risk & -.1100441 & .0969919 & -1.13 \\
\hline Regime Change & .1033301 & .0459161 & $2.25^{* *}$ \\
\hline Constant & 1.898778 & .4116319 & $4.61^{* * * *}$ \\
\hline
\end{tabular}

$\mathrm{n}=62$ cases, 992 observations

Overall $\mathrm{R}^{2}=0.4269$

${ }^{*} \mathrm{p} \leq .10$, one-tailed test

$* * \mathrm{p} \leq .05$, one-tailed test

$* * * \mathrm{p} \leq .01$, one-tailed test

$* * * * \mathrm{p} \leq .001$, one-tailed test 
Table 8. Panel Regression For Institution Variables

\begin{tabular}{|l|l|l|l|l|}
\hline \multicolumn{1}{|c|}{ Variable } & \multicolumn{1}{|c|}{ Coefficient } & \multicolumn{1}{|c|}{$\begin{array}{c}\text { Standard } \\
\text { Error }\end{array}$} & \multicolumn{1}{|c|}{$\mathbf{Z}$ Value } & Overall $\mathbf{R}^{2}$ \\
\hline $\begin{array}{l}\text { Openness of Exec. } \\
\text { Recruitment }\end{array}$ & .0781652 & .0179569 & $4.35^{* * * *}$ & 0.2553 \\
\hline $\begin{array}{l}\text { Constraints on the } \\
\text { Chief Executive }\end{array}$ & .2551669 & .0229902 & $11.10^{* * * *}$ & 0.4268 \\
\hline $\begin{array}{l}\text { Legislative } \\
\text { Effectiveness }\end{array}$ & .2836623 & .0250866 & $11.31^{* * * *}$ & 0.3657 \\
\hline $\begin{array}{l}\text { Legislative } \\
\text { Selection }\end{array}$ & .0896528 & .0143986 & $6.23^{* * * *}$ & 0.2488 \\
\hline $\begin{array}{l}\text { Constitutional } \\
\text { Checks }\end{array}$ & .1469733 & .0700834 & $2.10^{* * *}$ & 0.2555 \\
\hline $\begin{array}{l}\text { Military } \\
\text { Electoral System }\end{array}$ & .1324287 & .0204601 & $6.47^{* * * *}$ & 0.2577 \\
\hline Party Legitimacy & .2993573 & .0235665 & $12.70^{* * * *}$ & 0.4761 \\
\hline Press Freedom & .3459607 & .0305569 & $11.32^{* * * *}$ & 0.4704 \\
\hline $\begin{array}{l}\text { Free and Fair } \\
\text { Elections }\end{array}$ & .140135 & .01972 & $7.11^{* * * *}$ & 0.3483 \\
\hline Universal Suffrage & -.0444234 & .0506363 & -0.88 & 0.2228 \\
\hline
\end{tabular}

$\mathrm{n}=62$ cases, 992 observations

${ }^{*} \mathrm{p} \leq .10$, one-tailed test

$*_{* *} \mathrm{p} \leq .05$, one-tailed test

$* * * \mathrm{p} \leq .01$, one-tailed test

$* * * * \mathrm{p} \leq .001$, one-tailed test 
Appendix 5 - Change in the Level of Democratization Outputs 
$1974-2000$

Table 1. Panel Regression for Full Model

\begin{tabular}{|l|l|l|l|}
\hline \multicolumn{1}{|c|}{ Variable } & \multicolumn{1}{|c|}{ Coefficient } & \multicolumn{1}{c|}{ Standard Error } & \multicolumn{1}{|c|}{ Z Value } \\
\hline Index & .0041566 & .0019705 & $2.11^{* *}$ \\
\hline GNP per capita & -.000016 & .0000212 & -0.76 \\
\hline Literacy & .0011249 & .0022538 & 0.50 \\
\hline Colonial Legacy & -.3486968 & .1236421 & $-2.82^{* * *}$ \\
\hline Religion & .0998075 & .1800844 & 0.55 \\
\hline Minorities at Risk & .0092781 & .0257495 & 0.36 \\
\hline Constant & .0315741 & .1493153 & 0.21 \\
\hline
\end{tabular}

$\mathrm{n}=70$ cases, 1890 observations

Overall $\mathrm{R}^{2}=0.0079$

${ }^{*} \mathrm{p} \leq .10$, one-tailed test

$* * \mathrm{p} \leq .05$, one-tailed test

$* * * \mathrm{p} \leq .01$, one-tailed test

$* * * * \mathrm{p} \leq .001$, one-tailed test 
Table 2. Panel Regression For Institution Variables

\begin{tabular}{|l|l|l|l|l|}
\hline \multicolumn{1}{|c|}{ Variable } & \multicolumn{1}{|c|}{ Coefficient } & \multicolumn{1}{|c|}{$\begin{array}{c}\text { Standard } \\
\text { Error }\end{array}$} & \multicolumn{1}{|c|}{$\mathbf{Z}$ Value } & Overall R $\mathbf{R}^{2}$ \\
\hline $\begin{array}{l}\text { Openness of Exec. } \\
\text { Recruitment }\end{array}$ & .0240752 & .0098255 & $2.45^{* * *}$ & 0.0087 \\
\hline $\begin{array}{l}\text { Constraints on the } \\
\text { Chief Executive }\end{array}$ & .066124 & .0132998 & $4.97^{* * * *}$ & 0.0184 \\
\hline $\begin{array}{l}\text { Legislative } \\
\text { Effectiveness }\end{array}$ & .0265524 & .0165516 & $1.60^{*}$ & 0.0069 \\
\hline $\begin{array}{l}\text { Legislative } \\
\text { Selection }\end{array}$ & .0058492 & .0109008 & 0.54 & 0.0019 \\
\hline $\begin{array}{l}\text { Constitutional } \\
\text { Checks }\end{array}$ & -.1981179 & .0384737 & $-5.15^{* * * *}$ & 0.0193 \\
\hline $\begin{array}{l}\text { Military } \\
\text { Electoral System }\end{array}$ & -.0429357 & .0133244 & $3.22^{* * * *}$ & 0.0110 \\
\hline Party Legitimacy & .0346402 & .0120471 & $2.88^{* * * *}$ & 0.0099 \\
\hline Press Freedom & -.005551 & .0137273 & -0.40 & 0.0056 \\
\hline $\begin{array}{l}\text { Free and Fair } \\
\text { Elections }\end{array}$ & .0352679 & .0102254 & $3.45^{* * * *}$ & 0.0118 \\
\hline Universal Suffrage & .0076982 & .0290132 & 0.27 & 0.0056 \\
\hline
\end{tabular}

$\mathrm{n}=70$ cases, 1890 observations

${ }^{*} \mathrm{p} \leq .10$, one-tailed test

$* * \mathrm{p} \leq .05$, one-tailed test

$* * * \mathrm{p} \leq .01$, one-tailed test

$* * * * \mathrm{p} \leq .001$, one-tailed test 


\section{Entered System Late}

Table 3. Panel Regression for Full Model

\begin{tabular}{|l|l|l|l|}
\hline \multicolumn{1}{|c|}{ Variable } & \multicolumn{1}{|c|}{ Coefficient } & \multicolumn{1}{c|}{ Standard Error } & \multicolumn{1}{|c|}{ Z Value } \\
\hline Index & .0041312 & .0034614 & 1.19 \\
\hline GNP per capita & .00000352 & .0000246 & 0.14 \\
\hline Literacy & -.0085729 & .0035964 & $-2.38^{* * *}$ \\
\hline Colonial Legacy & -.1689086 & .2053039 & -0.82 \\
\hline Religion & .2672015 & .2733159 & 0.98 \\
\hline Minorities at Risk & .0377815 & .038462 & 0.98 \\
\hline Constant & .5058558 & .3090672 & $1.64^{*}$ \\
\hline
\end{tabular}

$\mathrm{n}=87$ cases, 870 observations

Overall $\mathrm{R}^{2}=0.0087$

${ }^{*} \mathrm{p} \leq .10$, one-tailed test

$* * \mathrm{p} \leq .05$, one-tailed test

$* * * \mathrm{p} \leq .01$, one-tailed test

$* * * * \mathrm{p} \leq .001$, one-tailed test 
Table 4. Panel Regression For Institution Variables

\begin{tabular}{|l|l|l|l|l|}
\hline \multicolumn{1}{|c|}{ Variable } & \multicolumn{1}{|c|}{ Coefficient } & \multicolumn{1}{|c|}{$\begin{array}{c}\text { Standard } \\
\text { Error }\end{array}$} & \multicolumn{1}{|c|}{$\mathbf{Z}$ Value } & Overall R $\mathbf{R}^{2}$ \\
\hline $\begin{array}{l}\text { Openness of Exec. } \\
\text { Recruitment }\end{array}$ & .0615924 & .0172779 & $3.56^{* * * *}$ & 0.0214 \\
\hline $\begin{array}{l}\text { Constraints on the } \\
\text { Chief Executive }\end{array}$ & .0751053 & .0216092 & $3.48^{* * * *}$ & 0.0207 \\
\hline $\begin{array}{l}\text { Legislative } \\
\text { Effectiveness }\end{array}$ & .0224235 & .0290222 & 0.77 & 0.0077 \\
\hline $\begin{array}{l}\text { Legislative } \\
\text { Selection }\end{array}$ & -.0138069 & .0232656 & -0.59 & 0.0074 \\
\hline $\begin{array}{l}\text { Constitutional } \\
\text { Checks }\end{array}$ & -.2232499 & .0542364 & $-4.12^{* * * *}$ & 0.0261 \\
\hline $\begin{array}{l}\text { Military } \\
\text { Electoral System }\end{array}$ & -.0609313 & .0255871 & $2.38^{* * *}$ & 0.0135 \\
\hline Party Legitimacy & .0114998 & .0198766 & 0.58 & 0.0158 \\
\hline Press Freedom & -.0493719 & .0219194 & $-2.25^{* *}$ & 0.0128 \\
\hline $\begin{array}{l}\text { Free and Fair } \\
\text { Elections }\end{array}$ & .034713 & .0142406 & $2.44^{* * *}$ & 0.0138 \\
\hline Universal Suffrage & -.0451254 & .1098804 & -0.41 & 0.0072 \\
\hline
\end{tabular}

$\mathrm{n}=87$ cases, 870 observations

${ }^{*} \mathrm{p} \leq .10$, one-tailed test

$*_{* *} \mathrm{p} \leq .05$, one-tailed test

$* * * \mathrm{p} \leq .01$, one-tailed test

$* * * * \mathrm{p} \leq .001$, one-tailed test 


\section{Rule of Law, Bureaucratic Quality}

Table 5. Panel Regression for Full Model

\begin{tabular}{|l|l|l|l|}
\hline \multicolumn{1}{|c|}{ Variable } & \multicolumn{1}{|c|}{ Coefficient } & \multicolumn{1}{c|}{ Standard Error } & \multicolumn{1}{c|}{ Z Value } \\
\hline Index & .0032099 & .0029132 & 1.10 \\
\hline GNP per capita & -.0000326 & .0000278 & -1.17 \\
\hline Literacy & .0027905 & .0033227 & 0.84 \\
\hline Colonial Legacy & -.3541017 & .1688365 & $-2.10^{* *}$ \\
\hline Religion & .221664 & .2548419 & 0.87 \\
\hline Minorities at Risk & -.0352026 & .035412 & -0.99 \\
\hline Constant & .1823466 & .2532678 & 0.72 \\
\hline
\end{tabular}

$\mathrm{n}=62$ cases, 992 observations

Overall $\mathrm{R}^{2}=0.0113$

${ }^{*} \mathrm{p} \leq .10$, one-tailed test

${ }^{* *} \mathrm{p} \leq .05$, one-tailed test

$* * * \mathrm{p} \leq .01$, one-tailed test

$* * * * \mathrm{p} \leq .001$, one-tailed test 
Table 6. Panel Regression For Institution Variables

\begin{tabular}{|l|l|l|l|l|}
\hline \multicolumn{1}{|c|}{ Variable } & \multicolumn{1}{|c|}{ Coefficient } & \multicolumn{1}{|c|}{$\begin{array}{c}\text { Standard } \\
\text { Error }\end{array}$} & \multicolumn{1}{|c|}{ Z Value } & Overall $\mathbf{R}^{2}$ \\
\hline $\begin{array}{l}\text { Openness of Exec. } \\
\text { Recruitment }\end{array}$ & .0385739 & .0158318 & $2.44^{* * *}$ & 0.0160 \\
\hline $\begin{array}{l}\text { Constraints on the } \\
\text { Chief Executive }\end{array}$ & .0658168 & .0191818 & $3.43^{* * * *}$ & 0.0218 \\
\hline $\begin{array}{l}\text { Legislative } \\
\text { Effectiveness }\end{array}$ & .0209647 & .0262619 & 0.80 & 0.0107 \\
\hline $\begin{array}{l}\text { Legislative } \\
\text { Selection }\end{array}$ & -.0021047 & .0185859 & -0.11 & 0.0101 \\
\hline $\begin{array}{l}\text { Constitutional } \\
\text { Checks }\end{array}$ & -.256803 & .0530009 & $-4.85^{* * * *}$ & 0.0331 \\
\hline Rule of Law & -.0348225 & .0298268 & -1.17 & 0.0114 \\
\hline Military & .0395909 & .021164 & $1.87^{* *}$ & 0.0136 \\
\hline Electoral System & -.0434174 & .0194768 & $-2.23^{* *}$ & 0.0150 \\
\hline Party Legitimacy & .0311285 & .0173713 & $1.79^{* *}$ & 0.0133 \\
\hline $\begin{array}{l}\text { Bureaucratic } \\
\text { Quality }\end{array}$ & -.0035393 & .0323424 & -0.11 & 0.0101 \\
\hline Press Freedom & -.0317501 & .0185863 & $-1.71^{* *}$ & 0.0130 \\
\hline $\begin{array}{l}\text { Free and Fair } \\
\text { Elections }\end{array}$ & .0324714 & .0136638 & $2.38^{* * *}$ & 0.0157 \\
\hline Universal Suffrage & -.008765 & .0557171 & -0.16 & 0.0101 \\
\hline
\end{tabular}

$\mathrm{n}=62$ cases, 992 observations

${ }^{*} \mathrm{p} \leq .10$, one-tailed test

$* * \mathrm{p} \leq .05$, one-tailed test

$* * * \mathrm{p} \leq .01$, one-tailed test

$* * * * \mathrm{p} \leq .001$, one-tailed test 


\section{Regime Change}

Table 7. Panel Regression for Full Model

\begin{tabular}{|l|l|l|l|}
\hline \multicolumn{1}{|c|}{ Variable } & \multicolumn{1}{|c|}{ Coefficient } & \multicolumn{1}{c|}{ Standard Error } & \multicolumn{1}{|c|}{ Value } \\
\hline Index & .0065575 & .002617 & $2.51^{* * *}$ \\
\hline GNP per capita & -.0000201 & .0000536 & -0.37 \\
\hline Literacy & .000285 & .0030756 & 0.09 \\
\hline Colonial Legacy & -.3430476 & .1584371 & $-2.17^{* *}$ \\
\hline Religion & .192331 & .2317515 & 0.83 \\
\hline Minorities at Risk & -.0154885 & .0350544 & -0.44 \\
\hline Regime Change & .3830606 & .0595766 & $6.43^{* * * *}$ \\
\hline Constant & -.1135536 & .1840359 & -0.62 \\
\hline
\end{tabular}

$\mathrm{n}=62$ cases, 1178 observations

Overall $\mathrm{R}^{2}=0.0473$

${ }^{*} \mathrm{p} \leq .10$, one-tailed test

$* * \mathrm{p} \leq .05$, one-tailed test

$* * * \mathrm{p} \leq .01$, one-tailed test

$* * * * \mathrm{p} \leq .001$, one-tailed test 
Table 8. Panel Regression For Institution Variables

\begin{tabular}{|l|l|l|l|l|}
\hline \multicolumn{1}{|c|}{ Variable } & \multicolumn{1}{|c|}{ Coefficient } & \multicolumn{1}{|c|}{$\begin{array}{c}\text { Standard } \\
\text { Error }\end{array}$} & \multicolumn{1}{|c|}{$\mathbf{Z}$ Value } & Overall R $\mathbf{~}^{2}$ \\
\hline $\begin{array}{l}\text { Openness of Exec. } \\
\text { Recruitment }\end{array}$ & .0215016 & .0122612 & $1.75^{* *}$ & 0.0447 \\
\hline $\begin{array}{l}\text { Constraints on the } \\
\text { Chief Executive }\end{array}$ & .0885143 & .0190014 & $4.66^{* * * * *}$ & 0.0597 \\
\hline $\begin{array}{l}\text { Legislative } \\
\text { Effectiveness }\end{array}$ & .0402624 & .0218821 & $1.84^{* *}$ & 0.0450 \\
\hline $\begin{array}{l}\text { Legislative } \\
\text { Selection }\end{array}$ & .0197957 & .0128414 & $1.54^{*}$ & 0.0442 \\
\hline $\begin{array}{l}\text { Constitutional } \\
\text { Checks }\end{array}$ & -.2932017 & .058163 & $-5.04^{* * * *}$ & 0.0626 \\
\hline $\begin{array}{l}\text { Military } \\
\text { Electoral System }\end{array}$ & -.0601387 & .01645 & $3.66^{* * * * *}$ & 0.0530 \\
\hline Party Legitimacy & .0571121 & .0179013 & $3.19^{* * * *}$ & 0.0505 \\
\hline Press Freedom & .0161346 & .0184824 & 0.87 & 0.0428 \\
\hline $\begin{array}{l}\text { Free and Fair } \\
\text { Elections }\end{array}$ & .0613485 & .0156506 & $3.92^{* * * *}$ & 0.0546 \\
\hline Universal Suffrage & .0235602 & .0422037 & 0.56 & 0.0425 \\
\hline
\end{tabular}

$\mathrm{n}=62$ cases, 1178 observations

${ }^{*} \mathrm{p} \leq .10$, one-tailed test

$* * \mathrm{p} \leq .05$, one-tailed test

$* * * \mathrm{p} \leq .01$, one-tailed test

$* * * * \mathrm{p} \leq .001$, one-tailed test 
Appendix 6 - Coding Scheme for the Ordering of the Governmental and Intermediary Institutions 


\begin{tabular}{|c|c|c|c|c|c|c|c|c|c|c|c|c|c|c|c|c|c|c|c|c|c|c|}
\hline $\begin{array}{l}\frac{0}{\partial} \\
\frac{\pi}{2} \\
\frac{\pi}{2}\end{array}$ & 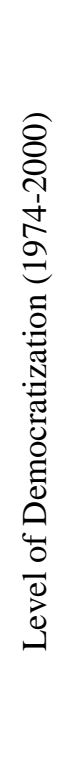 & 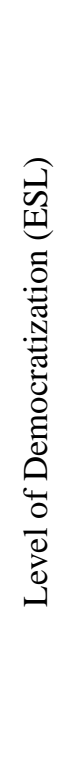 & 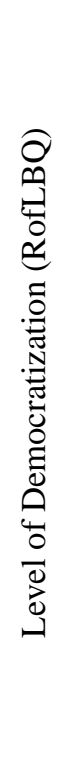 & 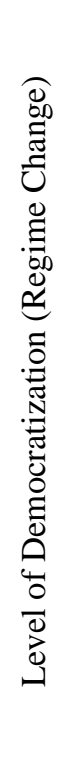 & 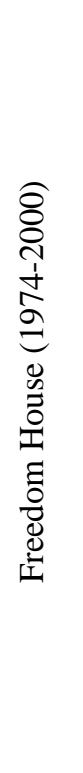 & 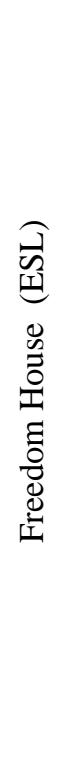 & 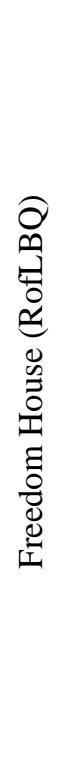 & 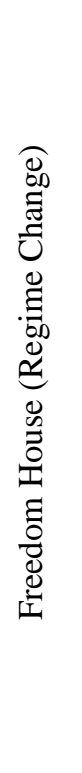 & 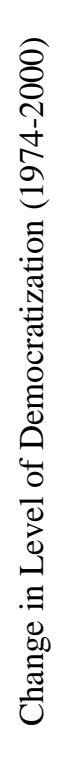 & 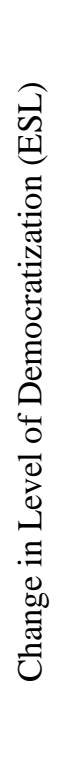 & 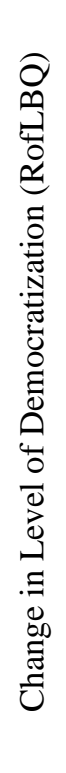 & 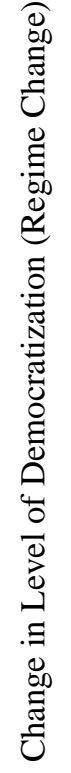 & 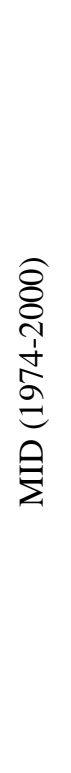 & 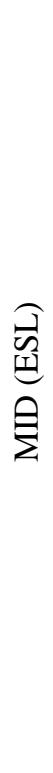 & 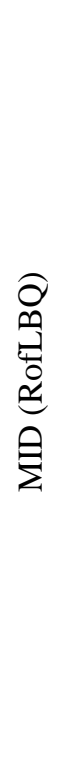 & 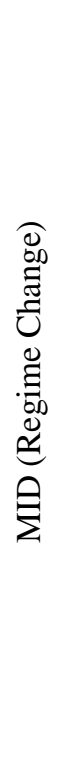 & 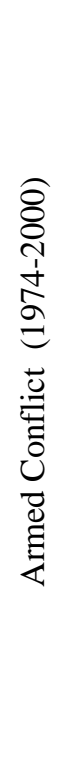 & 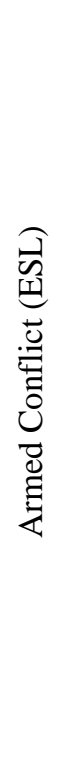 & 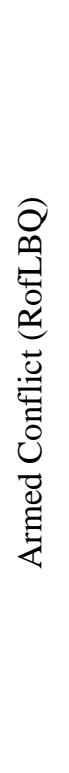 & 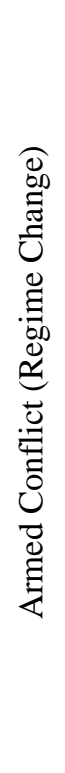 & 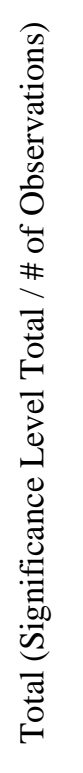 & 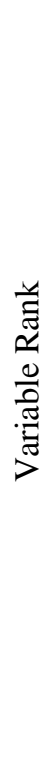 \\
\hline $\begin{array}{l}\text { Open Exec. } \\
\text { Recruitment }\end{array}$ & 18.56 & 14.16 & 15.15 & 14.72 & 10.61 & 3.79 & 6.21 & 4.35 & 2.45 & 3.56 & 2.44 & 1.75 & 2.13 & 0 & 1.03 & 1.14 & 4.28 & 2.66 & 3.82 & 1.08 & 5.69 & 3 \\
\hline $\begin{array}{l}\text { Const. Chief } \\
\text { Executive }\end{array}$ & 68.82 & 31.13 & 48.27 & 54.10 & 23.69 & 7.50 & 14.51 & 11.10 & 4.97 & 3.48 & 3.43 & 4.66 & .77 & 0 & 1.10 & 0 & 1.91 & 0 & .39 & 1.13 & 14.05 & 1 \\
\hline $\begin{array}{l}\text { Legislative } \\
\text { Effective }\end{array}$ & 30.38 & 15.83 & 20.51 & 21.19 & 20.74 & 5.82 & 12.24 & 11.31 & 1.60 & .77 & .80 & 1.84 & 1.74 & 0 & 1.34 & .95 & 2.96 & 3.23 & 4.07 & 3.09 & 8.02 & 2 \\
\hline $\begin{array}{l}\text { Legislative } \\
\text { Selection }\end{array}$ & 11.10 & 8.94 & 5.39 & 9.78 & 10.47 & 3.92 & 5.40 & 6.23 & .54 & 0 & 0 & 1.54 & .68 & 0 & 0 & 1.98 & 2.69 & 3.25 & 5.89 & .25 & 3.90 & 6 \\
\hline $\begin{array}{l}\text { Constitutional } \\
\text { Checks }\end{array}$ & 27.67 & 7.89 & 19.27 & 16.37 & 12.97 & 2.89 & 6.69 & 2.10 & 0 & 0 & 0 & 0 & 0 & 0 & 0 & 0 & .86 & 2.01 & 0 & 1.21 & 5 & 5 \\
\hline Rule of Law & $\mathrm{X}$ & $\mathrm{X}$ & 2.95 & $\mathrm{X}$ & $X$ & $X$ & 1.92 & $X$ & $\mathrm{X}$ & $\mathrm{X}$ & 0 & $\mathrm{X}$ & $\mathrm{X}$ & $\mathrm{X}$ & 0 & $\mathrm{X}$ & $X$ & $\mathrm{X}$ & 9.75 & $\mathrm{X}$ & 2.92 & 8 \\
\hline Military & 13.97 & 10.05 & 11.07 & 14.42 & 11.13 & 7.15 & 7.06 & 6.47 & 3.22 & 2.38 & 1.87 & 3.66 & 1.66 & 0 & 1.26 & 2.81 & .46 & .07 & 2.64 & .58 & 5.10 & 4 \\
\hline $\begin{array}{l}\text { Electoral } \\
\text { System }\end{array}$ & 19.87 & 6.72 & 13.77 & 14.92 & 9.12 & 1.52 & 4.67 & 4.83 & 0 & 0 & 0 & 0 & 0 & 0 & 0 & 0 & 0 & 0 & 0 & 0 & 3.77 & 7 \\
\hline
\end{tabular}




\begin{tabular}{|c|c|c|c|c|c|c|c|c|c|c|c|c|c|c|c|c|c|c|c|c|c|c|}
\hline 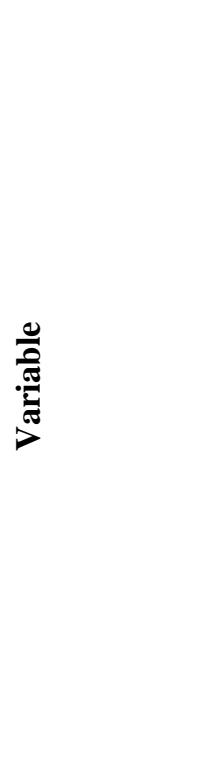 & 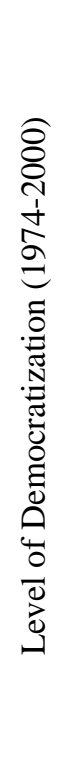 & 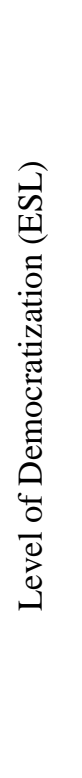 & 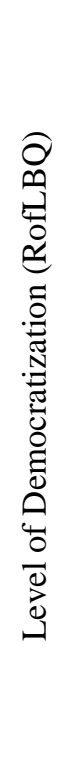 & 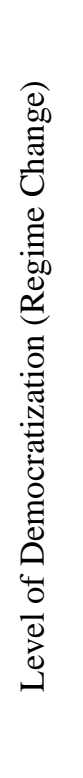 & 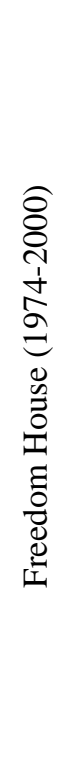 & 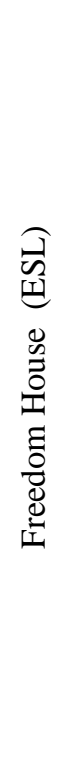 & 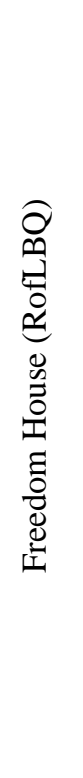 & 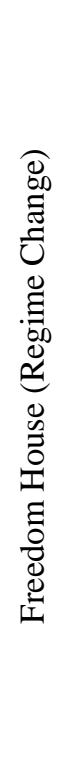 & 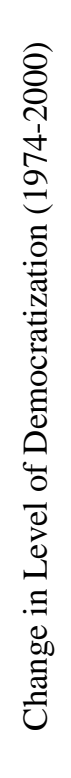 & 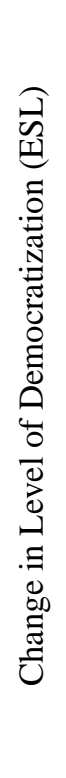 & 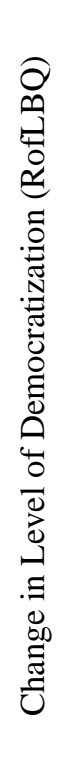 & 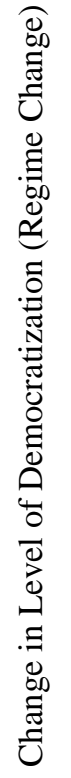 & 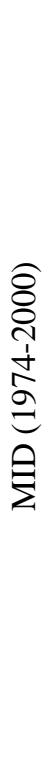 & 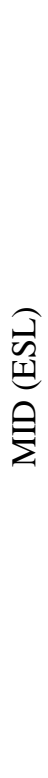 & 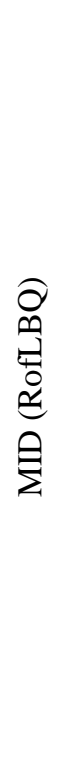 & 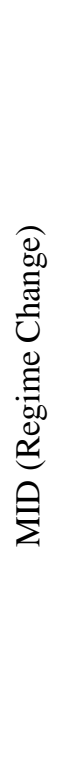 & 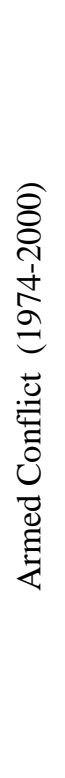 & 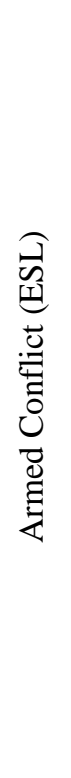 & 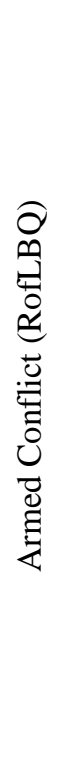 & 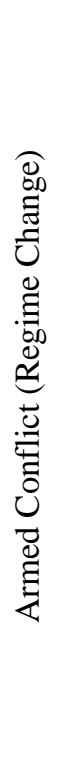 & 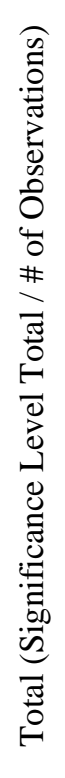 & 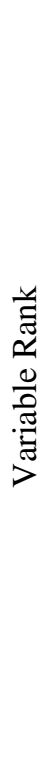 \\
\hline $\begin{array}{l}\text { Party } \\
\text { Legitimacy }\end{array}$ & 35.52 & 11.33 & 26.64 & 25.62 & 22.62 & 2.92 & 14.25 & 12.70 & 2.88 & .58 & 1.79 & 3.19 & 0 & 0 & 0 & .51 & 1.17 & 4.57 & 2.44 & 4.58 & 8.67 & 2 \\
\hline $\begin{array}{l}\text { Bureaucratic } \\
\text { Quality }\end{array}$ & $\mathrm{X}$ & $X$ & 3.49 & $\mathrm{X}$ & $\mathrm{X}$ & $\mathrm{X}$ & 1.88 & $\mathrm{X}$ & $\mathrm{X}$ & $\mathrm{X}$ & 0 & $X$ & $\mathrm{X}$ & $\mathrm{X}$ & .40 & $\mathrm{X}$ & $\mathrm{X}$ & $\mathrm{X}$ & 5.17 & $\mathrm{X}$ & 2.19 & 4 \\
\hline $\begin{array}{l}\text { Press } \\
\text { Freedom }\end{array}$ & 24.15 & 4.05 & 16.32 & 17.42 & 19.22 & 2.01 & 9.95 & 11.32 & 0 & 0 & 0 & .87 & .61 & 0 & 1.54 & 1.81 & 0 & .03 & 0 & 0 & 5.47 & 3 \\
\hline $\begin{array}{l}\text { FreeandFair } \\
\text { Elections }\end{array}$ & 43.88 & 22.35 & 33.24 & 34.96 & 17.22 & 5.38 & 9.65 & 7.11 & 3.45 & 2.44 & 2.38 & 3.92 & 0 & 0 & 0 & 0 & 1.22 & .26 & 1.62 & .35 & 9.47 & 1 \\
\hline $\begin{array}{l}\text { Universal } \\
\text { Suffrage }\end{array}$ & 2.48 & 1.29 & .70 & .70 & 5.08 & 1.26 & 3.78 & 0 & .27 & 0 & 0 & .56 & 0 & 0 & .06 & 0 & 5.20 & 5.50 & 7.29 & .25 & 1.72 & 5 \\
\hline
\end{tabular}




\section{References}

Acemoglu, Daron and James A. Robinson. 2006. Economic Origins of Dictatorship and Democracy. Cambridge: Cambridge UP.

Allison, Paul D. 2001. Missing Data. Sage University Papers Series on Quantitative Application in the Social Science, 07-137. Thousand Oaks, CA: Sage.

Banks, Arthur S. “Cross National Time Series Data Archive.” http://www.databanks.sitehosting.net

Banks, Arthur S., and Thomas C. Muller. 1974-2000. Political Handbook of the World. CSA Publications: Binghamton, NY.

Bates, Robert H. 2001. Prosperity and Violence: The Political Economy of Development. New York: W.W. Norton and Company.

Bealey, Frank. 1999. The Blackwell Dictionary of Political Science. Malden, MA: Blackwell Publishers.

Beck, Nathaniel, Jonathan N. Katz, and Richard Tucker. 1998. “Taking Time Seriously: Time-Series - Cross-Section Analysis with a Binary Dependent Variable.” American Journal of Political Science 42(4):1260-1288.

Bennett, D. Scott and Alan Stam. 2000. “EUGene: A Conceptual Manual.” International Interactions 26: 179-204.

Bentley, Arthur. 1908. The Process of Government. Evanston: Principia Press.

Bermeo, Nancy. 2002. “The Import of Institutions: A New Look at Federalism.” Journal of Democracy 13(2): 96-110.

Bremer, Stuart A. 1992. "Dangerous Dyads: Conditions Affecting the Likelihood of Interstate War, 1816-1965.” Journal of Conflict Resolution 36(2):309-341.

Brubaker, Rogers. 1996. Nationalism Reframed: Nationhood and the National Question in the New Europe. New York: Cambridge UP.

Bueno de Mesquita, Bruce. 1975. “Measuring Systemic Polarity.” Journal of Conflict Resolution 19(2): 187-216.

Bueno de Mesquita, Bruce. 1981. The War Trap. New Haven: Yale UP.

Bueno de Mesquita, Bruce and David Lalman. 1992. War and Reason: Domestic and International Imperatives. New Haven: Yale UP. 
Bueno de Mesquita, Bruce, James D. Morrow, Randolph M. Siverson, and Alastair Smith. 1999. "An Institutional Explanation of the Democratic Peace.” American Political Science Review 93(4): 791-807.

Carothers, Thomas. 1999. Aiding Democracy Abroad: The Learning Curve. Washington, DC: Carnegie Endowment for International Peace.

Clark, Elizabeth Spiro. 2000. "Why Elections Matter.” The Washington Quarterly 23(3): 27-40.

Colomer, Josep M. 2001. Political Institutions: Democracy and Social Choice. New York: Oxford UP.

Cooper, Andrew F. and Thomas Ledler. 2001. "A Model for the Future: The OAS in Peru.” Journal of Democracy 12(4): 123-136.

Correlates of War Project National Material Capabilities Data Documentation, Version 3. http://www.correlatesofwar.org/

Curtis, Gerald L. 1997. “A 'Recipe' for Democratic Development.” Journal of Democracy. 8(3): 139-145.

Dahl, Robert A. 1989. Democracy and its Critics. New Haven: Yale UP.

Dahl, Robert A. 1982. Dilemmas of Pluralist Democracy. New Haven: Yale UP.

Dahl, Robert A. 1971. Polyarchy: Participation and Opposition. New Haven: Yale UP.

Dahl, Robert A. 1998. On Democracy. New Haven: Yale UP.

Dahl, Robert A., ed. 1973. Regimes and Oppositions. New Haven: Yale UP.

Data and Statistical Services (Princeton University Library). "Panel Data" http://dss.princeton.edu/online_help/analysis/panel.htm

Deininger, Klaus and Lyn Squire. 1996. "A New Data Set Measuring Income Inequality.” World Bank Economic Review. 10(3): 565-591.

Diamond, Larry. 1999. Developing Democracy: Toward Consolidation. Baltimore: Johns Hopkins UP.

Diamond, Larry. 1996. “Is the Third Wave Over?” Journal of Democracy 7(3): 20-37.

Diamond, Larry. 2002. "Thinking About Hybrid Regimes: Elections Without Democracy.” Journal of Democracy 13(2): 21-35. 
Diamond, Larry, Juan J. Linz, and Seymour Martin Lipset, eds. 1995. Politics in Developing Countries: Comparing Experiences with Democracy, $2^{\text {nd }}$ Edition. Boulder, CO: Lynne Rienner Publishers.

Diamond, Larry and Marc F. Plattner, eds. 1996. The Global Resurgence of Democracy, $2^{\text {nd }}$ Edition. Baltimore, Johns Hopkins UP.

Diamond, Larry, Marc F. Plattner, Yun-han Chu, and Hung-mao, Tien, eds. 1997. Consolidating the Third Wave Democracies: Regional Challenges. Baltimore: Johns Hopkins UP.

Diamond, Larry, Marc F. Plattner, Yun-han Chu, and Hung-mao, Tien, eds. 1997. Consolidating the Third Wave Democracies: Themes and Perspectives. Baltimore: Johns Hopkins UP.

Dixon, William J. 1994. :Democracy and the Peaceful Settlement of International Conflict.” American Political Science Review 88(1): 14-32.

Doyle, Michael W. 1986. "Liberalism and World Politics." American Political ScienceReview 80(4): 1151-1169.

Ekiert, Grzegorz and Jan Kubik. 1998. "Contentious Politics in New Democracies: East Germany, Hungary, Poland, and Slovakia, 1989-93.” World Politics 50(4): 547581.

Elklit, Jorgen and Palle Svensson. 1997. "What Makes Elections Free and Fair?” Journal of Democracy 8(3): 32-46.

Enterline, Andrew. 1996. “Driving While Democratizing.” International Security 20(4): 183-96.

Enterline, Andrew. 1998. "Regime Changes and Interstate Conflict, 1816-1992." Political Research Quarterly 51(2): 385-409.

Enterline Andrew. 1998. "Regime Changes, Neighborhoods, and Interstate Conflict, 1816-1992.” Journal of Conflict Resolution 42(6): 804-29.

Europa Publications. 1974-2000. The Europa World Year Book. London: Europa Publication Limited.

Faber, Henry and Joanne Gowa. 1995. "Politics and Peace." International Security 20(2): 123-146.

Fomunyoh, Christopher. 2001. "Democratization in Fits and Starts: Francophone Africa in Flux.” Journal of Democracy 12(3): 37-50. 
Freedom in the World 2003: Survey Methodology http://www.freedomhouse.org/template.cfm?page=35\&year=2003

Fried, Robert C. 1967. Comparative Political Institutions. New York: The Macmillan Company.

Friedman, Milton. 1962. Capitalism and Freedom. Chicago: University of Chicago Press.

Gibler, Douglas M., and Meredith Sarkees. Coding Manual for Version 3.0 of the Correlates of War Formal Interstate Alliance Data Set, 1816-2000. http://www.correlatesofwar.org/

Gleditsch, Kristian S. and Michael D. Ward. 1997. "Double Take: A Reexamination of Democracy and Autocracy in Modern Politics.” Journal of Conflict Resolution 41(3): 361-383.

Gleditsch, Kristian S. and Michael D. Ward. 2000. "War and Peace in Space and Time: The Role of Democratization.” International Studies Quarterly 44(March): 1-29.

Gleditsch, Nils Petter, Peter Wallensteen, Mikael Eriksson, Margareta Sollenberg, and Havard Strand. 2002. “Armed Conflict 1946-2001: A New Dataset.” Journal of Peace Research. 39(5): 615-637.

Grugel, Jean. 2002. Democratization: A Critical Introduction. New York: Palgrave.

Gurr, Ted Robert, Monty G. Marshall, and Christian Davenport. 2002. "Minorities at Risk Project.” Center for International Development and Conflict Management. http://www.cidcm.umd.edu/inscr/mar/

Gurr, Ted Robert. 2000. People Versus States: Minorities at Risk in the New Century. Washington, D.C.: United States Institute of Peace Press.

Hagan, Joe D. 1989. "Domestic political regime changes and Third World voting realignments in the United Nations, 1946-1984." International Organization 43 (3): 505-541.

Hayek, Friedrich. 1979. The Political Order of a Free People. Chicago: University of Chicago Press.

Huntington, Samuel P. 1997. "After Twenty Years: The Future of the Third Waves." Journal of Democracy 8(4): 3-12.

Huntington, Samuel P. 1996. "Democracy for the Long Haul.” Journal of Democracy 7(2): 3-13. 
Huntington, Samuel P. 1996. “Democracy's Third Wave.” In The Global Resurgence of Democracy, $2^{\text {nd }}$ Edition. Larry Diamond and Marc F. Plattner, eds. Baltimore: Johns Hopkins UP.

Huntington, Samuel P. 1991-92. “How Countries Democratize.” Political Science Quarterly 106(4): 579-616.

Huntington, Samuel P. 1966. "Political Development and Political Decay.” WorldPolitics 17(3): 378-414.

Huntington, Samuel P. 1968. Political Order in Changing Societies. New Haven: Yale UP.

Huntington, Samuel P. 1991. The Third Wave: Democratization in the Late Twentieth Century. Norman, OK: University of Oklahoma Press.

Huntington, Samuel P. 1984. “Will More Countries Become Democratic?” Political Science Quarterly 99(2): 193-218.

Ikenberry, G. John. 2001. After Victory: Institutions, Strategic Restraint, and the Rebuilding of Order After Major Wars. Princeton, NJ: Princeton UP.

Jaggers, Keith and Ted Robert Gurr. 1995. “Tracking democracy’s Third Wave with the Polity III Data.” Journal of Peace Research 32(4): 469-482.

Jensen, Jane and Susan Phillips. 1996. "Regime Shift: New Citizenship Practices in Canada.” International Journal of Canadian Studies: 118.

Jones, Daniel M., Stuart A. Bremer, and J. David Singer. 1996. "Militarized Interstate Disputes, 1816-1992: Rationale, Coding, Rules, and Empirical Patterns.” Conflict Management and Peace Science 15 (2): 163-213.

Knack, Stephen and Philip Keefer. “IRIS III Dataset.” The PRS Group. http://www.countrydata.com/datasets/

Kuznets, Simon, 1955. "Economic growth and income inequality.” American Economic Review 45(1): 1-28.

Levy, Jack. 1989. "Domestic Politics and War." in The Origin and Prevention of Major Wars, ed. Robert I. Rotberg and Theodore K. Rabb. Cambridge: Cambridge UP.

Lijphart, Arend. 1999. Patterns of Democracy: Government Forms and Performance in Thirty-Six Countries. New Haven: Yale UP.

Linz, Juan J. 1978. The Breakdown of Democratic Regimes: Crisis, Breakdown, and Reequilibration. Baltimore: Johns Hopkins UP. 
Linz, Juan J. 1990. “The Perils of Presidentialism.” Journal of Democracy 1(4): 51-69.

Linz, Juan J. 1990, “The Virtues of Parliamentarism.” Journal of Democracy 1(3): 8491.

Linz, Juan J. and Alfred Stepan. 1996. Problems of Democratic Transition and Consolidation: Southern Europe, South America, and Post-Communist Europe. Baltimore: Johns Hopkins UP.

Linz, Juan J. and Alfred Stepan. 1997. "Toward Consolidated Democracies.” In Consolidating the Third Wave Democracies: Themes and Perspectives. Larry Diamond, Marc F. Plattner, Yun-han Chu, and Hung-mao Tien. Baltimore: Johns Hopkins UP.

Mainwaring, Scott, Guillermo O’Donnell, and J. Samuel Valenzuela, eds. 1992. Issues in Democratic Consolidation: The New South American Democracies in Comparative Perspective. Notre Dame, IN: University of Notre Dame Press.

Mainwaring, Scott. 1998. "Party Systems in the Third Wave." Journal of Democracy 9(3): 67-81.

Mainwaring, Scott. 1999. "The Surprising Resilience of Elected Governments.” Journalof Democracy 10(3):101-114.

Malloy, James M. and Mitchell A. Seligson, eds. 1987. Authoritarians and Democrats: Regime Transition in Latin America. Pittsburgh, PA: University of Pittsburgh Press.

Mansfield, Edward D. and Jack Snyder. 1997. "A Reply to Thompson and Tucker.” Journal of Conflict Resolution 41(3): 457-461.

Mansfield, Edward D. and Jack Snyder. 2002. "Democratic Transitions, Institutional Strength, and War.” International Organization 56(2): 297-337.

Mansfield, Edward D. and Jack Snyder. 1995. "Democratization and the Danger of War.” International Security 20(1): 5-38.

Mansfield, Edward D. and Jack Snyder. 1995. "Democratization and War." Foreign Affairs 74(3): 78-97.

Mansfield, Edward D. and Jack Snyder. 2005. Electing to Fight: Why Emerging Democracies Go to War. Cambridge: MIT Press.

Maoz, Zeev and Bruce Russett. 1993. "Normative and Structural Causes of Democratic Peace, 1946-1986.” American Political Science Review 87(3): 624-637. 
March, James G. and Johan P. Olsen. 1989. Rediscovering Institutions: The Organizational Basis of Politics. New York: Free Press.

March, James G. and Johan P. Olsen. 1984. "The New Institutionalism: Organizational Factors in Political Life.” American Political Science Review 78(3): 734-749.

Markoff, John. 1996. Waves of Democracy: Social Movements and Political Change. London: Pine Forge Press.

Marshall, Monty G. and Keith Jaggers. 2000. "Polity IV Project: Political Regime Characteristics and Transitions, 1800-1999.” Center for International Development and Conflict Management. www.bsos.umd.edu/cidcm/inscr/polity

Mattes, Robert B. 2002. "South Africa: Democracy Without the People." Journal of Democracy 13(1): 22-36.

Mayo, H.B. 1962. "How Can We Justify Democracy?” American Political Science Review 56(3): 555-566.

McFaul, Michael. 2000. "Russian Democracy: Still Not a Lost Cause.” The Washington Quarterly 23(1): 161-172.

Mishler, William and Richard Rose. 1997. "Trust, Distrust, and Skepticism: Popular Evaluations of Civil and Political Institutions in Post-Communist Societies.” The Journal of Politics 59(2): 418-451.

Munck, Gerardo L. 2001. “The Regime Question: Theory Building in Democracy Studies.” World Politics 54(1): 119-144.

Oneal, John R. and Bruce M. Russett. 1997. "The Classical Liberals Were Right:Democracy, Interdependence, and Conflict, 1950-1985.” International Studies Quarterly 41: 267-294.

Ottaway, Marina. 2003. Democracy Challenged: The Rise of Semi-Authoritarianism.” Washington, D.C.: Carnegie Endowment for International Peace.

Pharr, Susan J. 2000. “A Quarter-Century of Declining Confidence.” Journal of Democracy 11(2): 5-25.

Plattner, Marc F. and Joao Carlos Espada, eds. 2000. The Democratic Invention.Baltimore: Johns Hopkins UP.

Plattner, Marc F. and Larry Diamond. 1995. “Democracy’s Future.” Journal of Democracy 6(1): 3-6. 
Preworski, Adam, Michael Alvarez, Jose Antonio Cheibub, Fernando Limongi. 2000. Democracy and Development: Political Institutions and Well-Being in the World, 1950-1990. New York: Cambridge UP.

Preworski, Adam, Michael Alvarez, Jose Antonio Cheibub, Fernando Limongi. 1996. “What Makes Democracies Endure?” Journal of Democracy 7(1): 39-55.

Pridham, Geoffrey and Paul G. Lewis, eds.. 1996. Stabilising Fragile Democracies: Comparing New Party Systems and Eastern Europe. New York: Routledge.

Rae, Douglas W. 1971. "Political Democracy as a Property of Political Institutions." American Political Science Review 65(1): 111-119.

Ragin, Charles C. and Howard S. Becker. 1992. What is a Case? Exploring the Foundations of Social Inquiry. New York: Cambridge UP.

Remmer, Karen. 1997. "Theoretical Decay and Theoretical Development: The Resurgence of Institutional Analysis.” World Politics 50(1): 34-61.

Reynolds, Andrew, ed. 2002. The Architecture of Democracy: Constitutional Design, Management, and Democracy. New York: Oxford UP.

Roberts, Kenneth M. 1996. "Neoliberalism and the Transformation of Populism in Latin America: The Peruvian Case.” World Politics 48(1): 82-116.

Rowen, Henry S. 1996. "The Tide Underneath the Third Wave." In The Global Resurgence of Democracy, $2^{\text {nd }}$ Edition. Larry Diamond and Marc F. Plattner. Baltimore: Johns Hopins UP.

Schedler, Andreas. 1998. “What is Democratic Consolidation?” Journal of Democracy 9(2): 91-107.

Scott, W. Richard. 1995. Institutions and Organizations. Thousand Oaks, CA: Sage.

Shapiro, Ian and Stephen Macedo. 2000. Designing Democratic Institutions. New York:New York UP.

Signorino, Curtis S. and Jeffery M. Ritter. 1999. "Tau-b or Not Tau-b: Measuring the Similarity of Foreign Policy Positions.” International Studies Quarterly 43:115144.

Simensen, Jarle. 1999. "Democracy and Globalization: Nineteen Eighty-nine and the 'Third Wave.’” Journal of World History 10(2): 391-411. 
Singer, J. David, Stuart Bremer, and John Stuckey. 1972. "Capability Distribution, Uncertainty, and Major Power War, 1820-1965." in Bruce Russett (ed) Peace, War, and Numbers, Beverly Hills: Sage, 19-48.

Snyder, Jack. 2000. From Voting to Violence: Democratization and Nationalist Conflict. New York: W.W. Norton and Company.

Snyder, Jack and Karen Ballentine. 1996. "Nationalism and the Marketplace of Ideas." International Security 21(2): 5-40.

Sorensen, Georg. 1998. Democracy and Democratization: Processes and Prospects in a Changing World, $2^{\text {nd }}$ Edition. Boulder, CO: Westview Press.

Soskice, David, Robert H. Bates, and David Epstein. 1992. “Ambition and Constraint: The Stabilizing Role of Institutions." Journal of Law, Economics, and Organizations 8(3): 547-60.

Spiro, David E. 1994. “The Insignificance of the Democratic Peace.” International Security 19(3): 50-86.

Stinnett, Douglas M., Jaroslav Tir, Philip Schafer, Paul F. Diehl, and Charles Gochman. 2002. “The Correlates of War Project Direct Contiguity Data, Version 3.” Conflict Management and Peace Science 19(2): 58-66.

Stromberg, Roland N. 1996. Democracy: A Short, Analytical History. New York: M.E. Sharpe.

Terchek, Ronald, and Thomas C. Conte, eds. 2001. Theories of Democracy. New York: Rowman and Littlefield.

Thompson, William R. and Richard Tucker. 1997. "A Tale of Two Democratic Peace Critiques.” Journal of Conflict Resolution 41(3): 428-454.

Thompson, William R. and Richard Tucker. 1997. "Bewitched, Bothered, and Bewildered: A Reply to Farber and Gowa and to Mansfield and Snyder.” Journal of Conflict Resolution 41(3): 462-477.

Thorsten Beck, George Clarke, Alberto Groff, Philip Keefer, and Patrick Walsh. 2001. "New tools in comparative political economy: The Database of Political Institutions." World Bank Economic Review 15(1): 165-176.

United Nations Development Programme. 2000. Human Development Report. http://www.undp.org/hdro/

Van Belle, Douglas A.2000. Press Freedom and Global Politics. Westport, CT: Praeger. 
Van Belle, Douglas A. 1997. "Press Freedom and the Democratic Peace." Journal ofPeace Research 34(4): 405-414.

Varshney, Ashutosh. 1998. "Why Democracy Survives.” Journal of Democracy 9(3): 3650.

Wagenaar, Hendrik. 2000. Government Institutions: Effects, Changes, and Normative Foundations. Boston: Kluwer Academic Publishers.

Ward, Michael D., and Kristian S. Gleditsch. 1998. "Democratizing for Peace.” American Political Science Review (92(1): 51-61.

Warren, Mark E. 2001. Democracy and Association. Princeton, NJ: Princeton UP.

Weaver, R. Kent, and Bert A. Rockman. 1993. Do Institutions Matter? Government Capabilities in the United States and Abroad. Washington, D.C.: The Brookings Institution.

Weingast, Barry R. 1995. “The Economic Role of Political Institutions.” The Journal of Law, Economics, and Organizations 7(1): 1-31.

Whitehead, Laurence. 1999. "The Drama of Democratization.” Journal of Democracy 10(4): 84-98.

Wittman, Donald A. 1995. The Myth of Democratic Failure: Why Political Institutions Are Efficient. Chicago: The University of Chicago Press.

Wolf, Reinhard, Erich Weede, Andrew J. Enterline, Edward D. Mansfield, and Jack Snyder. 1996. "Correspondence: Democratization and the Danger of War." International Security 20(4): 176-207.

Zakaria, Fareed. 1997. “The Rise of Illiberal Democracies.” Foreign Affairs 76(6): 22-43. 